\title{
Rare and little-known ammonites from the Lower and Middle Jurassic of the Western and Central Balkan Mts (Bulgaria)
}

\section{Lubomir Metodiev}

Geological Institute, Bulgarian Academy of Sciences, Acad. G. Bonchev Str., Bl. 24, 1113 Sofia, Bulgaria; e-mail: lubo@geology.bas.bg

(Accepted in revised form: January 2019)

\begin{abstract}
This paper presents insufficiently or previously unknown Jurassic ammonites from 21 localities and sections of the Western and Central Balkan Mts (Bulgaria). The total stratigraphical range of the studied fauna corresponds to a broad interval, from the Pliensbachian (Lower Jurassic) to the Callovian (Middle Jurassic), with emphasis on the ammonites from the Bajocian-Callovian interval. These ammonites belong to 36 species and 23 genera that are affiliated to 12 ammonite families: Polymorphitidae, Acanthopleuroceratidae, Amaltheidae, Hildoceratidae, Graphoceratidae, Strigoceratidae, Sonniniidae, Stephanoceratidae, Oppeliidae, Tulitidae, Parkinsoniidae, and Perisphinctidae. Of them, 13 species have been left in open nomenclature. This account comprises both newly recorded ammonite taxa and redefined ammonite species from older collections. The new evidence also includes the upper Bathonian species Siemiradzkia mangoldi sp. n., which was recorded from south-eastern France as well. Although being represented mainly by single specimens, often with no other supporting material, the newly discovered taxa have high stratigraphical significance, being both valuable additions to well-known Bulgarian ammonite zonal associations and new indications of ammonite successions that have quite poorly been identified in Bulgaria to date. In this regard, they are useful for better dating of the sedimentary successions in Bulgaria and are valuable for the purposes of correlation outside Bulgaria.
\end{abstract}

Metodiev, L. 2019. Rare and little-known ammonites from the Lower and Middle Jurassic of the Western and Central Balkan Mts (Bulgaria). Geologica Balcanica 48 (1), 3-41.

Keywords: ammonites, Jurassic, Siemiradzkia mangoldi sp. n., Balkan Mts, Bulgaria.

\section{INTRODUCTION}

The sediments from the Western and Central Balkan Mts are the main source for the ammonites of the Jurassic of Bulgaria. Numerous publications over the last 120 years have been devoted to these fossils and have contributed with many species and genera, reported and described so far. This has led to gradual construction of a more or less detailed sequence of the ammonite associations for almost all of the eleven Jurassic stages in Bulgaria. Excluding the strata of the Hettangian and the Sinemurian, where ammonites are, as a rule, extremely rare, the rocks corresponding to the remaining Jurassic stages have relatively well-defined ammonite successions, due to the more regular occurrence of ammonite faunas. Nevertheless, there remain numerous points of correlation to be settled and decisions on taxonomic definitions to be agreed upon. Besides, the ongoing collecting activities often yield rare or little-known taxa from the strata, such as those of the Pliensbachian and the Aalenian, and especially of the Bajocian, the Bathonian, and the Callovian. Also, reviews of the available older collections often give evidence for the presence of insufficiently known ammonite taxa. This group includes numerous species already discovered by previous workers, but many of them have so far only been indicated in faunal lists or have not been published at all. Both the newer and the older records often contribute with stratigraphically significant taxa and, therefore, add more to what has been known until now. The purpose of the present paper is to provide new information on ammonites from the Lower and 
the Middle Jurassic, based on both newly obtained specimens and revision of older Bulgarian material.

\section{GEOLOGICAL BACKGROUND, LOCALITIES AND MATERIAL}

According to their position in the framework of the Balkan orogen in Bulgaria, the main occurrence of Jurassic outcrops corresponds to the Balkan and the Srednogorie zones (see Fig. 1). The general lithostratigraphy of these exposures was summarized by Sapunov and Metodiev (2007a). By far, the most important regions in regard to ammonite biostratigraphy are those of the Western and Central Balkan units, as well as those of the western Srednogorie Zone that geographically correspond to the Western and Central Balkan Mts. Outside these regions, ammonites are usually rare or even virtually absent in the rocks, and the outcrops have added nothing or little important to what is known from the Balkan Mts to date. This is due to either the distribution of lithologies unfavourable for ammonite preservation or the presence of common non-sequences in the overall sedimentary record. The deep subsurface occurrence of Jurassic rocks of the Balkan Zone, as well as those to the north, in the scope of the Moesian Platform, have been proved over the years to be often ammonite-bearing, but the ammonites tend to be fixed in widely separated faunal horizons, so that the exact temporal relationships between them may not be as certain as in the outcrops of the Balkan Mts. The known assemblages are notably fewer in numbers and many of the ammonites known from the exposures have not yet been found. Nevertheless, the ammonites of the borehole sections provide valuable additional evidence that can be associated with that of the outcrops.

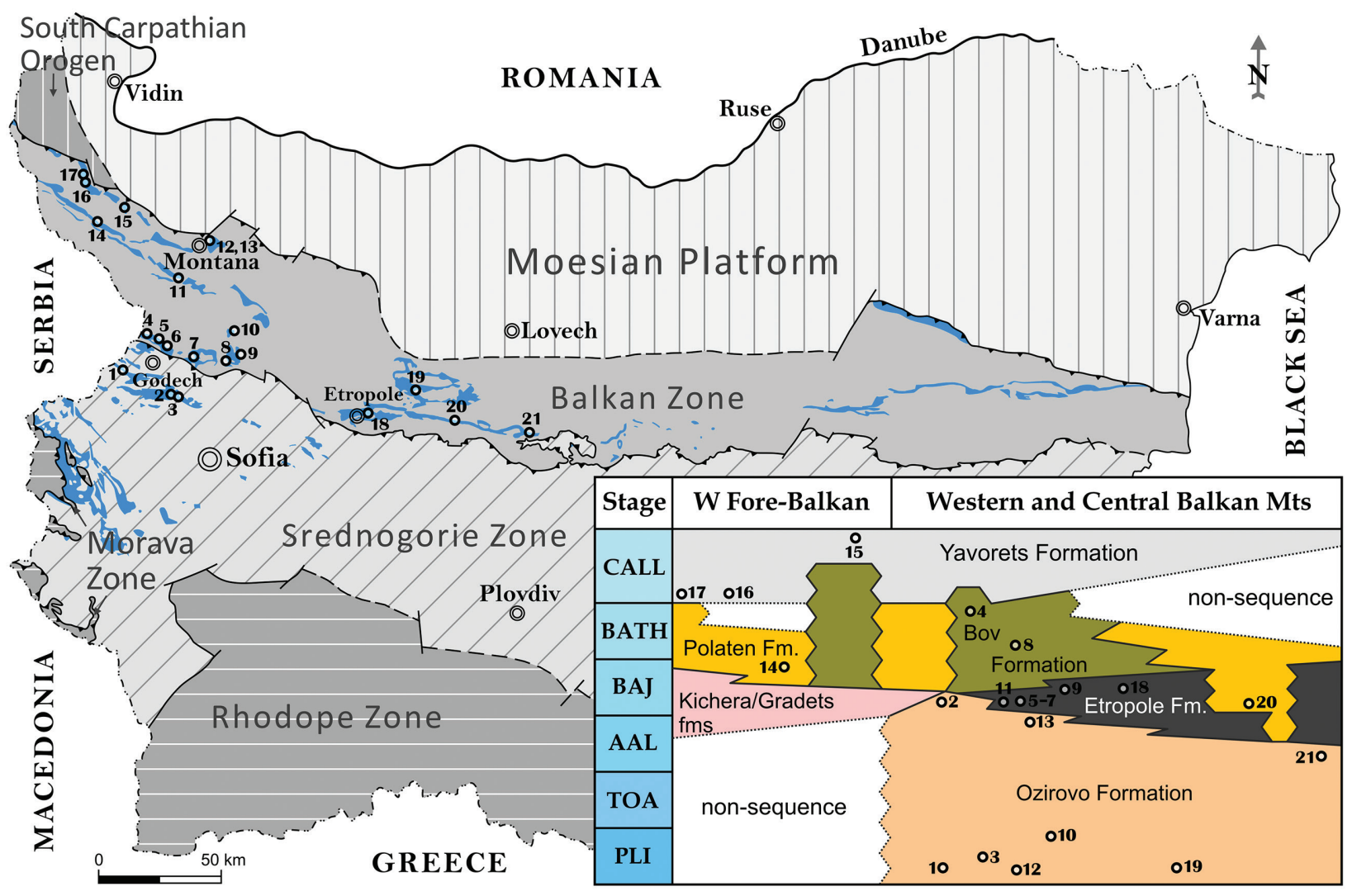

Fig. 1. Outcrops of the Jurassic rocks (blue) on the simplified tectonic map of Bulgaria (after Sapunov and Metodiev, 2007; Dabovski et al., 2002). The localities and sections that yielded the ammonites for this study are marked by a dot and a number: 1 - Vradlovtsi; 2 - Beledie Han; 3 - Dragovishtitsa; 4 - Komshtitsa; 5 - Gubesh; 6 - Gintsi; 7 - Dobravitsa; 8 - Bov; 9 - Izdremets; 10 - Milanovo; 11 - Gaganitsa; 12 - Borehole section C-3 Belotintsi; 13 - Borehole section R-1 Belotintsi; 14 - Dolni Lom; 15 - Nechinska Bara; 16 - Belogradchik-Gara Oreshets; 17 - Granitovo; 18 - Etropole; 19 - Teteven; 20 - Chernata Reka; 21 Brusovete. The inset schematic diagram represents the approximate positions of ammonite-bearing levels within the stratigraphic occurrence of the rocks, from which the ammonites were collected (local intraformational gaps are not shown). Abbreviations: PLI - Pliensbachian; TOA - Toarcian; AAL - Aalenian; BAJ - Bajocian; BATH - Bathonian; CALL - Callovian. 
Overall, the Jurassic ammonite-bearing deposits in Bulgaria refer to shallow-marine to moderately deeper-marine siliciclastic and carbonate rocks. For the Lower and the Middle Jurassic, most important, in terms of ammonite contents, are the sedimentary successions that refer to the following lithostratigraphic units: 1) the Ozirovo Formation (homogeneous or divided into members); 2) the Etropole Formation (homogeneous); 3) the Bov Formation (homogeneous or divided into members); 4) the Polaten Formation; and 5) the Yavorets Formation. Of them, twenty-one localities of the Western and Central Balkan Mts yielded the ammonites that are the focus of the present work (Table 1). Some of these are new or poorly known, with entirely new material, while others are known from older Bulgarian literature. Greater in number are the fields that include both previously published ammonites and unpublished specimens, which have either not been taken into account earlier or only recently been found.

\section{New and little-known ammonite localities of the Western Balkan Mts}

This group of ammonite fields refers to six outcrops and two borehole sections, which are exclusively located in the Western Balkan Mts. The oldest strata of this group correspond to the exposures of the Ravna Member and the Bukorovtsi Member of the Ozirovo Formation that crop out near the villages of Vradlovtsi and Milanovo (Sofia District), as well as to the deep borehole section C-3 Belotintsi, which is located near the town of Montana (see Fig. 1).

The locality Vradlovtsi represents the Ravna Member of the Ozirovo Formation, which is a regionally extensive shallow-marine sequence of early Sinemurian to early Pliensbachian age (Sapunov et al., 1976). It encompasses a 7-m thick succession of alternating sandy bioclastic limestones, calcareous sandstones and silty marlstones, with abundant bivalves and common brachiopods (Benatov, 1994). A level, located in the middle of the sequence, yielded a single specimen of Tropidoceras flandrini (Dumortier).

The locality Milanovo corresponds to a nearly 7.5-m thick succession of ferruginized silty marlstones, containing common phosphatic and pyrite nodules, rarely interbedded with thin iron ooidal-bioclastic limestones. It corresponds to the Bukorovtsi Member of the Ozirovo Formation and spans the upper Pliensbachian to the lower Bajocian. This field was noted in two previous works (Metodiev and Sapunov, 2001; Metodiev, 2008), in which some Toarcian and lower Bajocian ammonites were reported but without description of the entire sequence. A level particularly enriched in phosphatic nodules, positioned at $5 \mathrm{~m}$ above the base of the $\mathrm{Bu}$ korovtsi Member, yielded a single specimen of the upper Pliensbachian ammonite Pleuroceras solare (Phillips).

The C-3 Belotintsi borehole represents a 300-m thick section of the Ozirovo Formation, in which, at depth of $707 \mathrm{~m}$, a single Platypleuroceras brevispina (J. de C. Sowerby) has been found. It seems that this section corresponds to a thick sequence of the Dolni Lukovit and Bukorovtsi members of the Ozirovo Formation, which collectively span the Pliensbachian.

The next fields by age in this group are the borehole section R-1 Belotintsi, which is also located near the town of Montana, as well as the exposures of the Etropole Formation located near Gubesh Village and Izdremets Summit (Sofia District) (see Fig. 1). In borehole R-1 Belotintsi, at depths of 214-209 m, probably around the lithological transition between the Ozirovo and Etropole formations, three Aalenian ammonites were identified: Vacekia stephensi Buckman and Brasilia geisingensis Dietze et al. $[\mathrm{m}]$ and $[\mathrm{M}]$. Slightly younger than the rocks of this section are those of the localities near the village of Gubesh and Izdremets Summit. The former corresponds to a $10-\mathrm{m}$ thick lower Bajocian succession of shales of the Etropole Formation, in which fragmentary Witchellia and nuclei of Sonninia ammonites were found, along with a single Witchellia glauca Buckman. The locality at Izdremets Summit does not correspond to a specific exposure, but to a series of several closely located outcrops of the Etropole Formation, between Bov and Lakatnik villages, that yielded scattered Otoitidae and Sphaeroceratidae of the lower Bajocian (Metodiev, 2017), as well as a single Gerzenites postrugosus Westermann.

The youngest strata of this group are the outcrops of the Bov Formation, northeast of Komshtitsa Village (Sofia District), and the rocks of the Polaten Formation near Dolni Lom Village (Vidin District) (see Fig. 1). The former locality reveals a thin-bedded marlstone-limestone alternation, with scattered upper Bathonian ammonites, among which an example of Siemiradzkia mangoldi sp. n., herein introduced, was found. The Dolni Lom field was investigated in terms of its ammonite content by Sacharieva-Kowatcheva (1956), but a precise ammonite succession was not published. Perhaps, this locality also associates with the section of the so-called "Razhin Dol Formation" (a junior subjective synonym of the Polaten Formation), which was described by Tchoumatchenco (1977). The latter 
Table 1

Summary of data for the localities and sections that yielded the ammonites for this study

\begin{tabular}{|c|c|c|c|c|}
\hline $\begin{array}{l}\text { Locality/ } \\
\text { Section }\end{array}$ & $\begin{array}{l}\text { Lithostratigraphic } \\
\text { unit }\end{array}$ & Stratigraphic age & $\begin{array}{l}\text { Biostratigraphic age } \\
\text { constraint }\end{array}$ & References \\
\hline 1. Vradlovtsi & $\begin{array}{l}\text { Ravna Mb. } \\
\text { of the Ozirovo Fm. }\end{array}$ & $\begin{array}{l}\text { lower } \\
\text { Pliensbachian }\end{array}$ & Uptonia jamesoni Zone & Benatov (1994) \\
\hline 2. Beledie Han & Ozirovo Fm. & lower Bajocian & $\begin{array}{l}\text { Witchellia laeviuscula - } \\
\text { Otoites sauzei Zone }\end{array}$ & Sapunov (1969a) \\
\hline 3. Dragovishtitsa & Ozirovo Fm. & $\begin{array}{l}\text { lower } \\
\text { Pliensbachian }\end{array}$ & $\begin{array}{l}\text { Beaniceras luridum/ } \\
\text { Aegoce ras maculatum } \\
\text { zone boundary interval }\end{array}$ & Sapunov et al. (1976) \\
\hline 4. Komshtitsa & Bov Fm. & upper Bathonian & $\begin{array}{l}\text { Procerites hodsoni- } \\
\text { Clydoniceras discus Zone }\end{array}$ & this study \\
\hline 5. Gubesh & Etropole Fm. & lower Bajocian & $\begin{array}{l}\text { Witchellia laeviuscula } \\
\text { Zone }\end{array}$ & this study \\
\hline 6. Gintsi & Etropole Fm. & lower Bajocian & $\begin{array}{l}\text { Witchellia laeviuscula } \\
\text { Zone }\end{array}$ & Vrăbljanski et al. (1960) \\
\hline 7. Dobravitsa & Etropole Fm. & lower Bajocian & $\begin{array}{l}\text { Witchellia laeviuscula - } \\
\text { S. humphriesianum Zone }\end{array}$ & Metodiev et al. (2014) \\
\hline 8. Bov & Bov Fm. & $\begin{array}{l}\text { lower-middle } \\
\text { Bathonian }\end{array}$ & $\begin{array}{l}\text { Siemiradzkia repljanensis - } \\
\text { Procerites progracilis Zone }\end{array}$ & $\begin{array}{l}\text { Sapunov (1969b); Metodiev } \\
\text { and Sapunov (2017) }\end{array}$ \\
\hline 9. Izdremets & Etropole Fm. & lower Bajocian & $\begin{array}{l}\text { Stephanoceras humphrie- } \\
\text { sianum Zone }\end{array}$ & Metodiev (2017) \\
\hline 10. Milanovo & $\begin{array}{l}\text { Bukorovtsi Mb. } \\
\text { of the Ozirovo Fm. }\end{array}$ & $\begin{array}{l}\text { upper } \\
\text { Pliensbachian }\end{array}$ & Pleuroceras spinatum Zone & $\begin{array}{l}\text { Metodiev and Sapunov } \\
\text { (2001); Metodiev (2008) }\end{array}$ \\
\hline 11. Gaganitsa & Etropole Fm. & lower Bajocian & $\begin{array}{l}\text { Witchellia laeviuscula- } \\
\text { Otoites sauzei Zone }\end{array}$ & Nachev et al. (1963) \\
\hline $\begin{array}{l}\text { 12. Borehole section } \\
\text { C-3 Belotintsi }\end{array}$ & Ozirovo Fm. & $\begin{array}{l}\text { lower } \\
\text { Pliensbachian }\end{array}$ & Uptonia jamesoni Zone & this study \\
\hline $\begin{array}{l}\text { 13. Borehole section } \\
\text { R-1 Belotintsi }\end{array}$ & Ozirovo Fm. & Aalenian & $\begin{array}{l}\text { Brasilia bradfordensis } \\
\text { Zone }\end{array}$ & this study \\
\hline 14. Dolni Lom & Polaten Fm. & upper Bajocian & $\begin{array}{l}\text { Parkinsonia parkinsoni } \\
\text { Zone }\end{array}$ & $\begin{array}{l}\text { Sacharieva-Kowatcheva } \\
\text { (1956); Petrov (2005) }\end{array}$ \\
\hline 15. Nechinska Bara & Yavorets Fm. & upper Callovian & $\begin{array}{l}\text { Pseudopeltoceras spp. } \\
\text { Zone** }\end{array}$ & $\begin{array}{l}\text { Howarth and Stephanov } \\
\text { (1965); Metodiev and } \\
\text { Sapunov (2006); Metodiev } \\
\text { (2015) }\end{array}$ \\
\hline $\begin{array}{l}\text { 16. Belogradchik- } \\
\text { Gara Oreshets }\end{array}$ & Yavorets Fm. & lower Callovian & $\begin{array}{l}\text { Macrocephalites gracilis } \\
\text { Zone** }\end{array}$ & $\begin{array}{l}\text { Bončev and Popov (1935); } \\
\text { Stephanov (1961); } \\
\text { Petrov (2005) }\end{array}$ \\
\hline 17. Granitovo & Yavorets Fm. & lower Callovian & $\begin{array}{l}\text { Macrocephalites herveyi - } \\
\text { Macrocephalites gracilis } \\
\text { Zone** }\end{array}$ & $\begin{array}{l}\text { Sacharieva-Kowatcheva } \\
\text { (1956); Petrov (2005); } \\
\text { Metodiev (2015) }\end{array}$ \\
\hline 18. Etropole* & Etropole Fm. & lower Bajocian & $\begin{array}{l}\text { Witchellia laeviuscula - } \\
\text { Stephanoceras humphrie- } \\
\text { sianum Zones }\end{array}$ & $\begin{array}{l}\text { Kamenov (1936); Sapunov } \\
\text { (1961, 1963, 1971); Meto- } \\
\text { diev and Tsvetkova (2014) }\end{array}$ \\
\hline 19. Teteven & $\begin{array}{l}\text { Teteven Mb. } \\
\text { of the Ozirovo Fm. }\end{array}$ & $\begin{array}{l}\text { lower } \\
\text { Pliensbachian }\end{array}$ & Uptonia jamesoni Zone & Sapunov et al. (1971) \\
\hline 20. Chernata Reka & Polaten Fm. & lower Bajocian & $\begin{array}{l}\text { Witchellia laeviuscula- } \\
\text { Stephanoceras humphrie- } \\
\text { sianum Zone }\end{array}$ & $\begin{array}{l}\text { Sapunov and Tchouma- } \\
\text { tchenco, in: Cheshitev et } \\
\text { al. (1995) }\end{array}$ \\
\hline 21. Brusovete & Ozirovo Fm. & Aalenian & Leioceras opalinum Zone & $\begin{array}{l}\text { Sapunov (1968); Sapunov } \\
\text { et al. (1996); Metodiev } \\
\text { (2000) }\end{array}$ \\
\hline
\end{tabular}

The numbers of the sections and the localities are the same as on the map in Fig. 1, and the ammonites derived from them are shown in Figs 2-13; *The locality Etropole is a collective label for a few fields around the town of Etropole (for details, see below); **These zonal indices are still not in use in Bulgaria, but will be defined elsewhere. The rest of the zones adopted herein follow the labels from previous Bulgarian literature. 
author proposed a late Bajocian-middle Bathonian age for those rocks, mostly on the basis of diverse brachiopod faunas. The true succession and ages of this section still remain contradictory. Current information and a good log of the sequence can be found in Petrov (2005). A single upper Bajocian ammonite, identified as Lobosphinctes costulatosus (Buckman), was used for this study.

\section{Previously known ammonite localities of the Western and Central Balkan Mts}

This group of localities yielded both previously published and unpublished ammonites. It extends in occurrence into a wider geographic region, including the Western and the Central Balkan Mts (see Fig. 1). In terms of its total stratigraphical range, this group includes a broad interval, from the lower Pliensbachian to the upper Callovian. The youngest strata that supplied material for this study are those near the town of Teteven (Lovech District). These rocks represent a slice of an expanded Lower-Middle Jurassic sequence, studied in detail by Sapunov et al. (1971). In its lower part, in the Teteven Member of the Ozirovo Formation, a few specimens of the lower Pliensbachian ammonite species Uptonia bronni (Roemer) were collected. Similar age indication to that of the Teteven locality was obtained from the rocks that crop out near the village of Dragovishtitsa (Sofia District). They represent a thick section $(>30 \mathrm{~m})$ of the Ozirovo Formation that spans the entire Lower Jurassic and a part of the Middle Jurassic (Sapunov et al., 1976). The base of this sequence yielded a single specimen, tentatively defined as Fuciniceras ex gr. costicillatum (Fucini) - detractum (Fucini), which denotes Pliensbachian age. Comparable in lithology, thickness and stratigraphical extent to this section is the section near Beledie Han Village. It is better known in Bulgaria with its rich Toarcian ammonite faunas, but it also provides scattered Middle Jurassic ammonites (see Sapunov, 1969a; Sapunov et al., 1976), of which a single lower Bajocian Pelekodites moisyi (Brasil) falls within the scope of this study.

Almost identical in age, but contrastly differing from the Middle Jurassic strata of the localities Dragovishtitsa and Beledie Han, both in terms of facies and faunal concentration, are the ammonitebearing localities Gintsi, Gaganitsa, Dobravitsa and Etropole. These fields, which lithologically belong to the shales of the Etropole Formation, indicate different levels from almost the entire lower Bajocian.

The locality Gintsi (Sofia District) represents an eastwards lateral extension of the rocks from the above-mentioned locality Gubesh. It yielded a few ammonites of Witchellia pseudoromanoides Dietze, Chandler \& Schweigert and Witchellia cf. falcata Buckman, previously assigned by Vrăbljanski et al. (1960) to different species. The locality Gaganitsa (Montana District) corresponds to previously wellexposed, but now inaccessible, Lower-Middle Jurassic sequence (? >200 m thick) that was studied by Nachev et al. (1963). From it, the focus now is on several specimens of Pelekodites aurifer (Buckman) and Pelekodites nannomorphus (Buckman). The locality Dobravitsa is probably the best exposure of the Etropole Formation ( 90 m thick) in the Western Balkan Mts (Metodiev et al., 2014). It contributed with two specimens of Bradfordia (Iokastelia) costidensa Imlay and B. (I.) praeradiata (Douvillé) that have been reported but not illustrated before (Metodiev and Tsvetkova, 2014).

The Etropole locality encloses several closely related outcrops that compose the type-section for the Etropole Formation. As it has recently been pointed out (Metodiev and Tsvetkova, 2014), this is a repeatedly studied field, which persistently provides either new material or new data from previously collected specimens. From this locality, a collection of the following unknown and redefined ammonites is presented in this work: Witchellia laeviuscula (J. de C. Sowerby); W. patefactor (Buckman); Pelekodites moisyi (Brasil); P. aurifer (Buckman); Sonninia corrugata (J. de C. Sowerby); Sonninia ex gr. propinquans (Bayle); Sonninia aff. propinquans (Bayle); Epalxites anceps (Quenstedt); E. laticostatus Westermann; and Gerzenites postrugosus Westermann.

Eastwards, in the Teteven-Troyan region, the rocks of the Etropole Formation grade, both vertically and laterally, into the rocks of the Ozirovo and Polaten formations. Two fields of these lithostratigraphic units, namely the section Brusovete and the Chernata Reka locality, yielded ammonites. The Brusovete section has become known due to its rich Toarcian and Aalenian ammonite faunas (Sapunov, 1968; Sapunov et al., 1996; Metodiev, 2000). In this section, the topmost 3.5-m thick interval of the iron-bearing bioclastic limestones of the Ozirovo Formation yielded examples of the Aalenian species Csernyeiceras verpillierense (Roman \& Boyer). The locality Chernata Reka corresponds to lower levels of the Polaten Formation. A thin bed of ferruginized ooidal-bioclastic limestones was found to contain mixed Bajocian ammonite assemblage (Sapunov and Tchoumatchenco in: Cheshitev et al., 1995), of which an example of the lower Bajocian Witchellia aff. romanoides (Douvillé) is studied herein.

Going geographically much to the west of the last two fields, the remaining ammonite-bearing lo- 
calities included in this study correspond to the Bathonian and the Callovian. Arranged in ascending stratigraphic order, these localities are as follows: Bov, Granitovo, Belogradchik-Gara Oreshets, and Nechinska Bara.

The Bov locality (Sofia District) is the type-section for the Bov Formation. It was introduced by Sapunov (1969b), but merely as a rock sequence and without quoted faunas. Metodiev and Sapunov (2017) recently noted that the lower part of this sequence is particularly rich in lower and middle Bathonian ammonites. The assemblages still remain to be assessed from taxonomic viewpoint and only two examples, conditionally identified as Bullatimorphites? spp. [m], take part of the present account.

The Granitovo locality corresponds to a former limestone quarry, previously exploited for the production of rock fragments. This quarry, together with several outcrops NE of Granitovo Village (Vidin District), exposes a lithological succession ranging from the Kichera Formation (AalenianBajocian) to the Polaten and Yavorets formations (Bathonian-Callovian) (based on the observations of Sacharieva-Kowatcheva, 1956, with recently emended sequence by Petrov, 2005). A unique feature of this locality is the occurrence of a few meters thick beds of ferruginized bioclastic limestones (Polaten Formation, topmost middle Bathonian to upper Bathonian) and silty bioclastic limestones with indistinct nodular structure (the very base of the Yavorets Formation, lower-middle Callovian), which are especially rich in well-preserved and diverse ammonites, and have, therefore, attracted the attention of numerous collectors. Despite the key role of this locality, there is no full account on this site of crucial importance. The author of the present study has published a few short papers dealing with some of the ammonites from this site (Metodiev, 2015a, b; Metodiev 2016) but was unable to describe the sequence as, at present, no good exposures exist there. This work takes a notice of several species, such as Hemigarantia julii (d'Orbigny), Kheraiceras bullatus (d'Orbigny), and Homoeoplanulites ex gr. moorei (Oppel, in Neumayr), which have not been recorded elsewhere in Bulgaria to date.

The locality along the road between the town of Belogradchik and the Oreshets Railway Station (Vidin District) has acquired classical meaning due to the paper of Bončev and Popov (1935), in which the Callovian Stage was introduced in Bulgaria, based on the ammonite faunas from this site. The first subsequent revision of this field (Stephanov, 1961) revealed that it corresponds to two condensed beds: 1) fossil-bearing bed (45-cm thick) with lower Callovian ammonite assemblage; 2) 74-cm thick fossiliferous bed with lower Bathonian ammonites. From lithostratigraphic viewpoint, these two beds represent a parallel local unconformity between the Polaten and Yavorets formations (see also Petrov, 2005). The present work adds to the previous faunal lists of this locality an example of Alcidia mamertensis (Waagen).

The Nechinska Bara locality (Vidin District) is a continuous Middle Jurassic-Lower Cretaceous succession, in which the ammonite-rich Callovian strata first attracted the attention of Howarth and Stephanov (1965). These authors described a few rare ammonite taxa, provided the first log of the sequence, and opined that it is the best development of the Callovian in Bulgaria. Metodiev (2015b) presented a faunal list of recently discovered ammonites, with some details on the ammonites from the lower-middle Callovian interval. Herein, the emphasis is on the upper Callovian perisphinctids of three genera that have been found to occur into an 8-m thick interval of the Zubera Member of the Yavorets Formation (Metodiev and Sapunov, 2006). These ammonites are yet ambiguously identifiable but interpreted as follows: Binatisphinctes aff. binatus (Leckenby); Binatisphinctes cf. hamulatus (Buckman) [M]; Binatisphinctes ex gr. rjasanensis (Teisseyre); Binatisphinctes ex gr. rossicus (Siemiradzki); Choffatia poculum (Leckenby); Choffatia sp. cf. Choffatia trina (Buckman); and Alligaticeras aff. rotifer (Brown). A single oppeliid species assigned to Alcidia aperta (Spath) is also considered in this work.

\section{Material}

This study is based on 60 ammonites that are kept in two institutions. Thirty specimens, mostly collected in the early 1930s by Prof. Boyan Kamenov, as well as by Prof. Ivo Sapunov and July Stephanov (both in early 1950s), are housed at the University of Sofia. The rest of the collection is housed in the Geological Institute of the Bulgarian Academy of Sciences, and it consists of ammonites obtained in the 1970s by Dr Vladimir Shopov, as well as of ammonites recently collected by the author. Inventory numbers of the studied material have been abbreviated to letter-number codes, according to their repository: University of Sofia (Coll. Uni-Sofia) and Geological Institute (Coll. GI-BAS).

Depending on the lithologies of the host rocks, the ammonites described below display different degrees of preservation. They appear as external moulds or as phosphatized and ferruginized internal moulds, usually with well-preserved ornament, some of them fragmentary, but most of them with 
commonly preserved body-chambers and apertures. Ammonite specimens were figured mostly without additional treatment and in natural size, except for the larger specimens, which are at nearly $\times 0.8$ magnifications. An asterisk indicates end of the phragmocone. Where possible, specimens were labelled as [M] for macroconch dimorphs and [m] for microconchiate ammonites. Standard dimensions were measured and given in millimetres and as percentages of the diameter in the text, as well as in APPENDIX, as follows: $D$ (shell diameter), $W h$ (whorl height), $W b$ (whorl breadth), $U$ (umbilical width).

\section{Remarks on the ammonite faunas}

Attention should always be paid to the fact that ammonites generally have too an irregular occurrence in the Jurassic rocks in Bulgaria. They usually do not occur in abundance or, if abundant, occur in condensed beds where, in turn, precise biostratigraphical subdivisions are almost impossible. By far, the available records, including those of the present study, came from exposures that are both vertically and laterally isolated and separated by non-sequences. Consequently, the stratigraphical range of the identified taxa may have different degrees of accuracy. For these reasons, and since most of the recorded taxa are represented by only one or just a few specimens, the taxonomic determination and the age assessment of these species and genera are based on published morphospecies (and also morphogenera and subgenera) with better documented stratigraphical distribution (typically in NW Europe, but also in the Tethyan or Euroboreal areas) from outside Bulgaria. The scarcity of the ammonite taxa reveals that they presumably originate and evolve elsewhere. Perhaps, there were primary limitations in ammonite dispersal, as stated for instance by Dommergues et al. (1987). Nevertheless, the ammonites discussed herein seem to be good enough matches of the corresponding coeval taxa in Europe and, therefore, increase the faunal spectrum of the Bulgarian Lower and Middle Jurassic.

Following the systematics of Donovan et al. (1981) and Howarth (2013), the ammonites that are included in the present work were ascribed to twelve families. Some of the most interesting ammonites are described herein, but there are others that have not been included in this work and still await identification and description. Thus, the present record is confined to the following families: Polymorphitidae Haug, 1887; Acanthopleuroceratidae Arkell, 1950; Amaltheidae Hyatt, 1867; Hildoceratidae Hyatt, 1867; Graphoceratidae Buckman, 1905; Strigo- ceratidae Buckman, 1924; Sonniniidae Buckman, 1892; Stephanoceratidae Neumayr, 1875; Oppeliidae Douvillé, 1890; Tulitidae Buckman, 1921; Parkinsoniidae Buckman, 1920; and Perisphinctidae Steinmann, 1890. The former three of them are limited in distribution to the Lower Jurassic, and particularly to the Pliensbachian. The Hildoceratidae are well known in Bulgaria to be enclosed in range mainly in the Toarcian, but there are single specimens that represent the oldest and the youngest members of the family found so far, which were confined to the Pliensbachian and the Aalenian. The members of the remaining families range in the Middle Jurassic, most of which being allied to the Bajocian and the Callovian, and only a few ammonites were associated with the Bathonian.

\section{POLYMORPHITIDAE HAUG, 1887 AND ACANTHOPLEUROCERATIDAE ARKELL, 1950}

In Bulgaria, the members of these two families have been known so far as extreme rarities of the genera Tropidoceras, Acanthopleuroceras, Platypleuroceras, and Uptonia. By single specimens, these genera indicate a narrow interval of the lower Pliensbachian (see Sapunov and Metodiev, 2007b, and references therein) around the Uptonia jamesoni/Tragophylloceras ibex zones boundary interval (sensu Dommergues et al., 1997). In practice, both below and above this level, the earlier age assessments of the older and the younger strata available from the Bulgarian literature relied on the occurrence of bivalve and brachiopod taxa only. Interestingly, the present record confines to nearly the same level, although being from different fields and with different species as compared to those of the previous accounts. The new record is consistent with the discovery of three species: Platypleuroceras brevispina (J. de C. Sowerby), Tropidoceras flandrini (Dumortier), and Uptonia bronni (Roemer) (see Fig. 2).

\section{Platypleuroceras brevispina (J. de C. Sowerby)} (Fig. 2a)

This species was identified based on a single specimen containing the phragmocone and probably a part of the body-chamber. It is a medium-sized and evolute ammonite, bituberculate on the whorl sides. The ornament consists of simple, strong and regularly spaced ribs, which are straight, rectiradiate to prorsiradiate. Both inner and outer rows of tubercles occur throughout all ontogenetic stages. Dommergues (1987) discussed in detail the morphology and variability of this species and the Bulgarian ex- 


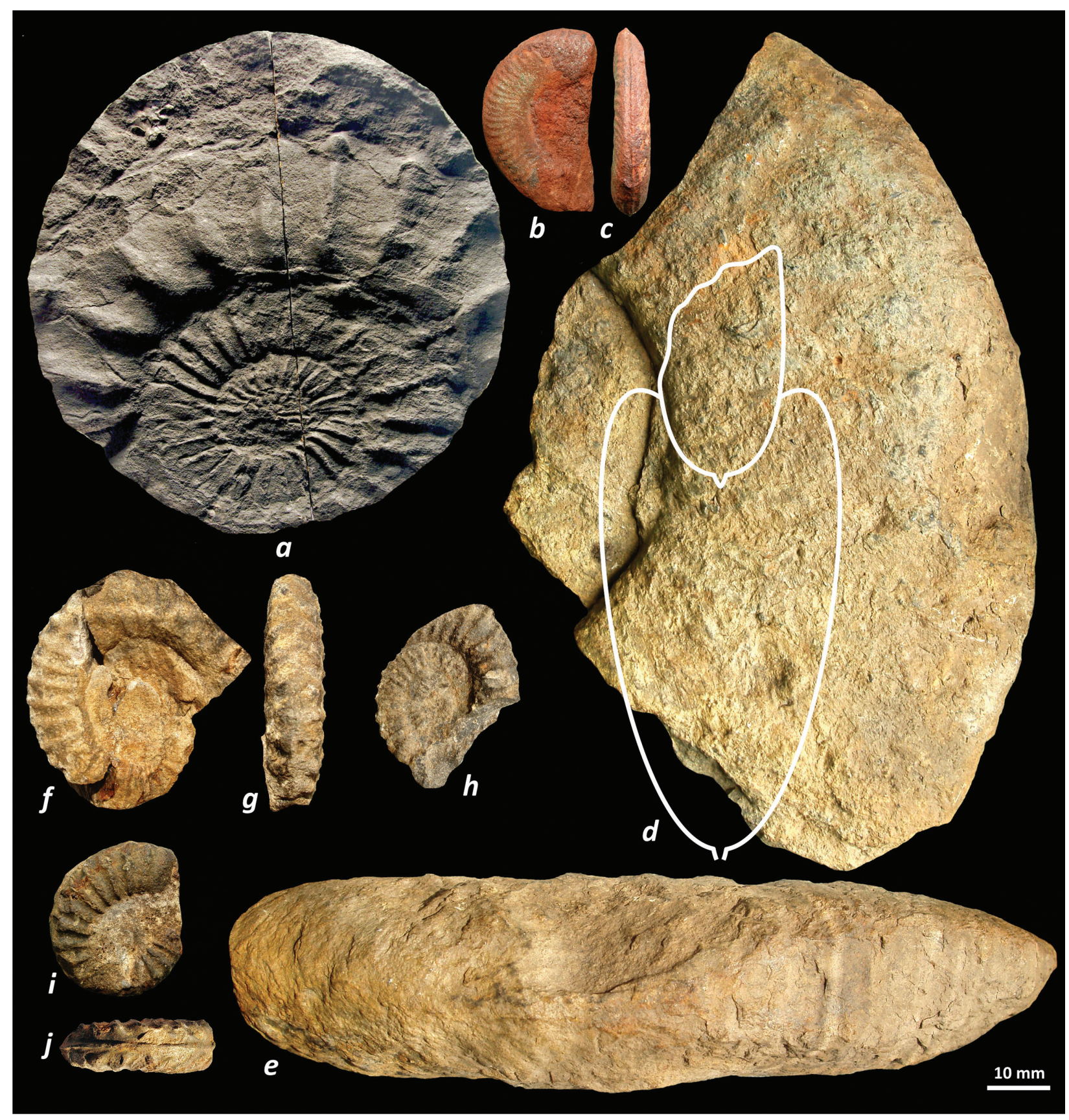

Fig. 2. Pliensbachian ammonites: a) Platypleuroceras brevispina (J. de C. Sowerby), borehole section C-3 Belotintsi (depth 707 m), Ozirovo Fm., lower Pliensbachian, Uptonia jamesoni Zone (Coll. Uni-Sofia, without inv. number); b, c) Fuciniceras ex gr. costicillatum (Fucini) - detractum (Fucini), section Dragovishtitsa (Ozirovo Fm., lowermost part), lower Pliensbachian, Beaniceras luridum/Aegoceras maculatum zones' boundary interval (Coll. GI-BAS, Inv.-Nr F.015824); d-e) Tropidoceras flandrini (Dumortier), locality Vradlovtsi (Ravna Mb. of the Ozirovo Fm., middle part), lower Pliensbachian, Uptonia jamesoni-Tragophylloceras ibex Zone (Coll. GI-BAS, Inv.-Nr F.015821); $f-h$ ) Uptonia bronni (Roemer), locality Teteven (Teteven Mb. of the Ozirovo Fm., type-section, middle part), lower Pliensbachian, Uptonia jamesoni Zone (Coll. GI-BAS, Inv.-Nrs F.015825, F.015826); i-j) Pleuroceras solare (Phillips), locality Milanovo (Bukorovtsi Mb. of the Ozirovo Fm., lower part), upper Pliensbachian, Pleuroceras spinatum Zone (Coll. GI-BAS, Inv.-Nr F.015827).

ample appears to be a good match of it. According to Meister and Friebe (2003), this species is well known from the Euroboreal regions and occurs sporadically in the areas of the northern Tethyan mar- gin. It typifies the 'Brevispina Horizon' (lower part of the P. brevispina Subzone) of the lower Pliensbachian Uptonia jamesoni Zone (see also Dommergues et al., 1997). 


\section{Tropidoceras flandrini (Dumortier)}

(Fig. 2d, e)

This species corresponds to a fragment of two whorls from the phragmocone of a large ammonite. It is moderately evolute and compressed, with high oval section and almost flat whorl sides, as well as with vertical to undercut umbilical walls and rounded venter. It seems to have had a strong keel, but the latter has been wiped because of either preservation or weathering. The smooth ribbing is falcoid and biplicate, broad and flat, showing differentiation into long primaries, short secondaries, and two or three intercalated ribs, the latter being developed in the ventro-lateral area. The inner preserved whorl does not seem to be tuberculate, but the outer one bears barely visible umbilical and ventro-lateral tubercles located at the points of bifurcation. According to Géczy and Meister (2007), T. flandrini is a widespread lower Pliensbachian species in both NW European and Tethyan regions, ranging from the uppermost Uptonia jamesoni Zone to the middle part of the Tragophylloceras ibex Zone (see also Dommergues et al., 1997).

\section{Uptonia bronni (Roemer)}

\section{(Fig. 2f-h)}

It corresponds to two incomplete specimens, at measured diameters of $39.5 \mathrm{~mm}$ and $28 \mathrm{~mm}$, probably showing only the inner whorls of the phragmocone. These ammonites are evolute and compressed, with subquadrate whorl sections and thin keel, bearing strong and rounded simple ribs that are moderately closely spaced. The ribs are slightly prorsiradiate and project forward on the ventro-lateral margin, bearing small tubercles and forming strong chevrons on the venter. As stated by Dommergues (1987), Meister and Böhm (1993), Fauré (2002), and Dommergues et al. (2008), Uptonia bronni is a microconch of Uptonia jamesoni (J. de C. Sowerby) that has a narrow stratigraphical distribution confined to the very top of the lower Pliensbachian Uptonia jamesoni Zone (see also Dommergues et al., 1997).

\section{AMALTHEIDAE HYATT, 1867}

The best, and so far the only one, paper devoted to this family in Bulgaria is that of Stephanov (1960). Based on the study of the ammonites collected from eleven localities of the Western and Central Balkan Mts, this author provided not only good definitions and detailed descriptions of ten species but also accurate data on their vertical distribution, on the basis of which he defined the upper Pliensbachian Amaltheus margaritatus and Pleuroceras spinatum zones in Bulgaria. From the time of this work to the present, no significant contributions have been made. Sapunov and Metodiev (2007b) summarized the stratigraphical significance of these faunas and refigured some of the ammonites from Stephanov's original paper.

\section{Pleuroceras solare (Phillips)}

(Fig. 2i-j)

Sapunov and Metodiev (2007b) found in the collection associated with Stephanov's (1960) paper a nice example of Pleuroceras solare (Phillips), which was identified and labelled by Stephanov himself, but has not been published. This ammonite was obtained probably from the upper levels of the Bukorovtsi Member of the Ozirovo Formation near Gintsi Village. It was measured and figured by Sapunov and Metodiev (2007b, Fig. 3r, s) and is most likely the first record of this species in Bulgaria. The present account makes available another example of the species, which seems to be exactly coeval with that of Stephanov's collection. The current record confines to a phosphatic internal mould of a phragmocone from the locality Milanovo (see above). This is a small planulate ammonite, with subquadrate whorl section, which is slightly higher than wide. The venter is tabulate, with strong serrated keel. Ribs are strong and radial, ending with ventro-lateral tubercles (see Fig. $2 i-j$ ).

Following Howarth (1958), Meister (1988), and Bardin et al. (2013), it became evident that, for both Pleuroceras solare and most amaltheids, too many specific names have been proposed in the past. These authors perfectly demonstrated that, if studying abundant and well-preserved collections from a single bed, a moderate amount of variation in rib strength and whorl proportion can be seen and, therefore, the bulk of the morphological types, for which these names have been proposed, refer in fact to a smaller number of species than previously thought. The Bulgarian material is quite inadequate in this respect, but the existing specimens appear to fall within the morphological limits adopted for Pleuroceras solare s.l. This gives reason to believe that the Bulgarian record is good enough to be added to the broad geographical dispersal of $P$. solare across Europe. From biostratigraphic viewpoint, the Bulgarian examples are indicative of the Pleuroceras apyrenum Subzone of the P. spinatum Zone in NW Europe (Dommergues et al., 1997). 


\section{HILDOCERATIDAE HYATT, 1867 AND GRAPHOCERATIDAE BUCKMAN, 1905}

In Bulgaria, hildoceratids are usually abundant in the Toarcian strata, where these ammonites can be found in large numbers. As their descendants, graphoceratids follow them vertically and define the sequences of the Aalenian Stage but decline around the Aalenian/Bajocian boundary interval. By far, and with just a few exceptions, the stratigraphical range of Hildoceratidae has been confined exclusively to the Toarcian. By chance, the present record extends the total vertical range of the family with documenting the earliest and the latest hildoceratid species, the Pliensbachian Fuciniceras ex gr. costicillatum (Fucini) - detractum (Fucini) and the Aalenian Vacekia stephensi Buckman. These taxa are temporarily abundant in western Tethyan localities (see Meister et al., 2011; Sandoval et al., 2012; Meister and Blau, 2014), but in Bulgaria they appear to be an absolute rarity. While the former taxon is represented by a single finding, the latter

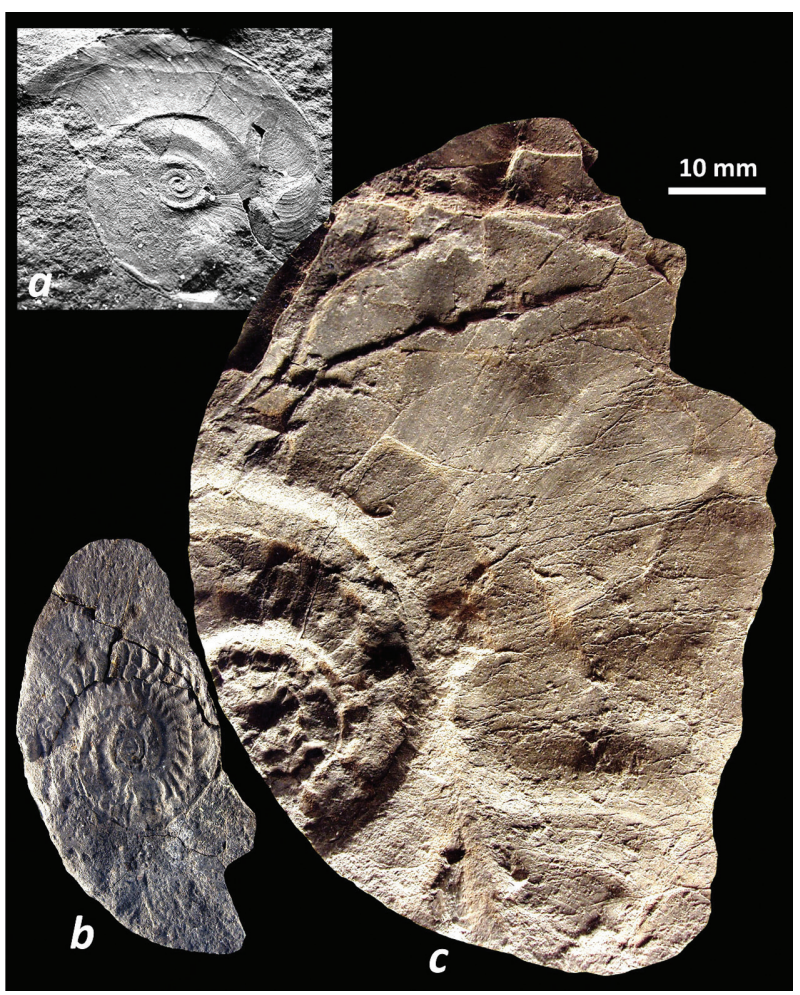

Fig. 3. Ammonites from borehole section R-1 Belotintsi (Aalenian, Brasilia bradfordensis Zone): a) Vacekia stephensi Buckman, Ozirovo Fm., depth 217 m (Coll. Uni-Sofia, without inv. number); b) Brasilia geisingensis Dietze et al. [m], Ozirovo Fm., depth 209 m (Coll. Uni-Sofia, without inv. number); c) Brasilia geisingensis Dietze et al. [M], Ozirovo Fm., depth 209-214 m (Coll. Uni-Sofia, without number). one is supported by the age-diagnostic Brasilia geisingensis Dietze et al. (see Figs 2, 3), which, in turn, is a graphoceratid with well-recorded stratigraphical position in SW Germany (Dietze et al., 2014).

\section{Fuciniceras ex gr. costicillatum (Fucini) - detractum (Fucini)}

(Fig. 2b, $c$ )

This name corresponds to a taxon complex, which includes coeval and closely similar Pliensbachian species that are still not specifically defined and separated and, as a result, have been left in open nomenclature (Meister et al., 2011). The present Bulgarian record consists of a small and half-preserved phragmocone, with diameter of $\sim 32.5 \mathrm{~mm}$. It is evolute and compressed, with flat whorl sides and flat venter, and there are ventro-lateral shoulders that border the keel. Ribs are fine and dense, falcoid and strongly projected forwards on approaching the venter. Although being incomplete, the Bulgarian specimen seems to be very similar to the ammonites from the eastern High Atlas (Morocco) recorded by Meister et al. (2011). Thus, it should be an indication of the lower Pliensbachian Tragophylloceras ibex/Prodactylioceras davoei zones' boundary interval (Dommergues et al., 1997), which in Bulgaria corresponds to the boundary interval between the local Beaniceras luridum and Aegoceras maculatum zones (Sapunov and Metodiev, 2007b). In the Subbetic Zone (Southern Spain), Braga (1983, p. 131, pl. 1, figs 1-5) recorded similar forms assigned to Fuciniceras portisi (Fucini) that have a narrow range and define a subzone at the very base of the upper Pliensbachian, i.e., the Portisi Subzone of the Lavinianum Zone (see also Braga, 1983, pp. 106-108, text-fig. 74), which, in turn, approximately corresponds to the lowermost Amaltheus margaritatus Zone (Amaltheus stokesi Subzone) in the scheme of Dommergues et al. (1997). Therefore, alternatively, the present specimen should possibly also be an indication of the local upper Pliensbachian Amaltheus stokesi Zone (sensu Sapunov and Metodiev, 2007b). However, the latter assumption is removed from consideration as the recorded ammonite was found in a level that certainly belongs to the lower Pliensbachian (see Sapunov et al., 1976, p. 105 - description of section Dragovishtitsa, Nos. 6-4; p. 123, fig. 3).

\section{Vacekia stephensi Buckman}

(Fig. 3a)

Vacekia stephensi is a well-known Aalenian species with well-documented distribution in England, 
Spain and Morocco (Sandoval et al., 2012), where it has been recorded in significant number of specimens. The present record refers to a single ammonite. This is small and involute ammonite with high elliptical whorls $(\mathrm{D}=37 \mathrm{~mm}$; U/D $=0.16$; Wh/D $=0.43)$. Umbilicus is minute, but inner whorls are clearly visible. The narrow venter holds a high and thin keel. The last preserved whorl, which probably contains part of the body-chamber, is ornamented by simple, flexuous and very fine weak ribs. According to Sandoval et al. (2012), Vacekia stephensi is affiliated to the Aalenian Ludwigia murchisonae and Brasilia bradfordensis zones. The Bulgarian example comes from an 18-m thick drilled borehole interval, in which specimens of the below described Brasilia geisingensis were also found. The latter species, together with Vacekia stephensi, are considered herein as indication of the Brasilia bradfordensis Zone.

\section{Brasilia geisingensis Dietze et al. [m] and [M]} (Fig. 3b, c)

It is a relatively new species, the distribution of which has been tied to a field from SW Germany (Dietze et al., 2014). The type locality yielded abundant material, with well-expressed dimorphism. The latter has been carefully documented in the German publication, introducing this and one more species of the genus Brasilia. A pair of dimorphs of Brasilia geisingensis, conveniently designated as microconch [m] and macroconch [M], takes part of the present Bulgarian record (see Fig. $3 b$ and Fig. $3 c$, respectively).

The microconch form is small and probably a nearly complete specimen, but without preserved aperture. It is moderately evolute and compressed, with steep umbilical walls and well-defined umbilical edge, and a narrow venter with moderately strong keel. Ribs are strong and falcoid, mostly bifurcate, and presumably persisting throughout the entire coiling.

The macroconch is a fragment of a medium-sized ammonite, from which part of the inner whorls with attached body-chamber are visible. It is also moderately evolute and compressed, with high and probably fastigate whorls. The relatively deep umbilicus is surrounded by steep umbilical walls, bordered by moderately angled umbilical edge. Flanks are slightly convex, probably preserved at about twothirds of the whorl height. The ornament seems to exist throughout. It is feeble on the last whorl and stronger on the inner whorls. Ribs are striate and rursiradiate on the curved umbilical wall, radial and gently curved backwards over the inner half of the whorl sides, then sweeping well forwards. A series of shallow undulating depressions seem to be regularly developed at mid-flanks.

The studied Bulgarian ammonites are very similar to some specimens of the German type-material. Particularly, the microconchiate form resembles the "less sculptured, slender variant" of Dietze et al. (2014, Fig. 4/1, 2), whereas the macroconch specimen resembles the "smooth variants of medium size" of Dietze et al. (ibid., Pl. 13). If these ammonites are truly in accordance with the German specimens, it means that a relatively thick development of the upper part of the Brasilia bradfordensis Zone does really exist in the Bulgarian succession. This is a curious fact, since this biostratigraphic unit in Bulgaria has been either recorded just in a condensed sequence or not recorded at all (see Metodiev, 2000).

\section{STRIGOCERATIDAE BUCKMAN, 1924}

In the original introduction of this ammonite family, eight genera were assigned to it by Buckman (1924), most of which proposed by Buckman himself. Of them, three emended genera have remained in the Treatise (Arkell et al., 1957, pp. L271-L272), namely, Praestrigites Buckman, 1924; Strigoceras Quenstedt, 1886; and Hebetoxyites Buckman, 1924. Both Buckman (1924) and Arkell et al. (1957) suggested that this family ranges throughout the Bajocian. In more recent times, Donovan et al. (1981) and Schweigert et al. (1999, 2003) attributed to the family additional ammonite genera, expanding in this way its total range from the Aalenian to the Oxfordian, and also opined that the family is derivative of some Aalenian Hammatoceratidae. These concepts are well known but nonetheless recalled herein, because in Bulgaria no strigoceratids, in the sense understood by both classical authors and their followers, has been found until now. The only Bulgarian record of this family is that of the genus Csernyeiceras Géczy, 1966. It has initially been attributed to Hammatoceratinae (Roman and Boyer, 1923; Géczy, 1966) but subsequently considered to have a strong link with and being a member of the family Strigoceratidae (see Galácz, 1980; Schweigert et al., 2000; see also Kovács, 2009).

The present paper is the first account on the presence of Csernyeiceras in Bulgaria (Fig. 4). It is based on previously recorded ammonites defined as "Hudlestonia sp. n." by Sapunov (1968) and now reinterpreted as Csernyeiceras verpillierense (Roman \& Boyer). This redefinition has become necessary since the genus Hudlestonia Buckman, 1980 is 


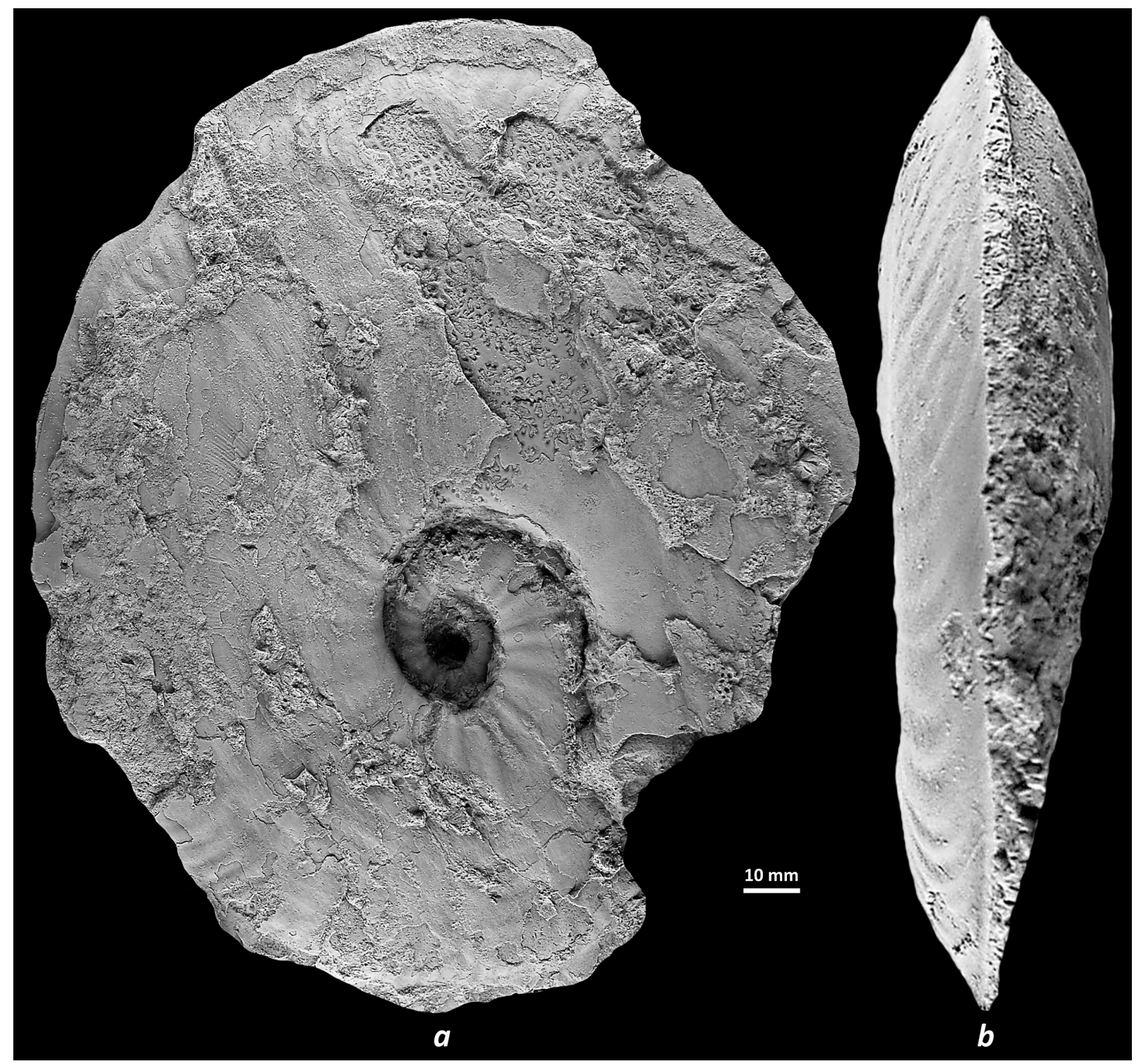

Fig. 4. Csernyeiceras verpillierense (Roman \& Boyer), specimen previously defined as "Hudlestonia sp. n." (Sapunov, 1968, p. 537), section Brusovete (Ozirovo Fm.), Aalenian, Leioceras opalinum Zone (Coll. Uni-Sofia, BAS J 104).

similar and probably allied somehow to Csernyeiceras, but it is confined to the upper Toarcian, without leaving descendants in younger strata, as stated by Rulleau (1993). Besides, the Bulgarian examples show good enough morphological features to be unambiguously attributed to Csernyeiceras verpillierense.

\section{Csernyeiceras verpillierense (Roman \& Boyer) (Fig. 4a, $b$ )}

The Bulgarian specimens of Csernyeiceras verpillierense are represented by two large phragmo- cones, one of which is figured herein. These ammonites are discoidal, compressed and fairly involute, with partly preserved test. The whorls are high, with slightly rounded whorl sides; the greatest whorl breadth is near the mid-flanks. The inner half of the whorl sides is slightly sloped to the umbilicus, while the outer half converges towards an acute venter with high and sharp hollow keel. The umbilical edge is rounded and the umbilical walls are steep to undercut. The umbilicus seems to be smaller in earlier growth stages where the whorls overlap each other, so that the umbilical walls of several successive whorls almost coincide. The um- 
bilicus widens rapidly on the last two whorls to become moderately opened. Suture-lines are partially discernible but appear to be very complex, highly incised and ornate. Whorls are ornamented with weak, broad and moderately distant biconcave ribs. Ribs are composed of short primaries, developed around the umbilical area, and weak secondaries. They bend forwards at mid-whorl and curve gently backwards on the outer half of the whorl sides, and finally swing forwards to reach the sides of the keel as striae. Where the test is preserved, the whorls are covered by fine and dense striations following ribshape. The last parts of the final whorls seem to be almost smooth.

Csernyeiceras verpillierense is an uncommonly recorded species of Tethyan affinity. It seems to have short stratigraphical distribution in the Aalenian: England (well dated to the lower Scissum Zone - Callomon and Chandler, 1994); Hungary (the very base of the Aalenian - Géczy, 1966); France (Comptum Subzone - Elmi and Mouterde, 1997; Rulleau et al., 2001); Morocco (Murchisonae Zone, Benshili, 1989). In Bulgaria, this species has been recorded in the Leioceras opalinum Zone (Sapunov, 1968; see also Sapunov et al., 1996; Metodiev, 2000).

\section{SONNINIIDAE BUCKMAN, 1892}

As stated by Dietze et al. (2007), the members of the family Sonniniidae are among the best-documented and longest-known Middle Jurassic ammonites in Europe. However, in Bulgaria in particular, the same does not hold true. Since these are biostratigraphically significant ammonites, the sonniniids often appeared at times in the past in the published Bulgarian faunal lists, but descriptions and figures are rare. The occurrence of sonniniids remains obscure and most of the earlier citations in Bulgarian literature seem to be misidentifications. There are also many ambiguities, due to the state of preservation of some of the specimens and the lack of adequate stratigraphical precision, that preclude from following any modern concept of classification (e.g., Morton, 1972; Chandler et al., 2006; Dietze et al., 2007, 2009, 2011). Nevertheless, from both the earlier and the newer records, it can be stated that the family Sonniniidae in Bulgaria can be roughly related to two main groups of morphogenera: Witchellia-Pelekodites and Sonninia. The former group presumably has a vertical range that corresponds to the Witchellia laeviuscula and Otoites sauzei zones, whereas the latter group has a prominent presence in the Otoites sauzei Zone of the lower Bajocian (see Metodiev and Tsvetkova, 2014). Both groups may have correlation value, but not enough material is yet available to characterize their ranges and variability.

\section{Witchellia-Pelekodites Group}

(Figs 5, 6)

The morphogenus Witchellia Buckman, 1889, as here understood, includes medium-sized, moderately involute and compressed ammonites with heightened whorls. Flanks are flat, umbilical walls are steep, vertical to undercut. Shouldered to fastigate venter has a prominent keel bordered by either slight sulcus or narrow smooth area on either side. Ribs are falcoid, usually biplicate. The ornament is faint and progressively weakens with growth, reducing to growth lines. The present record of Witchellia consists of six species (see Fig. 5). Of them, one ammonite seems to be a good match of the lectotype of Witchellia laeviuscula (J. de C. Sowerby), from Dundry, near Bristol, England [Fig. $5 a, b$; see also Chandler et al., 2006, fig. 4/1 - a grayscale reproduction of the original figure of Sowerby (1824, pl. 451, fig. 1); fig. $4 / 2 \mathrm{a}-\mathrm{c}-\mathrm{a}$ new photographic figure of the same specimen, kept in the Natural History Museum, London, Sowerby collection]. This ammonite is an older discovery, probably of Ivan Nachev, with not precisely known locality or level, but is the first figuration of this species from Bulgaria. It differs from Sowerby's original in being smaller and more compressed, but has the same characteristic ribbing style of three or four ribs bundled in the inner parts of the whorl sides around the umbilicus. Along with Witchellia laeviuscula, there are specimens with amended position, now identified as follows: 1) Witchellia pseudoromanoides Dietze, Chandler \& Schweigert (Fig. $5 c-e$ ), and 2) Witchellia cf. falcata Buckman (Fig. 5i, j) (non "W. liostraca Buckman” or "W. complanata Buckman”, Vrăbljanski et al., 1960); 3) Witchellia aff. romanoides (Douvillé) (Fig. 5f), a specimen that was recorded by Sapunov and Tchoumatchenco but not taken into account by Cheshitev et al. (1995); and 4) Witchellia patefactor (Buckman) (Fig. 5g, h), original specimen of Kamenov (1936, p. 95; pl. 3, fig. 4) defined as "Witchellia corrugata Sow.”.

The ammonites (1) in the list above do not correspond to the species to which they have been assigned, but are akin to the varieties of $W$. pseudoromanoides with stouter whorls and early smoothing of sculpture (see Dietze et al., 2003, pl. 2, fig. 2 and pl. 5, fig. 2). The same applies to specimen (2) from above, which is comparable to the inner whorls, before the beginning of the body-chamber, of Buck- 


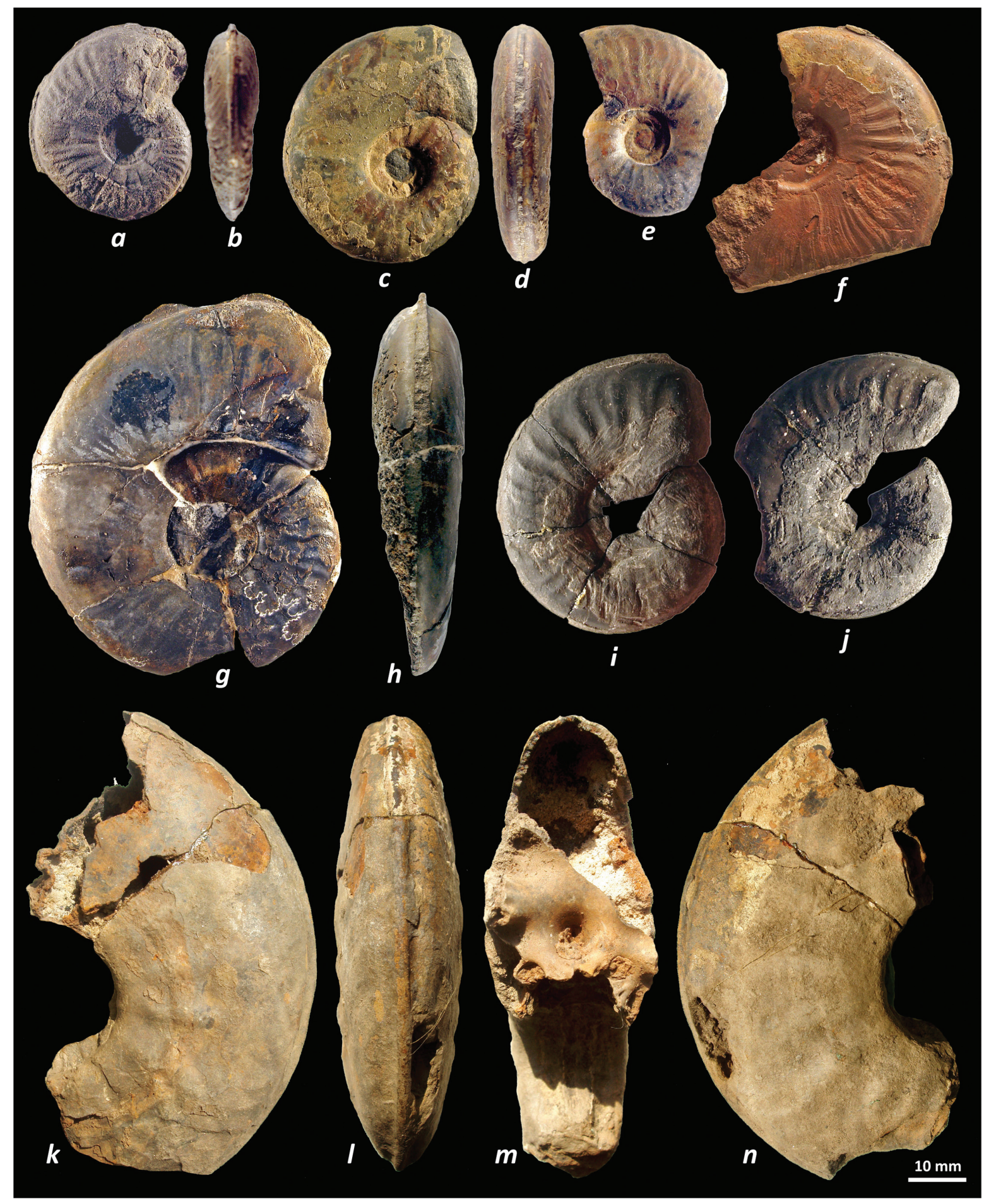

Fig. 5. Lower Bajocian ammonites from the Witchellia laeviuscula Zone: $a$, b) Witchellia laeviuscula (J. de C. Sowerby), from unspecified locality near the town of Etropole (probably from the valley of the Stara Reka River, south of Lopyan Village,), Stefanets Mb. of the Etropole Fm. (Coll. Uni-Sofia, without inv. number); $c$, d) Witchellia pseudoromanoides Dietze, Chandler \& Schweigert, specimen probably corresponding to the identification “Witchellia complanata Buckm.” of Vrăbljanski et al. (1960), locality to the west of Gintsi Village, Etropole Fm. (Coll. Uni-Sofia, without inv. number); e) Witchellia pseudoromanoides Dietze, Chandler \& Schweigert, from the same locality as $c$, $d$ (Coll. Uni-Sofia, without inv. number); $f$ ) Witchellia aff. romanoides (Douvillé), locality Chernata Reka (Coll. Uni-Sofia, without inv. number); $g, h$ ) Witchellia patefactor (Buckman), original specimen of Kamenov (1936, p. 95; pl. 3, fig. 4) defined as “Witchellia corrugata Sow.”, locality near the town of Etropole, Etropole Fm. (Coll. Uni-Sofia, Museum exposition); $i, j$ ) Witchellia cf. falcata Buckman, specimens probably corresponding to the identification “Witchellia complanata Buckm.” of Vrăbljanski et al. (1960), locality to the west of Gintsi Village, Etropole Fm. (Coll. Uni-Sofia, without inv. number); $k-n$ ) Witchellia glauca Buckman, locality to the NW of Gubesh Village, Etropole Fm. (Coll. GI-BAS, Inv.Nr F.015823). 
man's holotype (Buckman, 1926, pl. 688). The specimen (3) is similar to the lectotype of Witchellia romanoides (Dietze et al., 2007, pl. 4, fig. 2 - designated lectotype, represented as a photo of a cast of the original specimen of Douvillé, 1885, pl. 3, fig. 4), but differs in being more involute and having somewhat different ribbing style. The specimen (4) is indeed Witchellia, but the species to which it was assigned is incorrect. Thus, it is now redefined as Witchellia patefactor, as being very similar to the holotype of this species (Buckman, 1923, pl. 410). Additionally to these taxa, there is an example of Witchellia glauca Buckman (Fig. $5 k-n$ ), which has been recently found. Although being incomplete, the latter specimen resembles, in ribbing and coiling, the holotype of the species (Buckman, 1925, pl. 594).

It should be noted that the above listed Bulgarian ammonites, assigned to Witchellia, display a random distribution, which is ineffective for biostratigraphic purposes. They are indicative of different faunal horizons of the Witchellia laeviuscula Zone, which is currently in use in the NW European scheme for the lower Bajocian (e.g., Callomon and Chandler, 1990; Rioult et al., 1997; Chandler et al., 2006). Hence, it can be assumed that this ammonite zone could be identified, if not full, at least with sufficient extent, but for now the $W$. laeviuscula Zone is only indicated and cannot be considered as a completely useful biostratigraphic unit of the lower Bajocian in Bulgaria.

The morphogenus Pelekodites Buckman, 1923 [m] includes small and evolute ammonites, with sub-quadrate to sub-rectangular whorl section, rounded umbilical edge and a tricarinate-bisulcate venter. Ribs are strong, sinuous to biconcave, mostly bifurcating near the umbilical edge, but simple ribs also occur. Usually, ribs have thickened periumbilical stem and ventrolateral end. The strength of ribbing decreases at the end of the body-chamber and ribs become weak near the peristome. The latter usually has spatulate lappets. The present record consists of five specimens, assigned to three species: Pelekodites moisyi (Brasil), P. aurifer (Buckman), and P. nannomorphus (Buckman) (Fig. 6).

Pelekodites moisyi (Brasil) is a species already established in Bulgaria (Metodiev and Tsvetkova, 2014). Here, this taxon is represented by two specimens. The first of them (Fig. 6a, $b$ ) is an almost exact match and probably comes from the same level as the ammonite described and figured by Metodiev and Tsvetkova (2014, p. 34, figs 3.9-3.10). This is an original specimen of Kamenov (1936, p. 94; pl. 3, fig. 2) defined as "Witchellia pinguis Roem." from the locality St Iliya near the town of Etropole, probably associated with Otoites sauzei Zone. It is placed now in Pelekodites as both the whorl section and the ribbing style fall outside those adopted for Witchellia. On the other hand, "pinguis" is a species with similar morphology to P. moisyi, but it is of higher stratigraphical occurrence (in the Stephanoceras humphriesianum Zone) and with unclear generic affiliation that remains to be resolved (see Morton, 1972; Dietze et al., 2003, 2011). The second specimen of $P$. moisyi figured herein (Fig. $6 c, d$ ) comes from the locality Beledie Han and was interpreted as a Sonninia

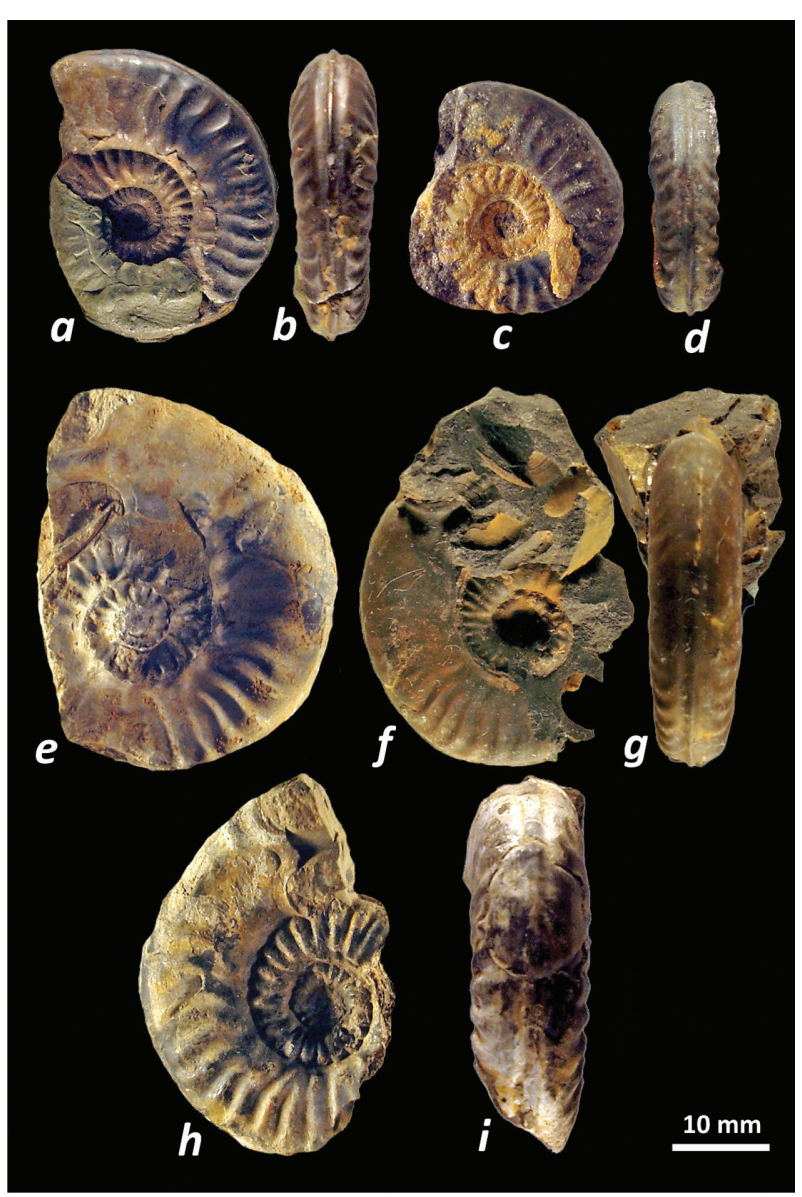

Fig. 6. Lower Bajocian ammonites from the Witchellia laeviuscula and Otoites sauzei zones: $a, b)$ Pelekodites moisyi (Brasil), original specimen of Kamenov (1936, p. 94; pl. 3, fig. 2) defined as "Witchellia pinguis Roem.", locality near the town of Etropole, Etropole Fm. (Coll. Uni-Sofia, Museum exposition); c, d) Pelekodites moisyi (Brasil), locality Beledie Han, Ozirovo Fm., (Coll. Uni-Sofia, BAS J 5860); e) Pelekodites aurifer (Buckman), original specimen of Nachev et al. (1963, p. 110) defined as "Witchellia deltafalcata (Quenstedt)", section Gaganitsa, Etropole Fm. (Coll. Uni-Sofia, BAS J 738); f, g) Pelekodites aurifer (Buckman), original specimen of Kamenov (1936, p. 94) defined as "Witchellia deltafalcata Quenstedt", locality near the town of Etropole, Etropole Fm. (Coll. UniSofia, without inv. number); $h-i)$ Pelekodites nannomorphus (Buckman), original specimen of Nachev et al. (1963, p. 110) defined as "Witchellia deltafalcata (Quenstedt)", section Gaganitsa, Etropole Fm. (Coll. Uni-Sofia, BAS J 737). 
nucleus from the Otoites sauzei Zone by Sapunov (1969a). However, this form lacks the typical whorl shape and ribbing of Sonninia and bears considerable resemblance to both the ammonite of Metodiev and Tsvetkova (2014) and that of Kamenov (1936), and for that is reinterpreted as $P$. moisyi.

Pelekodites aurifer (Buckman) and Pelekodites nannomorphus (Buckman) are based on three wellpreserved ammonites from two different localities, which were previously reported as "Witchellia deltafalcata (Quenstedt)” by Nachev et al. (1963, p. 110) (see Fig. 6e, $h-i$ ) and Kamenov (1936, p. 94) (see Fig. 6f, g). As previously discussed by Metodiev and Tsvetkova (2014, p. 35), Nannina deltafalcata (Quenstedt) really exists in the Bulgarian lower Bajocian ammonite record, but it was clearly assigned to the Stephanoceras humphriesianum Zone, while these specimens were recorded from older strata. Besides, the ammonites of Nachev et al., reproduced herein in Fig. $6 e, h-i$, could be closely matched with the holotype of Pelekodites aurifer (Buckman, 1928, pl. 766) and the holotype of Nannoceras nannomorphus (Buckman, 1923, pl. 467), correspondingly.

\section{Sonninia Group}

(Fig. 7)

Sandoval and Chandler (2000), Rulleau (2011), and Dietze et al. $(2005,2009)$ studied the ammonites of this group in great detail. These works demonstrated that Sonninia forms possess significant morphological variability and, if they are not based on material with exact stratigraphy, their proper interpretation would be very difficult. Although being mostly conditionally identified and in all cases without clear information on their stratigraphy, the specimens from the present study are still informative since data on these sonniniids in Bulgaria are highly incomplete. Of them, three specimens of strongly sculptured ammonites were identified as Sonninia corrugata (J. de C. Sowerby); a half-inner whorl with a huge mid-lateral spine was determined as Sonninia ex gr. propinquans (Bayle); and a near-complete tuberculate specimen was conditionally recognized as Sonninia aff. propinquans (Bayle) (see Fig. 7).

Sonninia corrugata (J. de C. Sowerby) corresponds to small and moderately evolute ammonites that seem to be septate throughout (Fig. $7 a, b$ ), as well as to a half-preserved whorl, which is probably a fragment of the body-chamber (Fig. $7 c, d$ ). These forms represent a common element of the fossil-bearing nodules from the type-section for the Etropole Formation, associated with the $O$. sauzei Zone. In the innermost whorls (up to $10 \mathrm{~mm}$ in diameter), the whorl-section is oval, but it rapidly becomes rounded and sub-rectangular in course of the coiling. Oblique to almost vertical umbilical walls are surrounded by rounded umbilical edge. Whorl sides are either convex or almost flat, on earlier and later whorls, respectively. The ventral area is rounded to sub-tabulate, with a thin keel. On the inner

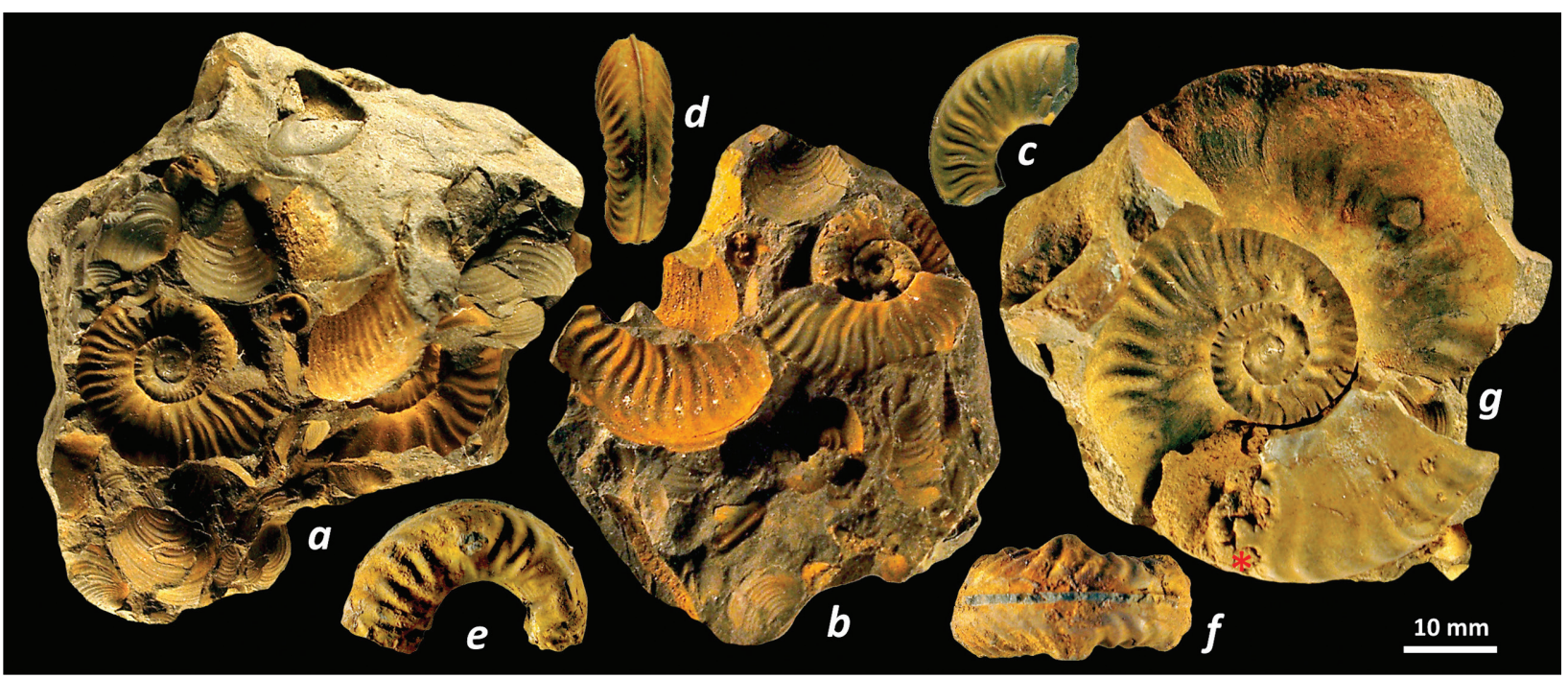

Fig. 7. Sonniniidae from the lower Bajocian of the Etropole Formation (Otoites sauzei Zone): $a$, $b$ ) Sonninia corrugata (J. de C. Sowerby), ammonites in a sideritic nodule containing abundant whole and crushed ammonites and 'Astarte' bivalves (Coll. UniSofia, without inv. number); $c$, d) Sonninia corrugata (J. de C. Sowerby), fragment of a body-chamber (Coll. Uni-Sofia, without inv. number); e, f) Sonninia ex gr. propinquans (Bayle), fragment of an internal whorl (Coll. Uni-Sofia, BAS J 5192); g) Sonninia aff. propinquans (Bayle), ammonite obtained from a sideritic nodule (Coll. Uni-Sofia, without inv. number). 
whorls, the ornament is fine and dense, consisting of sinuous ribs with small lateral tubercles that occur irregularly at every two to five ribs. On the outer whorls, the tubercles disappear. At these stages of coiling, the ribs are strong and falcoid, rarely single but mostly biplicate, usually bifurcating close to the umbilical area of the flanks. Studied ammonites are very similar to Ammonites corrugatus Sowerby (J. de C. Sowerby, 1824, pl. 451, fig. 3). However, as stated by Chandler et al. (2006), Sonninia corrugata (J. de C. Sowerby, 1824) is an often-cited species, but it was based on an inadequate nucleus and, therefore, must be judged nomen dubium. Therefore, this name may regain standing in ammonite taxonomy through study of type specimens or new material.

Sonninia ex gr. propinquans (Bayle) and Sonninia aff. propinquans (Bayle) correspond to a fragment of bigger evolute ammonite (a half-inner whorl at approximate diameter of $26.5 \mathrm{~mm}$ ), as well as to a specimen preserved as both a negative of the phragmocone and a mould of the body-chamber, in a siderite nodule. The former specimen (Fig. $7 e, f$ ) displays oval-subsquare section, with tabulate and slightly bisulcate venter that has a strong keel. It has strong and distant ornament that consists of short and distant, bifurcate falcoid ribs and well-developed lateral tubercles. The latter specimen (Fig. 7g) is a medium-sized and moderately evolute ammonite. Early whorls are rather depressed but whorl height gradually increases with growth and, in the last whorl, including both the last part of the phragmocone and the body-chamber, the whorl section becomes high and sub-rectangular. The sloping umbilical walls are surrounded by a rounded umbilical edge. Flanks are flat to slightly rounded. The venter is not clearly visible but seems to be sub-tabulate, with a slightly bisulcate keel. Ribbing persists throughout. On the inner whorls (up to $10 \mathrm{~mm}$ in diameter), ribs are dense and weak and every third or fourth rib bears tubercle, which lies against the dorsal wall of the next whorl. With the increase of the diameter, up to the end of the phragmocone, ribs become distant, strong and broad, falcoid in shape. Tubercles are displaced towards the umbilical area, supported by thick and short primary ribs and giving rise to two or three long secondaries; intercalatory ribs also occur, even though sporadically. This tuberculation appears regularly up to the last halfwhorl of the phragmocone. After that, tubercles gradually fade and disappear on the body-chamber. With the disappearance of the tuberculation, ribs become sinuous to biconcave. On the body-chamber, ribs are faint, far apart and striate.

Sonninia propinquans (Bayle) is a well-known classical species that denotes a standard ammo- nite zone in the lower Bajocian in NW Europe (see Rioult et al., 1997). In Bulgaria, it has recently been identified on good examples from the Otoites sauzei Zone, which is a local equivalent to the NW European S. propinquans Zone (Metodiev and Tsvetkova, 2014). Previously studied Bulgarian ammonites were found to be very similar in ornament and worl proportions to the lectotype (Waagenia propinguans Bayle, 1878, pl. 84, fig. 1) and several characteristic specimens from Germany and France (see Metodiev and Tsvetkova, 2014, pp. 31-32). By either the whorl proportions or the ornament, however, the present material is only tentatively attributable to $S$. propinquans. The specimen figured here in Fig. $7 e, f$ is comparable to the smaller paratypes published by Bayle (1878, pl. 84, figs 2-6), but differs in having a more depressed whorl section and more robust ribbing. Similar small and strongly sculptured forms have also been recorded in Scotland (Morton, 1975), France (Pavia, 1983) and Germany (Dietze et al., 2009), suggesting that this species may include ammonites of highly variable morphology. The specimen figured in Fig. $7 g$ displays typical ribbing for $S$. propinquans, but differs from the known specimens in the literature by being more evolute, with a lower whorl height and more pronounced tuberculation. By matrix and type of preservation, both of the ammonites presented herein are supposed to be from a level corresponding to the O. sauzei Zone.

\section{STEPHANOCERATIDAE NEUMAYR, 1875}

Stephanoceratids are relatively common in the lower Bajocian of Bulgaria. However, like most of the ammonite faunas of this interval, the members of this family display scattered distribution and have never appeared in significant numbers. Below are described microconchiate forms from both the Otoites sauzei and Stephanoceras humphriesianum zones that were referred to two morphogenera: Epalxites Mascke, 1907 and Gerzenites Westermann, 1954. Each of these genera is represented by a few specimens assigned to three species: Epalxites anceps (Quenstedt); E. laticostatus Westermann; and Gerzenites postrugosus Westermann (see Fig. 8).

\section{Epalxites anceps (Quenstedt)}

(Fig. 8a, b)

This species was defined on specimens having slightly more than three-quarters of a whorl, including the end of the phragmocone and the body-chamber, but the latter being without preserved aperture 


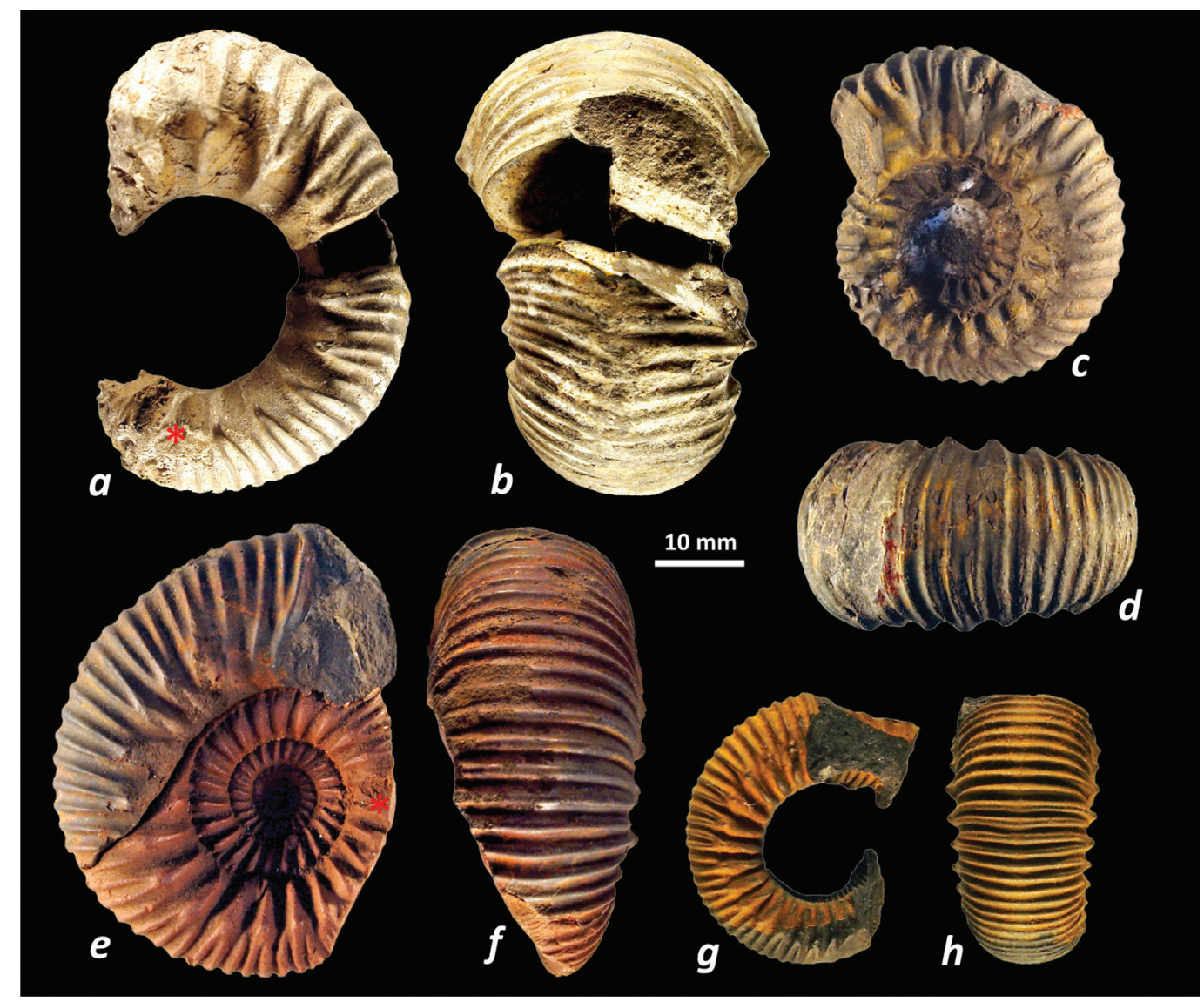

Fig. 8. Stephanoceratid microconchs from the lower Bajocian of the Etropole Formation (presumably from the Otoites sauzei and Stephanoceras humphriesianum zones): $a, b$ ) Epalxites anceps (Quenstedt), locality near the town of Etropole (Coll. Uni-Sofia, without inv. number); $c$, d) Epalxites laticostatus Westermann, original specimen of Kamenov (1936, p. 99) defined as "Teloceras parvum Weisert”, locality near the town of Etropole (Coll. Uni-Sofia, without inv. number); e, f) Gerzenites postrugosus Westermann, locality Izdremets (Coll. Uni-Sofia, without inv. number); $g, h$ ) Gerzenites postrugosus Westermann, locality near the town of Etropole (Coll. Uni-Sofia, without inv. number).

(see Fig. $8 a, b$ ). These ammonites are small and moderately evolute, with depressed whorl sections that broaden towards the end of the body-chamber. Venter is very wide and arched. The ornament is strong and sharp. It consists of short and distant primary ribs, which branch out into three or, more often, four ventro-lateral secondaries. There are small tubercles or spines at the points of rib furcation. The holotype for this species (Westermann, 1954, pl. 28 , figs $1 \mathrm{a}, \mathrm{b}$ ) is a distorted specimen, which makes it difficult to make comparisons. Even without inner whorls preserved, the Bulgarian examples of $E$. anceps fit well with the ammonites described and figured by Westermann (1954, pl. 27, figs 4a-c; pl. 28, figs. 2, 3) from Lauffen, near Göttingen (NW Germany). The latter came from the Otoites sauzei Zone. Their close resemblance to the Bulgarian specimens gives grounds to believe that, in Bulgaria, this species occurs on the $O$. sauzei Zone, too.

\section{Epalxites laticostatus Westermann}

(Fig. 8c, d)

Epalxites laticostatus is a reinterpreted species, based on specimens previously identified as "Teloceras parvum Weisert” (Kamenov, 1936, p. 99). It corresponds to small ammonites with deep and moderately opened umbilicus, fairly low and thick whorls. Ribbing is strong and sharp, developed throughout. On the inner whorls, ribs are straight and radial, and every rib bears one tubercle, which lies against the dorsal wall of the next whorl. These are primary ribs, for which, on the outermost whorl, it is seen that they branch into three to five ventrolateral secondaries. Tuberculation persists up to the last three quarters of the last preserved whorl. Perhaps, the last quarter of the outermost whorl represents the beginning of the body-chamber and, in this part, tuberculation abruptly ceases. Thus, 
adult features may be present. Although the bodychamber is not completely available, its aspect allows to assume that these ammonites are microconchiate forms and, therefore, cannot be referred to Teloceras, as previously thought. On the other hand, the Bulgarian specimens have enough similarity with both the holotype and the two paratypes figured by Westermann (1954, pl. 28, figs. 5a, b, and figs 6, 7). Compared to Epalxites anceps, the ammonites identified as E. laticostatus are less depressed, slightly more evolute, and with stronger and denser ornament. In terms of their stratigraphical position, these ammonites associate with strata older than the known occurrence of Teloceras and occur in levels that probably correspond to the boundary interval between the O. sauzei and the Stephanoceras humphriesianum zones.

\section{Gerzenites postrugosus Westermann}

(Fig. 8e-h)

This species was identified on a specimen with preserved inner whorls (Fig. $8 e, f$ ), as well as on small ammonites without preserved inner whorls (Fig. $8 g, h$ ). The whorls of the former specimen conform to the phragmocone and the beginning of the body-chamber, the latter being developed on the last three-quarters of the outermost whorl. The whorls of this example are depressed throughout and display ornament with strong sharpness and rib-density, which is composed of trifurcate tuberculate ribs. The incompletely preserved ammonites consist of three-quarter whorls that correspond to the body-chamber and that display a characteristic whorl contraction towards the outer end. The latter seems to mark the end of the body-chamber, but the aperture is not preserved. Whorl section is oval and depressed, with wide and arched venter and dorsum. Ribs are sharp and relatively dense, with deep intercostal intervals. They are composed of relatively long and concave primaries, which divide into two or three ventro-lateral secondaries. Small tubercles develop at the branching points. The Bulgarian examples display close morphological resemblance to the holotype for this species (Westermann, 1954, pl. 21, figs 2a-c), excluding the absence of the large lappets. Also, they are very similar to ammonites from the Chaudon section near Digne (SE France) that were described and figured by Pavia (1983, p. 139, pl. 26, figs $1-3,5,6)$. Gerzenites postrugosus was assigned by both Westermann (1954) and Pavia (1983) to the Stephanoceras humphriesianum Zone. Unfortunately, the Bulgarian material consists of loosely collected specimens and, therefore, their exact stratigraphical position is unknown.

\section{OPPELIIDAE DOUVILLÉ, 1890}

The members of the family Oppeliidae in Bulgaria refer to two main subfamilies: the Oppeliinae Bonarelli, 1894 and the Hecticoceratinae Spath, 1925. Of these, the Oppeliinae can be traced back to the ammonite genera Bradfordia Buckman, 1910 and Protoecotraustes Spath, 1928 in the Witchellia laeviuscula and Otoites sauzei zones of the lower Bajocian (see Sapunov, 1963; 1971; see also the comments given by Metodiev and Tsvetkova, 2014), then traced towards higher levels by the scattered occurrences of the genus Oppelia Waagen, 1869 (from the lower Bajocian Stephanoceras humphriesianum Zone to the upper Bajocian Parkinsonia parkinsoni Zone), and then, upwards, by the combined occurrence of the genera Oxycerites Rollier, 1909, OecotraustesWaagen, 1869, Paroecotraustes Spath, 1928, and Thraxites Stephanov, 1966, into the Bathonian (see Sacharieva-Kowatcheva, 1956; Sapunov and Stephanov, 1964; Stephanov, 1966; Metodiev et al., 2013; Metodiev and Sapunov, 2017). The highest record of Oppeliinae in Bulgaria is that of the genus Alcidia Rollier, 1913, which has recently been recorded by single specimens in the Callovian (Metodiev, 2015b). The ammonites included in this account were referred to taxa that were taken into account in the latest Bulgarian literature, but without being detailed. The figured examples, with the exception of Bradfordia (Iokastelia) praeradiata (Douvillé), correspond to species that have not been described and figured so far: Bradfordia (Iokastelia) costidensa Imlay, Alcidia mamertensis (Waagen), and Alcidia aperta (Spath) (Fig. 9).

\section{Bradfordia (Iokastelia) costidensa Imlay (Fig. 9a)}

Bradfordia (I.) costidensa conforms to a macroconch preserved as concretionary internal mould in a phosphatic nodule, from a level that associates with the boundary interval between the Otoites sauzei and Stephanoceras humphriesianum zones of the lower Bajocian. It is small and moderately involute, with typically high and elliptical whorl section that becomes broader at the body-chamber. Flanks are convex and smoothly passing into both the overhanging umbilical walls and the smooth, rounded venter. A narrow and shallow spiral furrow is developed close to the umbilical edge at the beginning of the last whorl, which corresponds almost entirely to the body-chamber. The most striking feature is the fine and dense ribbing. It consists of single and bundled ribs, weak to striate on the 


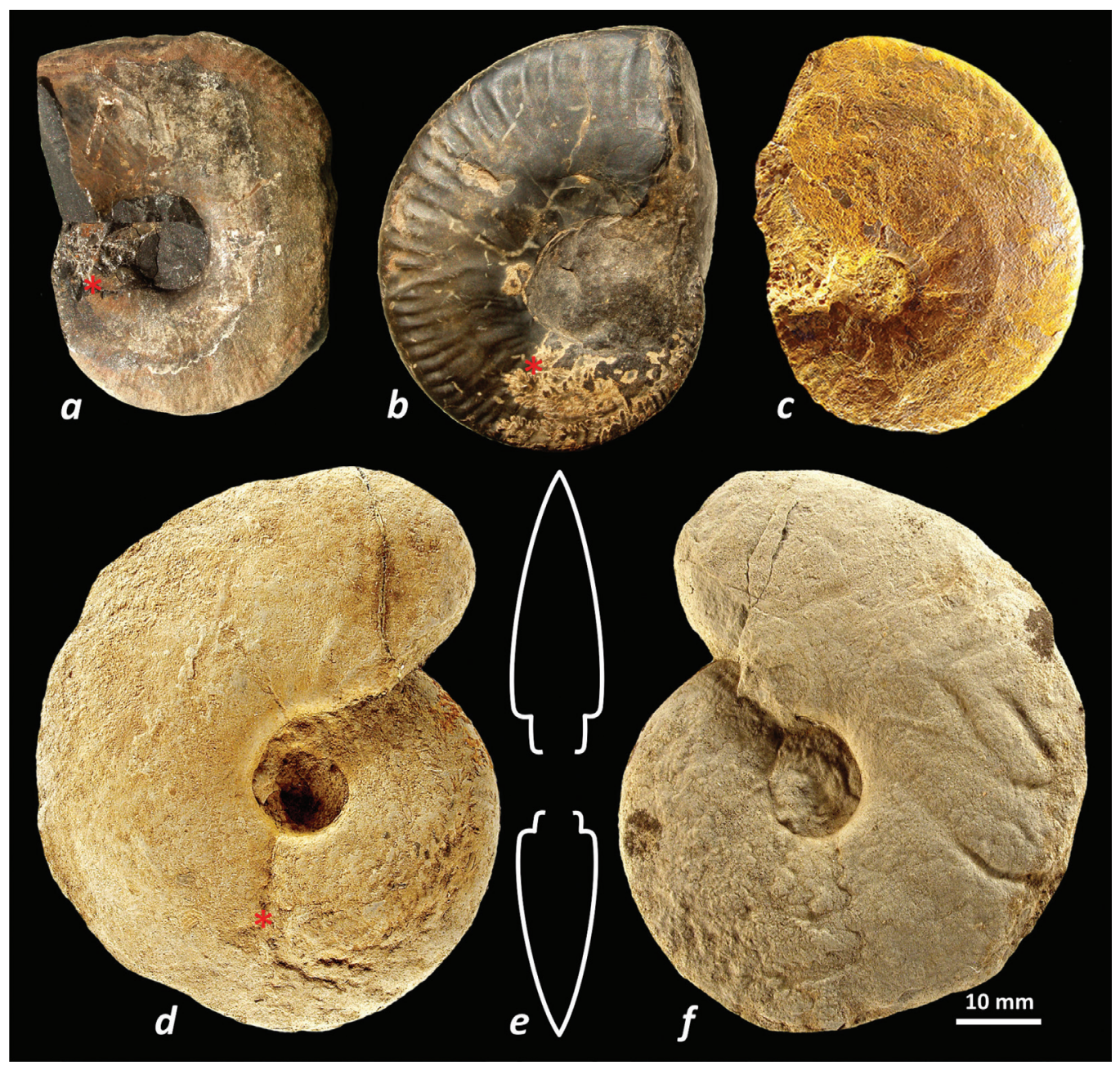

Fig. 9. Lower Bajocian and Callovian Oppeliidae: a) Bradfordia (Iokastelia) costidensa Imlay, locality Dobravitsa, Etropole Fm., topmost Otoites sauzei Zone - very base of Stephanoceras humphriesianum Zone (Coll. GI-BAS, Inv.-Nr F.015829); b) Bradfordia (Iokastelia) praeradiata (Douvillé), locality Dobravitsa, Etropole Fm., presumably from the Witchellia laeviuscula Zone (Coll. GI-BAS, Inv.-Nr F.015828); c) Alcidia mamertensis (Waagen), locality along the road between the town of Belogradchik and Gara Oreshets Railway Station, Yavorets Fm., Macrocephalites gracilis Zone (Coll. GI-BAS, Inv.-Nr F.002839); d-f) Alcidia aperta (Spath), section Nechinska Bara, Yavorets Fm., Pseudopeltoceras spp. Zone (Coll. GI-BAS, Inv.-Nr F.015835).

inner half of the whorl, stronger and more distant on the outer half, confined to the ventro-lateral shoulders. The dorsal half of each rib is prorsiradiate to slightly curved, concave forwards. Just before the middle of the whorl, ribs bend sharply backwards.

Figured specimen closely matches, and seems to be coeval with, the holotype for this species (Imlay, 1964, p. B39, pl. 8, figs 3-5; see also Westermann, 1992, pl. 28, figs 1a, b - refigured holotype). Also, it lies within the variability of Bradfordia costiden$s a$, as compared with most of the topotypes from the Talkeetna Mountains, Alaska (see Imlay, 1964, pl. 8, figs 1, 2; Imlay, 1984, pl. 1, figs 9-12). It seems that this species has a wider geographical dispersal and a longer range than originally thought. Except in North America, it was also recorded in Portugal and southern Spain, in the Aalenian Graphoceras concavum Zone (Henriques, 1995; Sandoval et al., 2001), as well as in the lower Bajocian Ovale Zone (possibly corresponding to the lower part of the W. laeviuscula Zone in Bulgaria) in Somerset, SW England (Dietze et al., 2007).

\section{Bradfordia (Iokastelia) praeradiata (Douvillé)}

(Fig. 9b)

Bradfordia (Iokastelia) praeradiata is a wellknown species in Bulgaria, described in detail by Sapunov (1971). A complete adult specimen with simple aperture is figured herein. This form shows appreciable morphological similarity to the lectotype for the species (Douvillé, 1884, pl. 3, fig. 7) 
in both coiling and style of ornament. Flanks are concave, with maximum whorl height in the dorsal area so that a funnel-shaped depression is formed around the umbilicus. The rib-shape is typically that of Bradfordia, i.e., straight to rursiradiate on the outer half of the whorl, where they either end abruptly at the edge of the venter or curve sharply forwards; ribs are weak or striate on the inner half of the whorl. The body-chamber corresponds to twothirds of the last whorl. At this stage of coiling, the whorl section transforms from compressed-elliptical to moderately compressed-rounded, sub-rectangular. Suture-line is highly incised and ornate, with many auxiliary saddles. Figured specimen is a concretionary internal mould from phosphatic nodule, with possible affiliation to the Witchellia laeviuscula Zone of the lower Bajocian.

\section{Alcidia mamertensis (Waagen)}

(Fig. 9c)

Alcidia mamertensis refers to a single specimen that was found during the revisional excavations of the classical locality along the road BelogradchikOreshets Railway Station in NW Bulgaria. This species was originally assigned to Oppelia by Waagen (1869) but later referred to Oxycerites by Elmi (1967). At the time of its discovery in Bulgaria, it was also treated as Oxycerites, but now it is assigned to the genus Alcidia Rollier, 1913 (pro Paralcidia Spath, 1928, Özdikmen, 2013), which is similar to both Oppelia and Oxycerites, but differs in being less involute and having sharper venter and weaker ornament. Figured Bulgarian specimen (Fig. 9c) is wholly septate, involute, compressed and feebly keeled, with distant prorsiradiate primary ribs and close, fine secondaries on the ventro-lateral edge that are slightly inclined backwards but curved forwards at the periphery. Every primary rib bears a characteristic, but less pronounced than usual, thickening at the inner part of the flanks. Mid-flanks are smooth, with a characteristic median-lateral spiral ledge that divides the whorl section into a concave dorsal half and a convex ventral half. Apparently, $P$. mamertensis is a rare species with remarkably low morphological variability, as evidenced by the specimens published in the literature which, despite being from different localities, are very similar to each other (e.g., Waagen, 1869, pl. 19, fig. 1; Petitclerc, 1915, pl. 3, figs 4, 5; Elmi, 1967, pl. 3, fig. 5; Rogov, 2004, pl. 1, figs 4, 5). Bulgarian example differs in having slightly less-narrow umbilicus and obliterated ornament, the latter due to the mode of preservation in leached internal mould. In terms of its stratigraphical position, this ammonite comes from a condensed assemblage that indicates the lower Callovian Macrocephalites gracilis Zone. In the localities outside Bulgaria, $P$. mamertensis was found in the upper parts of this zone, namely in the Ardescicum and Patina subzones (see Elmi, 1967; Rogov, 2004; see also Thierry et al., 1997).

\section{Alcidia aperta (Spath)}

(Fig. 9d-f)

This species was identified on a medium-sized, involute and compressed ammonite, which is almost smooth, with only a few weak, distant ribs visible. This is a typical oxycone, with small umbilicus and angled venter with feebly differentiated keel. Whorl section is narrow and triangular, and sides are only slightly rounded. The umbilical walls are undercut, with rounded umbilical edge. The last preserved whorl equally contains both the last part of the phragmocone and a part of the body-chamber. The specimen seems to be a fully-grown adult with maximum size attained, but the aperture is not preserved. The rare ribs are concave and inclined forwards, developed on the inner half of the sides. They resemble primary ribs, but secondaries are not observable. Suture line is characterized by great complexity. Excluding larger compression of the whorls, due to preservation in nodular limestones, the studied Bulgarian specimen has the same coiling as that of "Paralcidia khengari var. aperta" from the "upper 'athleta beds' = lamberti zone" at Fakirwady, Divesian (Spath, 1938, pl. 15, fig. 3). Besides, both the Bulgarian example and Spath's original display the same indistinct ornament. In addition, these ammonites seem to be closely coeval as being recorded from upper Callovian strata. The morphological and the stratigraphical similarities between these forms suggest that they may belong to a separate species, rather than to a morphological variety of other known species. On the other hand, the stratigraphic position of the Bulgarian ammonite can be assessed as not more accurate than the upper part of the upper Callovian. In Bulgaria, the Callovian remains yet poorly defined in terms of ammonite zonation and, at least for now, the strata from which Alcidia aperta was obtained are conditionally labelled as the Pseudopeltoceras spp. Zone. More details on the extent and the contents of this provisional and local biostratigraphic unit are given below, and its definition will be presented elsewhere.

\section{TULITIDAE BUCKMAN, 1921}

The Tulitidae are aberrant ammonites of characteristic cadicone to sphaerocone morphology, of- 
ten displaying various eccentricities of coiling and contracted body-chambers. This type of morphology suggests some specialization and somewhat confined (i.e., environmentally controlled) distribution of these forms, but they are nonetheless of wide dispersal (see discussion in Courville et al., 1999). In Bulgaria, the members of this family occur as rare stragglers in the rocks from the uppermost lower Bathonian to the lower Callovian. By far, the tulitids have been recorded by single specimens of scattered localities, referred to the ammonite genera Tulites Buckman, 1921, Rugiferites Buckman, 1921 and Bullatimorphites Buckman, 1921, of which a few taxa have been shown (Stephanov, 1963; Metodiev and Sapunov, 2017). The present account includes two ammonites tentatively interpreted as Bullatimorphites? spp. [m] and good matches of the classical species Kheraiceras bullatus (d'Orbigny) (Fig. 10).

\section{Bullatimorphites? spp. [m]}

(Fig. 10a, b)

The present record includes two small specimens, which are both microconchs with modified apertures, bearing short ventral rostra of the adult peristomes. The bigger form (Fig. 10a) is moderately involute, with inner whorls sphaerocone and last whorl developed as elliptic coiling. Due to preservation in marlstones, this example corresponds to an internal mould, which is highly compressed and deformed across the coiling axis, so that the real overlapping and whorl section cannot be observed. Earlier stages of growth were not seen. The last whorl is half septate and half of body-chamber. At the latter stage, the ornament corresponds to biplicate to triplicate ribs, which are separated by either simple or intercalated ribs. Ribs are broad, flat and concave; they are thin and branching near the midflanks on the phragmocone, and thick and branching in the peri-umbilical area on the body-chamber. In terms of its stratigraphic position, this ammonite comes from the lower Bathonian Siemiradzkia repljanensis Zone (Metodiev and Sapunov, 2017), which is a local equivalent of the Submediterranean Procerites (Siemiradzkia) aurigerus Zone (Mangold and Rioult, 1997).

The smaller form (Fig. 10b) is a flattened internal mould of medium state of preservation, with a narrow umbilicus in inner whorls that slightly expands on the last whorl. The ribbing is relatively strong, with dense and inclined forwards biplicate and triplicate ribs. Intercalated ribs seem also occurring, although randomly. Branching points of the ribs lie at mid-flank whorl height. The ornament of the body-chamber, which corresponds approximately to the inner half of the last whorl, consists of different ribs. The primary ribs are stronger and more distant and the secondary ribs gently curve backwards. The number of the secondary ribs seems to increase. There is a constriction behind the aperture, which is deep and prorsiradiate, developed slightly slantwise to the rib trajectory. This ammonite was found in the middle Bathonian Procerites prograci-

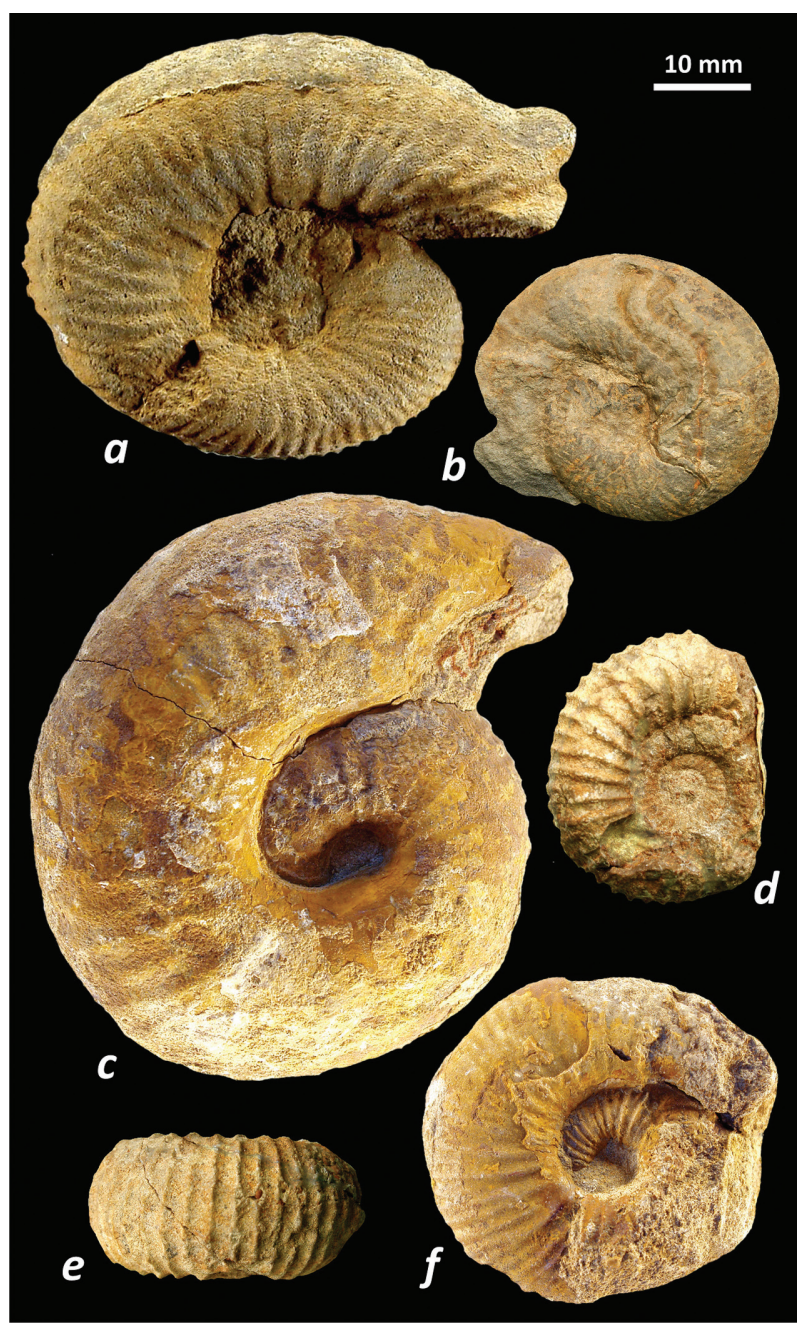

Fig. 10. Tulitidae and Parkinsoniidae from the Bathonian and the Callovian: a) Bullatimorphites? sp. [m], locality Bov (Bov Fm.), lower Bathonian, Siemiradzkia repljanensis Zone (Natural History Museum, Sofia); b) Bullatimorphites? sp. [m], locality Bov (Bov Fm.), middle Bathonian, Procerites progracilis Zone (Coll. GI-BAS, Inv.-Nr F.015831); c) Kheraiceras bullatus (d’Orbigny) [M], locality Granitovo (Yavorets Fm.), lower Callovian, Macrocephalites herveyi Zone (Coll. GIBAS, Inv.-Nr F.015833); d, e) Hemigarantia julii (d’Orbigny), locality Granitovo (Polaten Fm.), upper Bathonian, Procerites hodsoni - Oxycerites oppeli Zone (Coll. GI-BAS, Inv.-Nr F.015542); f) Kheraiceras bullatus (d’Orbigny) [m], locality Granitovo (Yavorets Fm.), lower Callovian, Macrocephalites herveyi Zone (Coll. GI-BAS, Inv.-Nr F.015834). 
lis Zone, which is an approximate equivalent of the ammonite zone with the same name in the scheme of Mangold and Rioult (1997) for Submediterranean Europe (see Metodiev and Sapunov, 2017).

Equally, the state of preservation and some morphological aspects seen on the studied specimens do not allow their confident identification at both species and generic levels. According to their stratigraphic position, they might be of the Bullatimorphites latecentratus (Quenstedt)-Bullatimorphites sophanus (Boehm) group. However, Ammonites bullatus latecentratus (Quenstedt, 1887, pl. 77, fig. 6 - holotype; Hahn, 1971, pl. 6, fig. 3a, b-refigured holotype) clearly differs in several important respects, in particular, being bigger-sized and with different shape of the aperture, with broader and more curved ribs, and also having too low points of branching of the ribs at the end of the body-chamber. Bullatimorphites sophanus (Boehm, 1912, p. 150, pl. 35, figs. 2a, b) shows stronger, sharper and simpler ribbing, as well as longer body-chamber than those of here studied specimens.

\section{Kheraiceras bullatus (d'Orbigny) [M] and [m]}

(Fig. 10c, f)

This species is exemplified by two specimens, a macroconch (Fig. 10c) and microconch (Fig. 10f). The macroconch is complete adult with contracted body-chamber and contracted simple aperture, whereas the microconch is wholly septate with lacking aperture. Both specimens are of small size, with spindle- to barrel-shaped inner whorls. Up to diameter of $40 \mathrm{~mm}$, the umbilicus is occluded, with a swollen periumbilical area. On the first half of the last whorl, the umbilicus widens suddenly, owing to the abrupt contraction of the dorsal part of the bodychamber. At this stage, the coiling becomes evolute and depressed. The body-chamber terminates in falcate margin, where there is another whorl contraction. Visible whorls seem to be ribbed throughout. The ribs are rectiradiate, generally simple, but bifurcate ribs also occur and the furcation points lie below the middle of the flanks. The rib relief decreases with growth and the ribs become radial to slightly inclined forwards. The microconchiate ammonite (Fig. 10f) is almost identical to Ammonites microstoma (d'Orbigny, 1846, p. 413, pl. 142, figs. 3,4 ), which, after revision of the original collection of d'Orbigny, was recognized in two specimens and reinterpreted as "Bullatimorphites bullatus forme microconque microstoma" (Thierry et al., 1994, p. 132, pl. 56, figs $2 a-c, 3 a-b)$. In terms of their stratigraphical range, Bulgarian specimens indicate the lower Callovian Macrocephalites herveyi Zone, which is equivalent to both the Subboreal Herveyi Zone and the Submediterranean Bullatus Zone (see Thierry et al., 1997). The index "herveyi" is a new zonal name for the lower Callovian of Bulgaria, which is only noticed here, but will be defined in biostratigraphic sense elsewhere.

\section{PARKINSONIIDAE BUCKMAN, 1920}

The members of this family occur in low numbers in Bulgaria. Hitherto, parkinsoniids have been recorded in just a few localities, with scattered geographical distribution that yielded examples of the following genera: Strenoceras Hyatt, 1900; Pseudogarantiana Bentz, 1928; Garantiana Macke, 1907; Parkinsonia Bayle, 1978; Gonolkites Buckman, 1925; Durotrigensia Buckman, 1928; and Caumontisphinctes Buckman, 1920 (e.g., Tzankov and Bonchev, 1934; Jordanov and Spasov, 1955; Sapunov and Stephanov, 1964; Sapunov and Tchoumatchenco in: Cheshitev et al., 1995; Sapunov, pers. comm.). Most of these faunas occur in the upper Bajocian Strenoceras niortense, Garantiana garantiana and Parkinsonia parkinsoni ammonite zones, and only single representatives continue ranging in the lowermost Bathonian Gonolkites convergens Zone (see Metodiev and Sapunov, 2017).

The genus Hemigarantia Spath, 1928, which is also a typical member of this family, has not been known in Bulgaria so far. The present record corresponds to a single specimen of the type-species of this genus, namely Hemigarantia julii (d'Orbigny), which comes from a mixed assemblage that, from biostratigraphic viewpoint, is consistent with the combined extent of the Procerites hodsoni and Oxycerites oppeli zones of the upper Bathonian (Metodiev and Sapunov, 2017). This sudden appearance, even with a single record, is in full agreement with the record of Hemigarantia from the Western Tethyan areas (W European and NW African), where this genus is considered cryptogenic (see Schlögl et al., 2006, and references therein).

\section{Hemigarantia julii (d’Orbigny)}

(Fig. 10d, e)

The Bulgarian example of Hemigarantia julii (d'Orbigny) refers to a small-sized evolute ammonite, with depressed and coronate whorl section. The ornament is sharp and consists of both simple and bifid straight ribs, which are slightly weakened on venter by a narrow longitudinal band. Small tubercles are regularly developed at the points of bifurcation of the ribs and also at the ventro-lateral 
edge and on the venter. The simple ribs are invariably tuberculate in the same pattern as branched ribs. The studied Bulgarian specimen is almost identical to the holotype (Ammonites Julii d'Orbigny, 1846, p. 420, figs 6, 7), which was revised, discussed and figured by Elmi and Gauthier (1994, p. 135, pl. 53, figs $5 \mathrm{a}-\mathrm{c}$ ). The two specimens are similar, differing only in details of rib density and the Bulgarian ammonite being slightly more evolute and depressed than the French original. Hemigarantia julii (d'Orbigny) is a local index-species for the Central West and SE France of the lower subzone of the upper Bathonian Prohecticoceras retrocostatum Zone in the Submediterranean zonal scheme of Mangold and Rioult (1997). In Bulgaria, its span probably corresponds to the boundary interval between the Procerites hodsoni and Oxycerites oppeli zones, which is still not well defined, but seems to be coeval with the level of the stratigraphic occurrence of H. julii (see Metodiev and Sapunov, 2017).

\section{PERISPHINCTIDAE STEINMANN, 1890}

\section{Bajocian and Bathonian perisphinctids}

The earliest discernible record of Perisphinctidae in Bulgaria is that of Lobosphinctes Buckman, 1923 and Planisphinctes Buckman, 1922, which appear in abundance near the base and have a narrow range in the lowermost Bathonian. The former genus seems, however, to have emerged earlier, in the latest Bajocian, where it has been encountered as single specimens, along with rare ammonites of other perisphinctid genera, such as Leptosphinctes, Buckman, 1920, Bigotites Nicolesco, 1918 and Vermisphinctes Buckman, 1920. These faunas usually do not compose distinct assemblages, and most of what is known so far is identifiable at generic level only. This level of scarcity is probably due to either unfavourable conditions of preservation or some unknown restrictions in ammonite dispersal. For the time being, that seems unalterable. Thus, the present record is a little contribution in this respect, with a single well-preserved early perisphinctid from the upper Bajocian Parkinsonia parkinsoni Zone - Lobosphinctes costulatosus (Buckman) (Fig. 11a, b).

After a few levels of abundance of Lobosphinctes (and Planisphinctes) in the lowermost Bathonian, Perisphinctidae continue ranging across the Bathonian of Bulgaria, but these ammonites retreat in occurrence or evolved into those of the genera $\mathrm{Ho}$ moeoplanulites and Siemiradzkia. The latter genus is particularly abundant and was carefully monographed by Stephanov (1972). Subsequently, little new data have been added (Metodiev and Sapu- nov, 2017). Hence, the discovery of an unspecified form that may represent a new species is somewhat surprising. This form has been found to be closely similar and matching in stratigraphic position with an example from the upper Bathonian of the French Jura Mts, which was studied by Mangold (1970). The latter author assumed that his specimen might be an unknown species but, because of the lack of enough material, he left it unnamed. The present study pays tribute to Mangold's discovery and the new species (Fig. 11c, d) is named after him. To support the new specific distinction, taxonomic notes given below also include comparisons with and illustration of a morphologically similar form that has recently been recognized in older Bulgarian collections. The latter form (Fig. 11e) came from the upper Bathonian strata of locality Prevala (NW Bulgaria). It is a good match of another recently defined Bathonian species, Homoeoplanulites mouterdei (Mangold et al., 2012). Both this form and its locality will be the subject of a separate study.

\section{Lobosphinctes costulatosus (Buckman)}

(Fig. 11a, b)

This species was identified on a small planulate, which is probably wholly septate, with no signs of adult features. The conch is regularly coiled, reaching to six whorls at most. The whorl section is high and oval, with shallow and undercut umbilical walls, slightly convex flanks and rounded venter. The ornament persists throughout, from the earliest growth stages up to the end of the last preserved whorl. In the inner whorls, up to diameter of $30 \mathrm{~mm}$, the sculpture is composed of very fine and dense prorsiradiate ribs. On the last whorl, the ribbing becomes sharp and it seems that there is a regular alternation of single and bifurcate ribs. Shallow and indistinct irregular constrictions also seem to be present. This specimen is coeval in occurrence with and morphologically identical to the inner whorls of the holotype (Buckman, 1923, pl. 386). It is especially similar to the specimen figured by Olivero et al. (2010, pl. 1, fig. 3) from the GSSP for the Bathonian Stage in Bas Auran (Geopark of HauteProvence, France).

\section{Siemiradzkia mangoldi sp. $\mathrm{n}$. [m]}

(Fig. 11c, d)

1970 Procerites (m. Siemiradzkia) nov. sp. B. Mangold, p. 47, figs 23, 24; Pl. 5, fig. 1.

Derivatio nominis. The species is named after $\mathrm{Dr}$ Charles André Mangold (1933-2014), a world-re- 


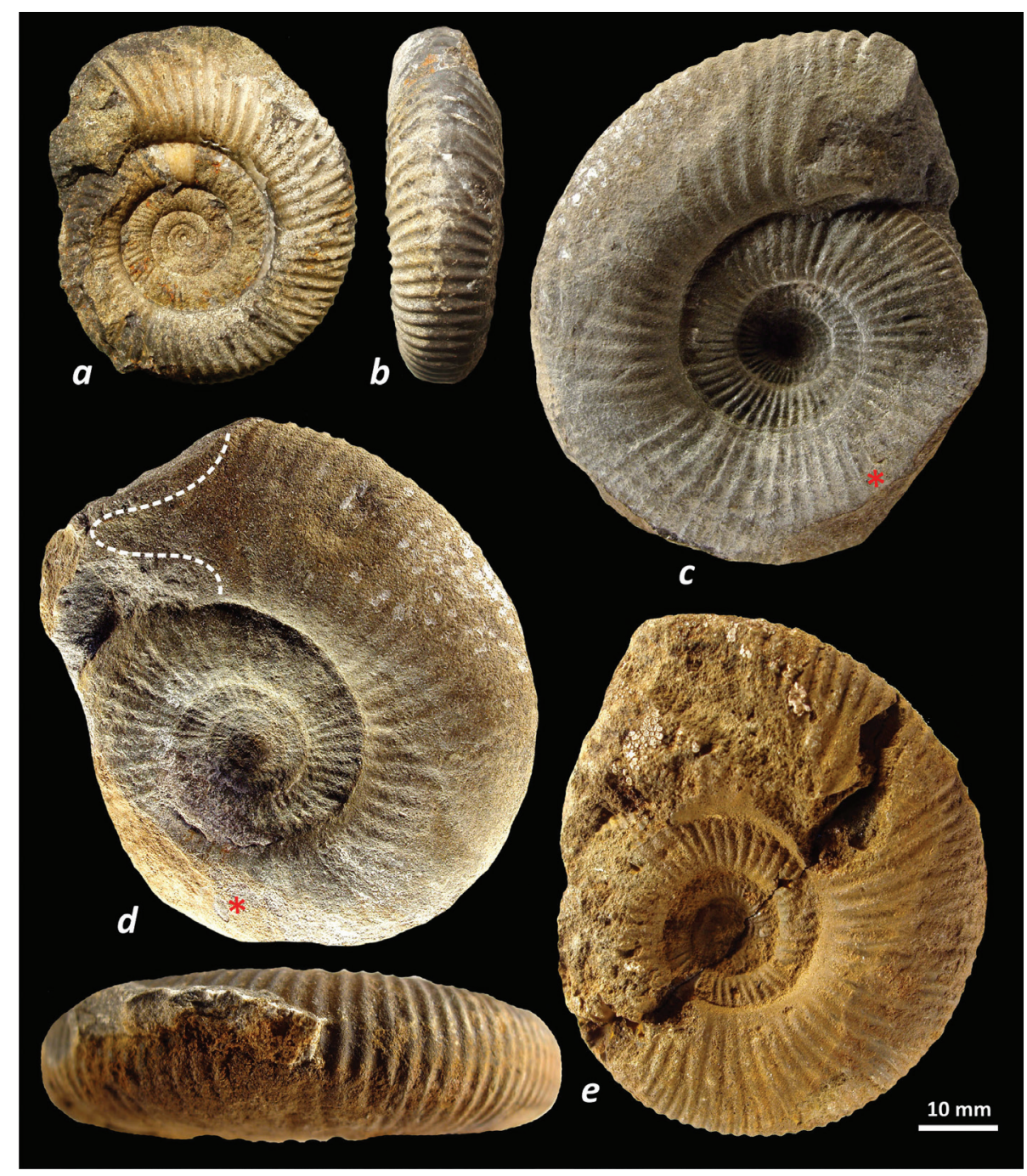

Fig. 11. Bajocian and Bathonian Perisphinctidae: $a, b)$ Lobosphinctes costulatosus (Buckman), locality Dolni Lom (Polaten Fm.), upper Bajocian, Parkinsonia parkinsoni Zone (Coll. GI-BAS, Inv.-Nr F.015830); c, d) Siemiradzkia mangoldi sp. n. [m], locality to the north of Komshtitsa Village (Bov Fm.), upper Bathonian, Oxycerites oppeli Zone (Coll. GI-BAS, Inv.-Nr F.015589); e) Homoeoplanulites mouterdei Mangold, Martin \& Prieur [m], locality Prevala (Polaten Fm.), upper Bathonian, Procerites hodsoni Zone (Coll. GI-BAS, Inv.-Nr F.015822).

nowned and highly respected French palaeontologist and stratigrapher, who devoted more than 40 years to the study of the Middle Jurassic ammonites.

Type. Holotype (repository number F.S.L. 18 620, Département des Sciences de la Terre, Faculté des Sciences de Lyon, collection C. Mangold), from "Calcaires roux et spathiques", upper Bathonian, Retrocostatum Zone, at "ferme de Malafroux", Vénérieu (Isère, France) (Mangold, 1970, p. 47, figs 23, 24; pl. 5, fig. 1).

Material from Bulgaria. Two specimens (repository numbers F.015589 and F.015820, Geological Institute, Bulgarian Academy of Sciences), from the upper Bathonian (Bov Formation, uppermost part),
Oxycerites oppeli Zone, near Komshtitsa and Gintsi villages (Western Balkan Mts, Bulgaria).

Diagnosis. Siemiradzkia with long ribs and very short parabolic stage developed at the beginning of the body-chamber, and moderate rib-density, which tends to decrease with growth; at $50-70 \mathrm{~mm}$ diameter, there are 24-26 ribs per half whorl and, at 70-93 mm diameter, 21-22 ribs per half whorl. The peristome conforms to a short lappet, with ventral cap and short apophysis, whose distal end is curved ventrally.

Description. Medium-sized, compressed and evolute ammonites. Whorl section is rounded subrectangular, with $\mathrm{Wh} / \mathrm{D}$ and $\mathrm{Wb} / \mathrm{D}$ ratios varying 
between 0.32 and 0.35 , and 0.22 and 0.27 , respectively. The umbilicus is shallow, bordered by low and steep umbilical walls and a poorly defined umbilical edge. The U/D ratios vary from 0.39 to 0.43 and tend to increase with growth. The venter is moderately broad and low-rounded, sub-tabulate at the beginning of the body-chamber and narrowing towards the aperture. The phragmocone ends at diameter of $50 \mathrm{~mm}$ to $65 \mathrm{~mm}$. Maximum known size is $93 \mathrm{~mm}$ diameter. The body-chamber extends approximately on the last two-thirds of the final whorl and ends with flap-like lappet. The ribbing persists throughout. Inner and intermediate whorls are ornamented by fine, dense, prorsiradiate simple and biplicate ribs. At the beginning of the body-chamber, there are four pairs of parabolic ribs that end up high on the flanks, with slightly expressed parabolic nodes. After this short stage of irregular ribbing, the ornament continues ordinarily but becomes flexuous. Seventeen prorsiradiate primary ribs are developed up to the peristome. Ribs curve backwards over most of the side of the whorl and divide into two long secondaries. Each rib pair goes along with one or two intercalatory ribs. The last few ribs before the aperture are thickened. The mouth-border is immediately preceded by a slight constriction.

Dimensions (see Table 2).

Discussion. In describing this new form, Mangold (1970, p. 47) compared his specimen with a cast of the holotype for Siemiradzkia tuberculata (Stephanov in: M.S.) solely. The latter ammonite is probably part of a material that July Stephanov intended to include in his monograph on the genus Siemiradzkia, but, due to his untimely death, he failed to do that. It is known that this monograph was published posthumously and, perhaps, some of Stephanov's taxonomic views have not found a place in his original manuscript, which remained unfinished. Recent efforts to find some labelled specimens amongst the ammonites from the collection of Stephanov were not successful. Therefore, no commentary has been made here.

Siemiradzkia is a well-known genus for a possibly phylogenetically connected group of species, which started in the lower Bathonian and continued, with significant numbers, approximately to the top of the middle Bathonian. The present record, as well as the data from SE France of Mangold (1970) and Mangold et al. (2012), demonstrate that Siemiradzkia continues persisting in decreasing numbers into the upper Bathonian as well. The careful revision of the collection of Lissajous (1923), supported by abundant fresh material from the middle-upper Bathonian strata of Mâconnais and combined with the review of the monograph of Stephanov (1972), have led Mangold et al. (2012) to propose a sequence of the following five species:

5. Siemiradzkia nodosa sp. n. (including S. davitashvilii Stephanov, 1972 as a synonym). Upper Bathonian (Retrocostatum Zone).

4. Siemiradzkia escollensis sp. n. Middle Bathonian (Morrisi Zone-Fortecostatum Subzone).

3. Siemiradzkia richei sp. n. Middle Bathonian (Fortecostatum Subzone).

2. Siemiradzkia matisconensis (Lissajous) (including S. triballa and S. galla taken from Stephanov (1972) as morphological variants). Middle Bathonian (Bullatimorphus Subzone-Fortecostatum Subzone).

1. Siemiradzkia pseudorjazanensis (Lissajous) (including $S$. berthae (Lissajous) as a junior subjective synonym). Middle Bathonian (Bullatimorphus Subzone-Fortecostatum Subzone).

Table 2

Measurements (in $\mathrm{mm}$ ) and ratios of type specimens for Siemiradzkia mangoldi sp. $n$. ( $D_{\max }-$ maximum diameter; $D_{P h}-$ diameter of the phragmocone; $\mathrm{Bl}$ - body-chamber length; Wh - whorl height; Wb - whorl breadth; $U$ - umbilical width; NR $/ 2$ - number of the primary ribs per half whorl; $N R_{i i} / 2$ - number of the secondary ribs per half whorl)

\begin{tabular}{|c|c|c|c|c|c|c|c|c|c|c|c|c|}
\hline Specimens & $\mathbf{D}_{\max }$ & $\mathbf{D}_{\mathbf{P h}}$ & Bl & Wh & Wh/D & $\mathbf{W b}$ & $\mathbf{W b} / \mathbf{D}$ & $\mathbf{W b} / \mathrm{Wh}$ & $\mathrm{U}$ & $\mathrm{U} / \mathrm{D}$ & $\mathrm{NR}_{\mathrm{i}} / 2$ & $\mathrm{NR}_{\mathrm{ii}} / 2$ \\
\hline $\begin{array}{l}\text { Holotype } \\
\text { (F.S.L. } 18 \text { 620) }\end{array}$ & $\begin{array}{l}93.0 \\
\text { at } 78 \\
\text { at } 66\end{array}$ & 65.0 & $210^{\circ}$ & $\begin{array}{l}30.0 \\
26.0 \\
22.0\end{array}$ & $\begin{array}{l}0.32 \\
0.33 \\
0.33\end{array}$ & $\begin{array}{l}21.0 \\
19.0 \\
18.0\end{array}$ & $\begin{array}{l}0.22 \\
0.24 \\
0.27\end{array}$ & $\begin{array}{l}0.70 \\
0.73 \\
0.82\end{array}$ & $\begin{array}{l}40.0 \\
33.5 \\
26.5\end{array}$ & $\begin{array}{l}0.43 \\
0.43 \\
0.40\end{array}$ & $\begin{array}{l}21 \\
25 \\
24\end{array}$ & $\begin{array}{l}65 \\
- \\
-\end{array}$ \\
\hline \multicolumn{13}{|c|}{ Bulgarian specimens } \\
\hline F.015589 & $\begin{array}{l}70.0 \\
\text { at } 51\end{array}$ & 51.0 & $200^{\circ}$ & $\begin{array}{l}23.0 \\
19.0\end{array}$ & $\begin{array}{l}0.33 \\
0.35\end{array}$ & $\begin{array}{l}14.0 \\
12.0\end{array}$ & $\begin{array}{l}0.20 \\
0.23\end{array}$ & $\begin{array}{l}0.61 \\
0.63\end{array}$ & $\begin{array}{l}31.0 \\
20.0\end{array}$ & $\begin{array}{l}0.44 \\
0.39\end{array}$ & $\begin{array}{l}22 \\
26\end{array}$ & $\begin{array}{c}58 \\
-\end{array}$ \\
\hline F.015820 & $\begin{array}{l}65.0 \\
\text { at } 49\end{array}$ & 50.0 & $200^{\circ}$ & $\begin{array}{l}19.8 \\
15.6\end{array}$ & $\begin{array}{l}0.33 \\
0.32\end{array}$ & $\begin{array}{l}- \\
-\end{array}$ & $\begin{array}{l}- \\
-\end{array}$ & $\begin{array}{l}- \\
-\end{array}$ & $\begin{array}{c}27.0 \\
20 .\end{array}$ & $\begin{array}{l}0.42 \\
0.41\end{array}$ & $\begin{array}{l}24 \\
26\end{array}$ & $\begin{array}{c}56 \\
-\end{array}$ \\
\hline
\end{tabular}


This sequence can hardly be followed in Bulgaria due to frequent condensation phenomena. Nevertheless, Metodiev and Sapunov (2017) recently proposed a middle-upper Bathonian succession of Siemiradzkia species, which, by now including $S$. mangoldi sp. $\mathrm{n}$., is the following:

5. Siemiradzkia mangoldi sp. n. Upper Bathonian (Oxycerites oppeli Zone).

4. Siemiradzkia berthae (Lissajous). Upper Bathonian (Procerites hodsoni Zone).

3. Siemiradzkia matisconensis (Lissajous) (including S. triballa and S. galla of Stephanov (1972) as morphological variants). Middle Bathonian (Morrisiceras morrisi Zone).

2. Siemiradzkia pseudorjazanensis (Lissajous). Middle Bathonian (M. morrisi Zone).

1. Siemiradzkia davitashvilii (Stephanov). Middle Bathonian (Tulites subcontractus Zone).

Of these species, S. triballa and S. galla indeed appear to be morphological variants of Siemiradzkia matisconensis, being slightly different in whorl proportions and rib strength between each other (see Table 3). However, regarding S. nodosa and S. davitashvilii, as well as S. berthae and S. pseudorjazanensis, it is preferable to keep these species separate and not merge them into two even more variable species with longer range, because that would be both a retrograde step in their classification and against the evidence from Bulgaria.

Siemiradzkia berthae is the species morphologically closest to $S$. mangoldi sp. n. Comparisons with the whorl dimensions of these forms (Table 3) show that there are small distinctions between them and $S$. mangoldi differs in being slightly less evolute, with more compressed and less raised whorl section than $S$. berthae. Both species can reach a similar maximum diameter of about 70-90 mm, but $S$. berthae displays smaller diameter of the phragmocone with a longer body-chamber as compared with $S$. mangoldi sp. n. Both species are microconchiate forms, but $S$. berthae develops small and short spatulate lappets, whereas $S$. mangoldi has a longer and flap-like lappet. Siemiradzkia mangoldi sp. n. and S.berthae are very similar in having restricted development of the parabolic stage of the ornament, but $S$. mangoldi sp. n. differs in having less parabolic ribs, with less pronounced parabolic nodes. The ribbing in S. mangoldi sp. n. is more flexuous than that in $S$. berthae.

Compared to Siemiradzkia pseudorjazanensis, in S. mangoldi sp. n. both whorl height and umbilical width are smaller, and the largest difference is in the whorl height/breadth ratio, where $S$. mangoldi sp. n. is more compressed than S. pseudorjazanensis.

Table 3

Comparisons between some of the more important morphological characteristics of Siemiradzkia mangoldi sp. n. and several allied species of Siemiradzkia from the middle and the upper Bathonian (data taken from Stephanov, 1972, and Mangold et al., 2012; abbreviations are the same as in Table 2)

\begin{tabular}{|c|c|c|c|c|c|c|c|c|c|}
\hline Species & $\mathrm{D}_{\max }$ & $\mathrm{D}_{\mathrm{Ph}}$ & $\mathrm{Bl}$ & $\mathrm{Wh} / \mathrm{D}$ & $\mathrm{Wb} / \mathrm{D}$ & $\mathrm{Wb} / \mathrm{Wh}$ & $\mathrm{U} / \mathrm{D}$ & $\mathrm{NR}_{\mathrm{i}}$ & Parabolic stage \\
\hline $\begin{array}{l}\text { Siemiradzkia } \\
\text { mangoldi sp. n. }\end{array}$ & 70-93 & $50-65$ & $200-210^{\circ}$ & $0.32-0.35$ & $0.20-0.27$ & $0.61-0.82$ & $0.39-0.44$ & $42-52$ & $\begin{array}{l}4 \text { pairs of ribs, } \\
\text { weak nodes }\end{array}$ \\
\hline $\begin{array}{l}\text { S. berthae } \\
\text { (Lissajous) }\end{array}$ & $68-80$ & $45-50$ & $\sim 270^{\circ}$ & $0.32-0.38$ & $0.25-0.32$ & $0.71-1.89$ & $0.38-0.46$ & $\sim 50$ & $\begin{array}{l}5 \text { pairs of ribs, } \\
\text { weak nodes }\end{array}$ \\
\hline $\begin{array}{l}\text { S. pseudo- } \\
\text { rjazanensis } \\
\text { (Lissajous) }\end{array}$ & $\sim 60$ & $\sim 40$ & $240-270^{\circ}$ & $0.32-0.37$ & $0.30-0.39$ & $0.79-0.84$ & $0.44-0.46$ & $\sim 57$ & $\begin{array}{l}6 \text { pairs of ribs, } \\
\text { small nodes }\end{array}$ \\
\hline $\begin{array}{l}\text { S. matisconensis } \\
\text { (Lissajous) }\end{array}$ & 70-90 & $43-50$ & $\sim 270^{\circ}$ & $0.31-0.39$ & $0.25-0.34$ & $0.73-0.88$ & $0.37-0.43$ & $42-46$ & $\begin{array}{l}6 \text { pairs of ribs, } \\
\text { bold nodes }\end{array}$ \\
\hline $\begin{array}{l}\text { S. gala } \\
\text { Stephanov }\end{array}$ & 80-110 & $50-57$ & $\sim 270^{\circ}$ & $0.37-0.40$ & $0.28-0.31$ & $0.75-0.83$ & $0.35-0.39$ & $29-30$ & $\begin{array}{l}6 \text { pairs of ribs, } \\
\text { no nodes }\end{array}$ \\
\hline $\begin{array}{l}\text { S. triballa } \\
\text { Stephanov }\end{array}$ & $60-65$ & $40-55$ & $\sim 270^{\circ}$ & $0.38-0.41$ & $0.28-0.31$ & $0.69-0.81$ & $0.35-0.36$ & $40-60$ & $\begin{array}{l}6 \text { pairs of ribs, } \\
\text { no nodes }\end{array}$ \\
\hline $\begin{array}{l}\text { S. davitashvilii } \\
\text { Stephanov }\end{array}$ & $35-40$ & $22-28$ & $\sim 270^{\circ}$ & $0.35-0.37$ & $0.31-0.38$ & 0.89-1.09 & $0.40-0.41$ & $35-40$ & $\begin{array}{l}8-12 \text { pairs } \\
\text { of ribs, small } \\
\text { nodes }\end{array}$ \\
\hline $\begin{array}{l}\text { S. nodosa Mangold } \\
\text { et al. }\end{array}$ & $32-52$ & $18-27$ & $250-290^{\circ}$ & $0.30-0.39$ & $0.21-0.35$ & $0.75-1$ & $0.33-0.46$ & $24-34$ & $\begin{array}{l}6 \text { pairs of ribs, } \\
\text { small nodes }\end{array}$ \\
\hline
\end{tabular}


The differences in ornament between them are clear, since the parabolic stage of ribbing in S. pseudorjazanensis is longer and more pronounced than in $S$. mangoldi sp. n. In addition, the ornament in $S$. pseudorjazanensis is denser and less flexuous, with ribs branching higher on the flanks. As regards to Siemiradzkia matisconensis, it is very distinct from S. mangoldi sp. $\mathrm{n}$. by having stouter whorls, being less evolute and with coarser ornament that contains long and prominent parabolic stage. Regardless of whether $S$. nodosa and $S$. davitashvilii should be considered synonyms or not, these forms clearly differ from $S$. mangoldi sp. $\mathrm{n}$. because they never attain size greater than $52 \mathrm{~mm}$ in diameter.

Along with Siemiradzkia faunas from SE France, Mangold et al. (2012) studied in detail the abundant coexisting representatives of the genus Homoeoplanulites Buckman, 1922. The latter is a related genus that is probably derivative of Siemiradzkia, with origin that may have taken place at the beginning of the middle Bathonian, but the exact line of derivation is not clear. Both genera range parallelly in the middle and the upper Bathonian and are closely similar in morphology but seem to form distinct phylogenies. In Bulgaria, Homoeoplanulites appear in the Procerites hodsoni Zone (sensu Sapunov and Metodiev, 2017), have scattered occurrence throughout the upper Bathonian, and continue upwards into the lower Callovian. As stated by Metodiev (2015b), the foremost members of Homoeoplanulites contain mostly small evolute ammonites with conspicuous, irregularly ribbed (parabolic) inner whorls and weakly constricted outer whorls. In the context of this study, it is necessary to note that Siemiradzkia mangoldi sp. n. shares similarities with Homoeoplanulites mouterdei (Mangold et al., 2012, pp. 51-53, pl. 20, figs 1-9) based on their proportional dimensions, whorl section, and ornament. However, these ammonites occur in clearly lower stratigraphic levels [i.e., in the Bremeri Zone sensu Mangold and Rioult (1997) and Mangold et al. (2012), which, in Bulgaria, corresponds to the Procerites hodsoni Zone sensu Metodiev and Sapunov (2017)] than both the Bulgarian and the French specimens of $S$. mangoldi (see the occurrence below). Although these ammonites share an overall similar morphology, the direct comparison between available Bulgarian specimens shows that $S$. mangoldi (Fig. 11c, d) differs from $H$. mouterdei (Fig. 11e) in being more evolute, with more compressed and lower whorls, shorter bodychamber, and also by the lack of parabolic ribs and constrictions in the inner whorls.

Occurrence. Upper Bathonian. France, Retrocostatum Zone (Mangold, 1970); Bulgaria, Oxycerites oppeli Zone (sensu Metodiev and Sapunov, 2017).

\section{Callovian perisphinctids}

The highest record of Perisphinctidae that is taken into account in this study is confined to the Callovian of the Granitovo locality and of the sequence along the Nechinska Bara River (NW Bulgaria). The Granitovo locality yielded a remarkable pathological specimen that has previously been misidentified as Sigaloceras (Metodiev, 2015b), but now attributed to Homoeoplanulites ex gr. moorei (Oppel in: Neumayr). The perisphinctids of the sequence along the Nechinska Bara River are highly reminiscent of those described by Cox (1988) from the UK and, therefore, their identification, both at species and generic levels, has been carried out on definitions and extents justified in this work. However, these forms still remain a subject to further confirmation and they are more or less provisionally referred to the following species: Binatisphinctes aff. binatus (Leckenby), Binatisphinctes cf. hamulatus (Buckman) $[\mathrm{M}]$, Binatisphinctes ex gr. rjasanensis (Teisseyre), B. rossicus (Siemiradzki), Choffatia poculum (Leckenby), Choffatia sp. cf. Choffatia trina (Buckman) and Alligaticeras aff. rotifer (Brown).

\section{Homoeoplanulites ex gr. moorei (Oppel in: Neumayr)}

(Fig. 12a-c)

This form corresponds to a medium-sized, moderately evolute and compressed ammonite that corresponds to an internal mould of incomplete phragmocone, with partly preserved test. The umbilicus is deep, bordered by steep umbilical walls and rounded umbilical edge, and showing a slight variation in umbilical width/diameter ratios as measured on both sides, from 0.31 to 0.33 . The whorl section is higher than wide, with a maximum whorl breadth near the periumbilical area, and almost flat whorl sides, which converge towards a moderately wide and round venter. The specimen is ribbed throughout and shows entirely different ornament on the two sides. On one lateral side, the ribbing is relatively fine and fasciculate, and consisting of short and thick concave periumbilical primaries that divide into three or more long and convex secondary ribs (see Fig. 12a). A series of undulating depressions are developed at the point of branching of the ribs. The ribs are deformed but pass without interruption throughout the venter (Fig. 12b). On the opposite lateral side, the ribs are also relatively close together and branched, but they are straight to slightly prorsiradiate, either biplicate or triplicate and short intercalatory ribs often occur (Fig. 12c). The long primary ribs branch out imme- 


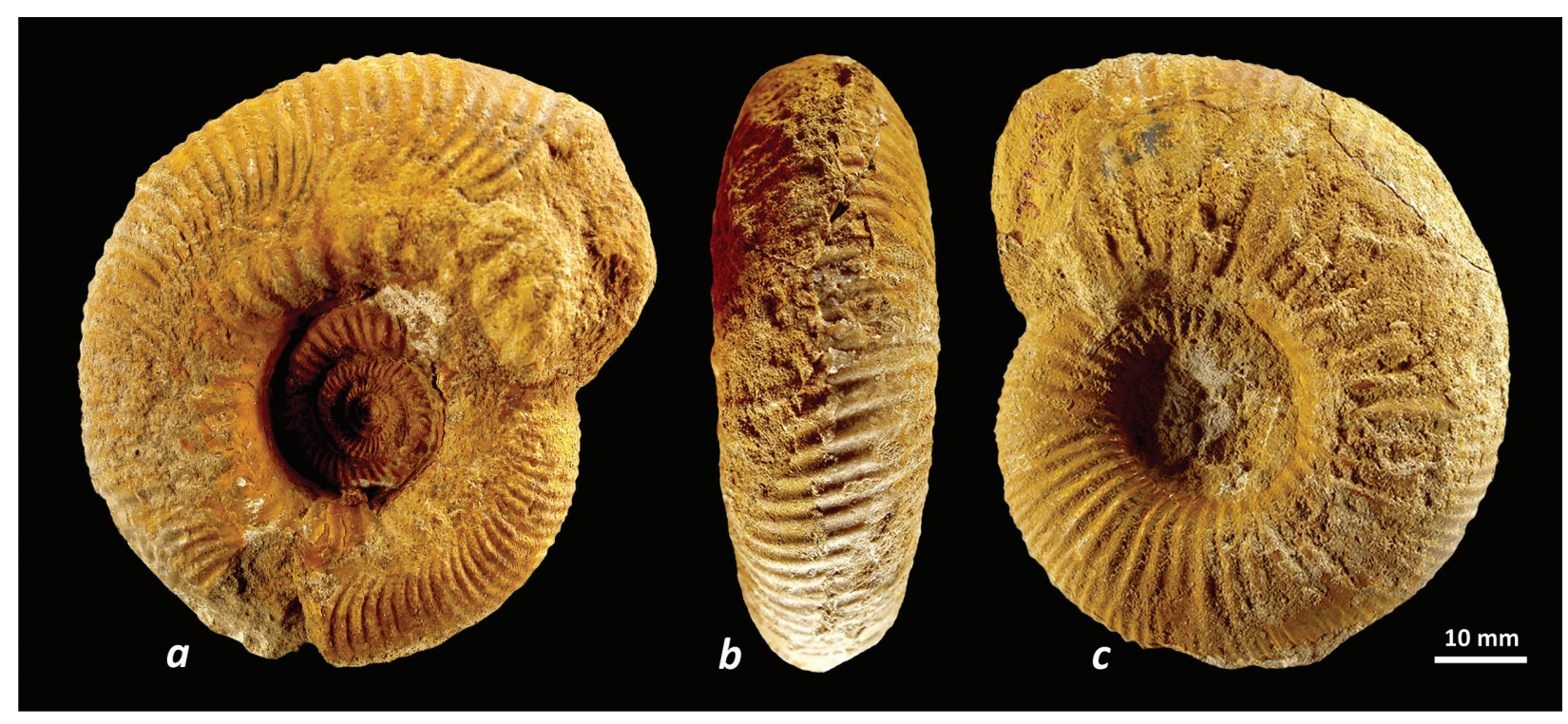

Fig. 12. Homoeoplanulites ex gr. moorei (Oppel in: Neumayr), pathological specimen showing entirely different ornament on the two sides, locality Granitovo (Yavorets Fm.), lower Callovian, Macrocephalites gracilis Zone (Coll. GI-BAS, Inv.-Nr F.015832).

diately above the mid-flanks. A few shallow constrictions are developed on this side of the whorl.

The observed "generically and specifically different" sides of the same specimen pose two questions: what is the true taxonomic affinity of this individual, and how can it be classified with the existing nomenclature of ammonite palaeopathology? As stated above, this ammonite comes from the locality Granitovo, where condensed ammonite faunas of late Bathonian-early Callovian age are present. The ammonite assemblages of both ages associate with rock packages separated by a sharp erosional surface that clearly divides the ammonites of different ages from each other. The accompanying ammonites of the studied specimen [e.g., K. bullatus, Macrocephalites ex gr. liberalis-lophopleurus (Buckman), as well as diverse Indosphinctes and Homoeoplanulites] suggest that the age is early Callovian. The assemblage seems to enclose almost the entire lower Callovian and, biostratigraphically, includes both the above-mentioned "Macrocephalites herveyi Zone" and the herein proposed name "Macrocephalites gracilis Zone". Both labels are well known from the European lower Callovian (see Mangold and Rioult, 1997), but in Bulgaria currently remain without appropriate characterization. Nevertheless, there is no doubt that they stand behind relevant faunal elements, on the basis of which their definition is forthcoming.

The style of ribbing on the lateral side, shown in Fig. 12a, was initally thought to be akin to the lower Callovian kosmoceratid genus Sigaloceras
Hyatt, 1900. However, the rib furcation points are too high, the rib ratio is too low, and there are no nodes at the points of branching of the ribs, so that the true sculpture ought to be on the opposite side of this specimen (see Fig. 12c). Consequently, this ornament is inherent to the genus Homoeoplanulites Buckman, 1922. Taking into account the style of ornament, as well as whorl dimensions and whorl shape, the specimen examined is interpreted as Homoeoplanulites ex gr. moorei (Oppel in: Neumayr). In general, Homoeoplanulites moorei seems still poorly determined species that is recognizable mainly on the basis of the type specimen described and figured by Neumayr (1868, p. 39, pl. 13, figs $1 \mathrm{a}-\mathrm{c})$. The original specimen of Neumayr differs from the Bulgarian example in being larger-sized. Therefore, the morphological similarities between these two ammonites are present up to the diameter of the specimen studied here. For this reason, the latter has only provisionally been referred to this species.

In terms of palaeopathology, Homoeoplanulites ex gr. moorei should be designated as "forma circumdata" sensu Hengsbach (1996), in which the ordinary ornament on one flank of the conch extends across the venter and, on the opposite flank, grades into sculpture characteristic of a different taxon. Apart from the venter, there are no other visible signs of distortion or deviation from the normal coiling in the studied specimen. No injuries or other abnormalities have been observed elsewhere on that ammonite, but the observed rib pattern was certain- 
ly caused by serious mantle damage. According to Hengsbach (1996), that abnormality might be attributed to ecological (metabolic-physiological) disorder or mutation. Although not very often, there are cases with Jurassic ammonites that are prone to such abnormal growth in the literature (e.g., Guex, 1967; Howarth, 1992). These abnormalities were found in horizons and localities associated with near-the-top of the ranges of some genera, i.e., above the levels of their greatest abundances, above which they rapidly decline and disappear. It can be assumed that the occurrence of the Bulgarian example matches the same case; however, given that the latter is a single specimen derived from a condensed deposit, this assumption is difficult to justify.

\section{Binatisphinctes aff. binatus (Leckenby)}

(Fig. 13a)

This species was attributed to four specimens, only one of which is illustrated (Fig. 13a). The available material consists of probable microconchs, corresponding to phragmocones with incomplete body-chambers. These ammonites are mediumsized, with diameter between $62 \mathrm{~mm}$ and $83 \mathrm{~mm}$, compressed and evolute (Wh/D - c. 0.41), and having high swollen whorls. The whorl sides converge evenly both towards well-rounded umbilical edges and a narrow venter, the latter not being bordered by distinct ventro-lateral shoulders. The maximum whorl breadth is at the mid-flanks. Body-chamber is of unknown length and the aperture is also unknown. Ribbing is observed from the innermost to the last preserved whorl. To at most $35 \mathrm{~mm}$ diameter, ribbing is sharp, straight and dense. With increase of the diameter, ribbing becomes more widely spaced. On the outermost whorls, ribbing consists of long and thickened, slightly concave primary ribs, which over the middle of the flanks split into three or four secondaries, sometimes attended by short intercalatories. At the points of branching, ribs are gently curved backwards. Ribbing weakens on the venter by a narrow, smooth longitudinal band. Weak and irregular development of parabolae and shallow constrictions are observed on outer whorls.

The presented Bulgarian material is morphologically similar to both the lectotype and the paralectotype designated and figured by Buckman (1921, pls 261A, B), and to the specimen figured by Cox (1988, pl. 21, fig. 5; see also pl. 21, figs 1a, b refiguration of Buckman's lectotype, as well as pl. 21 , figs 2a, b - refiguration of the paralectotype), which are from Yorkshire. However, the English specimens differ in being less evolute and having denser ornament, with a more pronounced disruption of the ribs on the ventral area. Microconchs of Binatisphinctes comptoni (Pratt), from southern and central England, as illustrated by Cox (1988, pl. 14, figs 6 , 7; pl. 15, figs 1-8), are also similar to the Bulgarian material, but differ in a number of important respects, in particular, in ornament, which seems less complicated than that in Bulgarian specimens, and also in having much narrower umbilicus, and often reaching larger sizes.

\section{Binatisphinctes cf. hamulatus (Buckman) [M] (Fig. 13b)}

It was assigned to a single poorly preserved specimen. It is an almost complete adult, with diameter slightly above $150 \mathrm{~mm}$ that corresponds to the phragmocone and the body-chamber of unknown length. It is planulate, with shallow and wide umbilicus, which is bordered by steep umbilical walls that become almost vertical at the end of the coiling. Whorl section is rounded and more compressed in inner whorls. Simple ribs were seen in separate sectors of the inner whorls. From the last half of the penultimate whorl to the first half of the last whorl, ribbing consists of thick and distant primaries that bifurcate near mid-flanks. Primary ribs are slightly prorsiradiate and developed from the umbilical seam. Secondary ribs are gently curved backwards. Intercalated ribs and weak irregular constrictions also occur. Ribbing seems to change on the last half of the final whorl, but it is poorly preserved, and only very thick and widely spaced ribs can be observed on the inner sides of the flanks.

The studied specimen cannot be compared to the holotype for Binatisphinctes hamulatus (Buckman), because the latter individual represents a microconch of a different morphology (see Buckman, 1921, pl. 262A; see also Cox, 1988, pl. 18, fig. 6 - refigured holotype). Bulgarian example is comparable with the adult macroconch from the Hackness Rock, near Scarborough (N Yorkshire), illustrated by Cox (1988, pl. 19).

\section{Binatisphinctes ex gr. rjasanensis (Teisseyre) (Fig. 13c, d)}

Teisseyre (1883, p. 586) proposed the new name Perisphinctes rjasanensis for five specimens from the Callovian of the Ryazan District (Russia), without designating a type. Four of them were figured (Teisseyre, 1883, pl. 6, figs. 40, 42, 43; pl. 7, fig. 41 ), and it seems that the type material consists entirely of small-sized and incomplete phragmocones that do not exceed $55 \mathrm{~mm}$ in diameter. Because of 


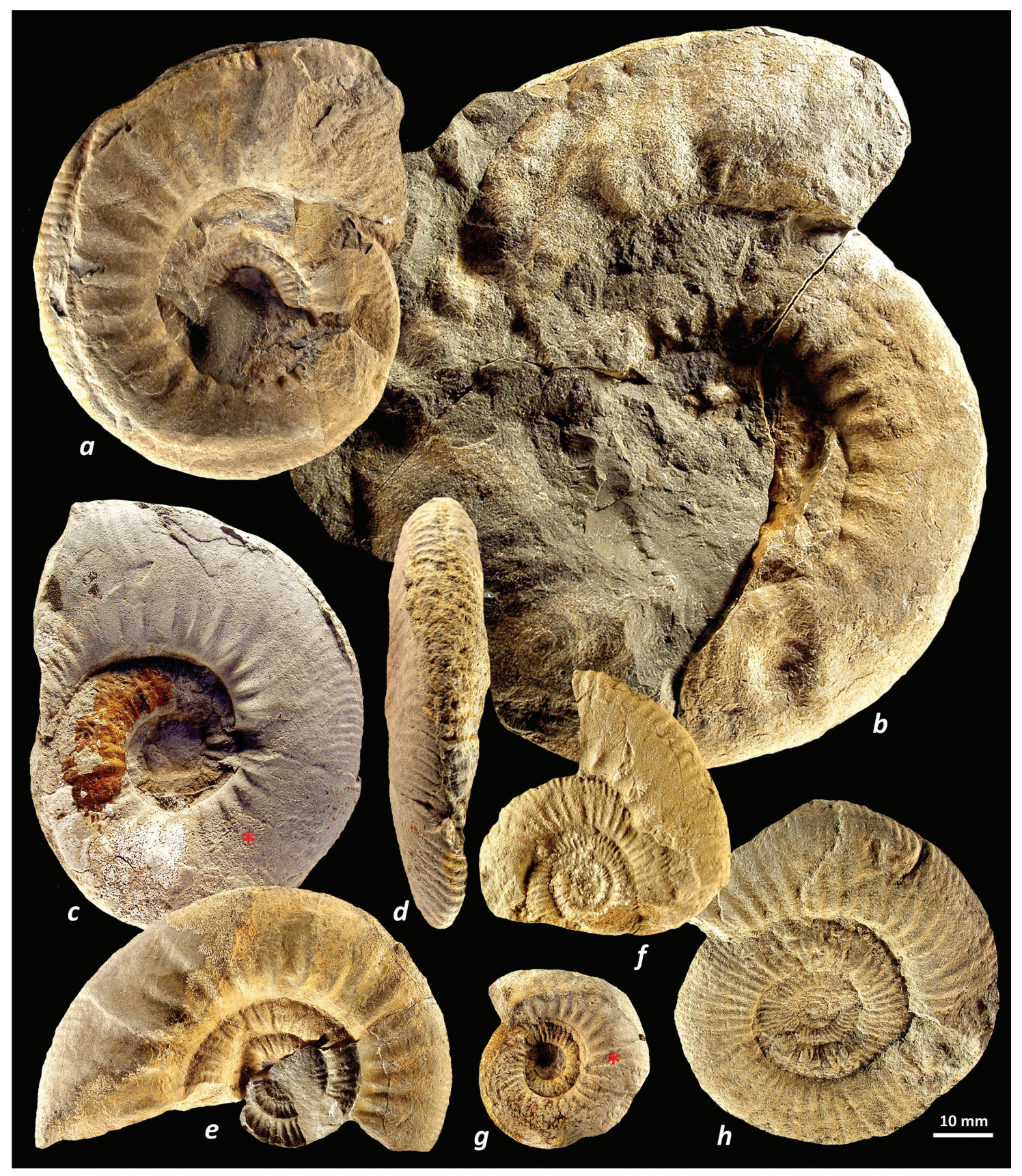

Fig. 13. Perisphinctidae from the Yavorets Formation of the section Nechinska Bara (upper Callovian, Pseudopeltoceras spp. Zone): a) Binatisphinctes aff. binatus (Leckenby) (Coll. GI-BAS, Inv.-Nr F.015836); b) Binatisphinctes cf. hamulatus (Buckman) [M] (Coll. GI-BAS, Inv.-Nr F.015837); c, d) Binatisphinctes ex gr. rjasanensis (Teisseyre) (Coll. GI-BAS, Inv.-Nr F.015844); e) Binatisphinctes ex gr. rossicus (Siemiradzki) (Coll. GI-BAS, Inv.-Nr F.015838); f) Choffatia poculum (Leckenby) (Coll. GI-BAS, Inv.-Nr F.015845); g) Choffatia sp. cf. Choffatia trina (Buckman) (Coll. GI-BAS, Inv.-Nr F.015840); h) Alligaticeras aff. rotifer (Brown) (Coll. GI-BAS, Inv.-Nr F.015847).

the incompleteness of these specimens, it is difficult to designate a lectotype. There is no evidence in the literature that this problem has been resolved. Hence, the species of Teisseyre, although defensible with a detailed original description, still remains open to varying interpretations.
The Bulgarian record that presumably belongs to $B$. rjasanensis (Teisseyre) corresponds to a single ammonite consisting of full phragmocone, with a diameter slightly less than $50 \mathrm{~mm}$, and incomplete body-chamber, reaching diameter of 74.5 mm, without preserved peristome (see Fig. 13c, $d$ ). 
Innermost whorls are not visible. The specimen is moderately evolute and compressed, with high elliptical whorls that slightly increase in height and decrease in breadth with growth. The umbilicus is shallow and decreases to a slight extent with respect to the diameter, from the earlier to the late ontogenetic stages. Umbilical walls are vertical to undercut, with rounded but distinct umbilical edge. Whorl sides are almost parallel and slightly convex. The venter is relatively broad and low rounded. The ornament is observable on the last two whorls, corresponding to the end of the phragmocone and the body-chamber. On the phragmocone, the ornament consists of fine and dense, simple and biplicate ribs that start from the umbilical seam. These ribs are composed of prorsiradiate and relatively long primaries, which at every several ribs are thickened. The secondary ribs gently bend backwards and go along with short and irregular intercalatories. At the end of the phragmocone and on the body-chamber, the ornament rapidly becomes more distant, flexuous and more complex. The primary ribs are shortened and become concave. The secondary ribs increase in number to three or four, incline forwards and slightly curve backwards in the ventro-lateral area. Ribbing smoothens on the venter due to the development of a thin and shallow groove. Weak constrictions and parabolae seem to be also present.

The absence of more specimens, on one hand, and the lack of preserved body-chambers of the type material for $B$. rjasanensis, on the other hand, do not allow the Bulgarian individual to be confidently accepted as evidence for the presence of this species. Besides, the original specimens of Teisseyre (1883) differ morphologically from the Bulgarian example. When estimating the similarity between the compared specimens, it should be noted that they have almost the same ornament on the phragmocones, but, in terms of the whorl proportions, the Bulgarian ammonite shows higher whorls and less evolute coiling.

\section{Binatisphinctes ex gr. rossicus (Siemiradzki)} (Fig. 13e)

Perisphinctes rossicus Siemiradzki (1899, p. 106) was proposed as a new name for Perisphinctes mosquensis (Fischer) sensu Lahusen (Lahusen, 1883 , p. 65, pl. 9, figs 4-6; Teisseyre, 1883, p. 592, pl. 7, figs 48, 50; pl. 8, fig. 47), as well as for a single small specimen of Siemiradzki's collection from the Callovian of the Ryazan District (Russia). As in the case of $B$. rjasanensis, there is a detailed description but no type designation. There is also no photograph, so only drawings of Lahusen
(1883) and Teisseyre (1883) are those which might suggest what the understanding of Siemiradzki for this species was. Thus, similarly to B. rjasanensis, Binatisphinctes rossicus was also originally based on incomplete phragmocones and careful revision of both species is extremely needed.

The Bulgarian material contributes little in this respect, because it is a single individual that both resembles and differs from the ammonites of the above listed old works. This is an evolute and compressed specimen that has no traces of septa or suture lines and, judging by its medium size, it is probably a wholly septate, with five whorls preserved. The umbilical walls are sloping and merge into a rounded umbilical edge. Whorl section converts from low and sub-quadrate at the inner whorls to high and elliptical at the last whorl, where the flanks are almost flat and converging towards a very low rounded venter. The ornament consists of dense and bundled ribs that are slightly inclined forwards on the dorsal half of the whorl, then bend gently backwards at the mid-lateral position, and then curve forwards on the ventral half of the whorl. The ribbing is grooved on the venter throughout. On the inner whorls, ribs are stronger and seem to include both parabolic elements and constrictions. On the last preserved whorl, ribbing corresponds to thick and widely spaced primaries that give rise to four thin secondaries. All rib bundles have thin intercalated ribs inserted in-between. There are several constrictions, combined with flared simple ribs that cut obliquely across the ordinary ribbing.

In terms of both the ornament and the whorl proportions of its inner whorls, the Bulgarian specimen is highly reminiscent of those figured by Teisseyre (1883) and Lahusen (1883) that were assigned by Siemiradzki (1899) to B. rossicus. The ornament on the last whorl of the Bulgarian example is, however, not observable in any of the specimens of the Ryazan area, and this led to its tentative identification.

\section{Choffatia poculum (Leckenby) (Fig. 13f)}

Leckenby's (1859, p. 9) original description of Ammonites poculum was too short, despite the fact that the author has demonstrated two morphologically divergent specimens. Cox (1988, p. 36) was probably the first to interpret figured specimens of Leckenby as a dimorphic pair - a smaller specimen with lappets (microconch) (Leckenby, 1859, pl. 1, fig. 4a) and inner whorls of a larger form (macroconch) (Leckenby, 1859, pl. 1, fig. 4b). Also, Cox (1988, pl. 12, figs 9, 11) was the first who became 
aware of and refigured Leckenby's original specimens together under a single specific name. Prior to that, Buckman $(1920$, pls 185, 186) separated these specimens into two different species, namely auricularis and poculum, and assigned them to a new genus, Poculisphinctes. Both names, although not very often, have appeared in the literature for a long time. Relying on well-collected areas with good stratigraphical control in Britain, Cox (1988) found, however, that assembling of macroconchs and microconchs of Choffatia poculum is not a difficulty. The problem to find a dimorphic pair, which has so often been discussed by others and has led to the referral to two different species, does not exist in this species. The present evidence is based on comparisons of a single Bulgarian specimen with the microconchiate forms recorded by Cox from the Lamberti Zone in North Yorkshire and Buckinghamshire (Cox, 1988, pp. 35-38, pl. 12, figs 11-14, 16).

The Bulgarian example of Choffatia poculum corresponds to an incomplete microconch with an approximate diameter of about $57 \mathrm{~mm}$. At least four whorls are visible and the last whorl contains the end of the phragmocone and the body-chamber $\left(\sim 230^{\circ}\right)$ without preserved aperture. It is moderately evolute and compressed, with slightly rounded whorl sides that converge towards a narrow and rounded venter. Umbilicus is wide and shallow, with sloping umbilical walls. Innermost whorls, up to diameter of $20 \mathrm{~mm}$, are ribbed with thin rectiradiate to prorsiradiate primary ribs, occasionally branching into two. With the increase of coiling, ribbing becomes stronger, more widely spaced and slightly inclined forwards, passing across the venter without interruption. The ribs branch above the mid-flanks into three secondaries, often with an intercalatory. Nodes, flares and weak constrictions also occur, although irregularly. On the last half of the bodychamber, ribs are further widely spaced, thickened at the base, and gently bent backwards in the innermost part of the flanks. This specimen seems closely similar to the microconchs studied by Cox (1988) in Yorkshire and Buckinghamshire, differing only in details of ribbing and having slightly larger diameter and whorl height, and wider umbilicus than those of the British examples, which in turn appears to be variability within this species.

\section{Choffatia sp. cf. Choffatia trina (Buckman)}

(Fig. 13g)

This tentative definition refers to two specimens that are the highest record of Choffatia in Bulgaria: a nucleus form and a small phragmocone with partly preserved body-chamber (see Fig. 13g). Illus- trated specimen is moderately evolute. Whorl section is rounded in inner whorls and becomes higher and moderately compressed in the outer whorl, having maximum whorl width near the peri-umbilical area. The shallow umbilicus is bordered by sloping umbilical walls and rounded umbilical edge. Flanks are slightly concave, passing without distinct marginal shoulder into gently rounded venter. Earlier whorls are finely and densely ribbed. Up to diameter of $\sim 30 \mathrm{~mm}$, ribs are prorsiradiate and bifurcate, slightly bending backwards on the venter. In later stages, to the end of the phragmocone, ribs become trifurcate, branching near the mid-flanks, and associated with fine intercalatories. Primary ribs incline forwards. On the phragmocone, ribbing coarsens and becomes far apart, with primaries that begin to be widely spaced and secondaries that weaken. Several shallow constrictions that follow the course of ribbing were observed. There is no interruption of the ornament on the venter.

Choffatia trina is a relatively rare form recorded in the uppermost Callovian of Britain, Poitou, NW Aquitaine Basin and Normandy (France), and Kachh (India). In fact, apart from the holotype (Buckman, 1922, pl. 332) and several specimens from Bedfordshire and Buckinghamshire in the UK (Cox, 1988, pl. 14, figs 2-5), it seems that there are no other figured specimens in the literature. Thus, the species still remains poorly known and the possible morphological deviations from the known specimens can hardly be assessed as falling into the variability of this species or as characteristic attributes of other similar forms. With some approximation, the Bulgarian material is morphologically identical to the holotype, although the latter is a wholly septate, whereas the specimen shown herein has a body-chamber. The British collection of Cox (1988) consists of macroconchs, some of which are larger, others of similar sizes, and thus being not comparable or fairly comparable with the illustrated Bulgarian example.

\section{Alligaticeras aff. rotifer (Brown)}

(Fig. 13h)

This single Bulgarian example of Alligaticeras Buckman, 1923 conforms in morphology to the defining characteristics of the first formal diagnosis of the genus that was given by Cox (1988, p. 49). As also said by Cox (ibid.), there was no original description at the introduction of Alligaticeras by Buckman (1923) and, initially, the genus accommodated a single species - Alligaticeras alligatum (Leckenby). In addition, Cox (1988, p. 51) analysed in detail the history of nomenclature of the second 
known species of Alligaticeras, A. rotifer (Brown), that was also examined by Buckman but was assigned to Perisphinctes.

The present record does not correspond to Alligaticeras alligatum but is conditionally referred to Alligaticeras rotifer. It is an incomplete adult, preserved as flattened clay mould consisting of five whorls. The coiling is evolute, with a shallow umbilicus that is bordered by steeply sloping umbilical walls. Whorl shape and dimensions cannot be truly estimated because of the preservation. The ornament is visible over diameter of $5 \mathrm{~mm}$. In the innermost whorls, up to diameter of $17 \mathrm{~mm}$, the ornament consists of very fine and dense prorsiradiate ribs. In the middle whorls (up to $30 \mathrm{~mm}$ in diameter), the ribs slightly thicken and become more distant, but retain their trajectory. Bifurcate ribs appear. Several shallow constrictions are developed. In outer whorls, the ribs continue bifurcating but are attended by intercalatories, and then trifurcate ribs appear. Ribs branch high up on the flanks and pass the venter without interruption. Constrictions continue developing, usually two or three per whorl.

Typical specimens of A. rotifer (Brown), as shown by Cox (1988, pl. 22, figs 1a, b - refigured holotype; pl. 22, figs 3-6 - small incomplete specimens; pl. 22, figs 2, 8 - larger incomplete specimens), are also more evolute, with a lower whorl height and coarser ribbing than the Bulgarian example. In addition, the British individuals are deeply constricted. The only specimens that bear resemblance to the Bulgarian ammonite are two specimens conditionally determined as Alligaticeras aff. rotifer by Cox (1988, pl. 23, figs 1, 2). They are similarly weakly constricted, have the same ornament and higher whorls as the Bulgarian example, but are less evolute. Another possible way to interpret the Bulgarian example is to assume that it could belong to Properisphinctes Spath, 1931. Indeed, Sapunov (1976a, b) found Properisphinctes bernensis (de Loriol) higher in the Oxfordian of the section at Nechinska Bara, and suggested that Properisphinctes should also be found in the upper Callovian strata. Arkell (1957, p. L320) opined that "[Properisphinctes] is doubtfully distinct from Alligaticeras". There are enough morphological characteristics, such as degree of involution, whorl proportions and shape of the umbilical wall and venter, that do not serve to distinguish between Alligaticeras and Properisphinctes as genera. The most significant difference is the ornament, which in Alligaticeras is denser and finer than in Properisphinctes. Therefore, the assumption that the specimen in question may represent a transitional form between Alligaticeras and Properisphinctes is also reasonable.
To conclude the notes on the upper Callovian perisphinctids that were included in this study, it is necessary to regard these forms in their stratigraphical context. It is striking that the upper Callovian levels of the section Nechinska Bara were typified by the distinct presence of Kosmoceras (Howarth and Stephanov, 1965). Several other sites in the Balkan Mts have also yielded additional Kosmoceras specimens, and the lack of other valuable material has led Kosmoceras compressum to be, for a long time, in use as an informal name labelling the upper Callovian. The selection of a more appropriate index is paramount as Kosmoceras is not a suitable choice of index-fossil, because it is too rare in Bulgaria. Based on the record from the section Nechinska Bara, it is better to propose, at least for now, the local Pseudopeltoceras spp. Zone. This zone corresponds to the total extent of the upper Callovian in this sequence, between the first occurrence of the genus Pseudopeltoceras Spath and the lowest occurrence of the genus Peltomorphites Buckman. The above-described perisphinctids display ranges, in which Binatisphinctes occurs in the lower parts of the upper Callovian, whereas Choffatia occurs primarily in the upper parts of the substage, probably reaching the Callovian/Oxfordian boundary but not beyond. Alligaticeras has single occurrence in mid-substage levels. The remaining diagnostic elements of the upper Callovian are Hecticoceratinae and Peltoceratinae, which are almost confined to the lower and the middle parts of the substage. The conclusion to be drawn from the present incomplete evidence is that some diagnostic indications of both the Submediterranean and the Subboreal upper Callovian Peltoceras athleta and Quenstedtoceras (Lamberticeras) lamberti Zones (Thierry et al., 1997) have been found in the section Nechinska Bara.

\section{CONCLUDING REMARKS}

Although being most often represented by single specimens, the newly discovered and newly interpreted ammonites of this study have high stratigraphical value. They are equally helpful for better dating the sedimentary successions, from which they have been collected, and are signs for the presence of ammonite taxa that were poorly documented in Bulgaria in the past. In addition, these ammonites are evidence of a faunal exchange, and thus may have value for correlation with the Northwestern and Tethyan (in part Subboreal) areas of Europe. They refer to genera of great interest in the framework of the overall ammonite occurrence 
in Bulgaria as they seem to reflect times of a great worldwide diversification of these molluscs.

\section{Acknowledgements}

The author wishes to thank the official journal reviewers Dr Sixto Rafael Fernández López (Complutense University of Madrid, Spain), Dr Mikhail Rogov (Geological Institute of Russian Academy of Sciences, Moscow), Dr José Sandoval (University of Granada, Spain) and Dr Christian Meister (Natural History Museum in Geneva, Switzerland) for their highly constructive suggestions and comments during the review process. Dr Georgi Granchovski and Prof. Iskra Lakova (Geological Institute, Bulgarian Academy of Sciences) are thanked for improving the language construction of the manuscript.

\section{REFERENCES}

Arkell, W.J., Kummel, B., Wright, C.W. 1957. Mesozoic Ammonoidea. Family Strigoceratidae. In: Moore, R.C. (Ed.), Treatise on Invertebrate Paleontology. Part. L. Mollusca. Cephalopoda, Ammonoidea. Geological Society of America and University of Kansas Press, Kansas, pp. L271-L272, L320.

Bardin, J., Rouget, I., Cecca, F. 2013. Late Pliensbachian (Early Jurassic) ammonites from the Lac de Charmes (HauteMarne, France): Systematic, biostratigraphy and palaeobiogeography. Geodiversitas 35 (2), 309-334.

Bayle, E. 1878. Atlas des Fossiles principaux des terrains, Paris. Explications de la carte géologique de France 4, 1ère partie, 158 pls.

Benatov, S. 1994. The Lower Jurassic of the region of the Gintsi Cliff and Vradlovtsi Village. Master's thesis, Sofia University “St Kliment Ohridski”, 163 pp. (in Bulgarian, unpublished).

Benshili, K. 1989. Lias-Dogger du Moyen-Atlas plissé (Maroc). Sédimentologie, biostratigraphie et évolution paléogéographique. Documents des Laboratoires de géologie de Lyon 106, 285 pp.

Boehm, G. 1912. Beiträge zur Geologie von NiederländischIndien. Palaeontographica 4 (1), 121-179.

Braga, J.C. 1983. Ammonites del Domeriense de la Zona subbética (Cordilleras beticas, Sur de España). Thesis Doctoral, Universidad de Granada, 410 pp. (unpublished).

Buckman, S.S. 1893. A monograph of the Inferior Oolite Ammonites of the British Islands. Monograph of the Palaeontographical Society London 8 (47), 345-376.

Buckman, S.S. 1910. Certain Jurassic ('Inferior Oolite') species of ammonites and brachiopoda. The Quarterly Journal of the Geological Society of London 66, 90-108.

Buckman, S.S. 1913-1930. Yorkshire Type Ammonites 5, continued as Type Ammonites 3-7, pls. 68-790. Weldon and Wesley, Thame \& London.

Callomon, J.H., Chandler, R.B. 1990. A review of the ammonite horizons of the Aalenian-Lower Bajocian stages in the Middle Jurassic of southern England. Memorie Descrittive della Carta Geologica d'Italia 40, 86-111.

Callomon, J.H., Chandler, R.B. 1994. Some early Middle Jurassic ammonites of Tethyan affinities from the Aalenian of southern England. Palaeopelagos Special Publication 1, Proceedings of the $3^{\text {rd }}$ Pergola International Symposium, 17-40.

Chandler, R.B., Callomon, J.H., King, A., Jeffreys, K., Varah, M., Bentley, A. 2006. The stratigraphy of the Inferior Oolite at South Main Road Quarry, Dundry, Avon. Proceedings of the Geologists’ Association 117, 345-375.
Cheshitev, G., Milanova, V., Sapunov, I., Tchoumatchenco, P. 1995. Explanatory note for the geological map of the Republic of Bulgaria in scale 1:100 000, Teteven map sheet. Committee of Geology, Sofia, 94 pp. (in Bulgarian, with English summary).

Courville, P., Thierry, J., Cariou, E. 1999. Modalités évolutives du genre Bullatimorphites (Ammonitina) au Bathonien-Callovien (Jurassique moyen) en Europe occidentale. Comptes rendus de l'Académie des Sciences Paris, Paléontologie 328, 59-65.

Cox, B.M. 1988. English Callovian (Middle Jurassic) perisphinctid ammonites. Part 1. Monograph of the Palaeontological Society, London 375 (110), 1-54, pls. 1-23.

Dabovski, C., Boyanov, I., Khrischev, Kh., Nikolov, T., Sapunov, I., Yanev, Y., Zagorchev, I. 2002. Structure and Alpine evolution of Bulgaria. Geologica Balcanica 32 (3-4), 9-15.

Dietze, V., Chandler, R.B., Schweigert, G. 2003. Witchellia pseudoromanoides n. sp. (Ammonoidea, Sonniniidae) aus der Laeviuscula-Zone (Mittlerer Jura, Unter-Bajocium) der östlichen Schwäbischen Alb (Süddeutschland). Stuttgarter Beiträge zur Naturkunde, Serie B 337, 1-25.

Dietze, V., Callomon, J.H., Schweigert, G., Chandler, R.B. 2005. The ammonite fauna and biostratigraphy of the Lower Bajocian (Ovale and Laeviuscula zones) of E Swabia (S Germany). Stuttgarter Beiträge zur Naturkunde, Serie B 353, 1-82.

Dietze, V., Chandler, R.B., Callomon, J.H. 2007. The Ovale Zone (Lower Bajocian, Middle Jurassic) at Little Down Wood (Dundry Hill, Somerset, SW England). Stuttgarter Beiträge zur Naturkunde, Serie B 368, 2-45.

Dietze, V., Kutz, M., Franz, M., Bosch, K. 2009. Stratigraphy of the Kahlenberg near Ringsheim (Upper Rhine Valley, SW Germany) with emphasis on the Laeviuscula and Sauzei zones (Lower Bajocian, Middle Jurassic). Palaeodiversity 2, 19-65.

Dietze, V., Schweigert, G., Fidder, U., Wannenmacher, N. 2011. The Giganteuston Member of Öschingen (Humphriesianum Zone, Lower Bajocian, Swabian Alb), with comments on the genera Dorsetensia Buckman, 1892 and Nannina Buckman, 1927. Zitteliana A 51, 209-236.

Dietze, V., Rieber, H., Auer, W., Franz, M., Schweigert, G., Chandler, R.B., Rieter, M., Chiarini, R. 2014. Aalenian (Middle Jurassic) ammonites and stratigraphy of the Geisingen clay pit (SW Germany). Palaeodiversity 7, 61-127.

Donovan, D.T., Callomon, J.C., Howarth, M.K. 1981. Classification of the Jurassic Ammonitina. In: House, M.R., Senior, J.R. (Eds), The Ammonoidea. The evolution, classification, mode of life and geological usefulness of a major 
fossil group. Systematic Association, Academic Press London, New York, Toronto, Sydney, San Francisco, 101-155.

Dommergues, J.-L. 1987. L'évolution chez les Ammonitina du Lias moyen (Carixien, Domerien basal) en Europe occidentale. Documents des Laboratoires de Géologie de Faculté des Sciences de Lyon 98, 272 pp.

Dommergues, J.-L., Marchand, D., Sapunov, I., Thierry, J. 1987. Les faunes d'ammonites du Jurassique bulgare: une confirmation paléobiogéographique de l'isolement relatif de la région balkano-moesienne. Bulletin de la Société géologique de France 8 (3), 737-742.

Dommergues, J.-L., Meister, C., Mouterde, R. 1997. Pliensbachien. In: Cariou, E., Hantzpergue, P. (Eds), Groupe français d'étude du Jurassique. Biostratigraphie ouest-européen et méditerranéen: zonations parallèles et distribution des invertébrés et microfossiles. Bulletin du Centre de Recherche Elf Exploration Production, Mémoire 17, 15-23.

Dommergues, J.-L., Dugué, O., Gauthier, H., Meister, C., Neige, P., Raynaud, D., Savary, X., Trévisan, M. 2008. Les ammonites du Pliensbachien et du Toarcien basal dans la carrière de la Roche Blain (Fresnay-le-Puceux, Calvados, Basse-Normandie, France). Taxonomie, implications stratigraphiques et paléobiogéographiquees. Revue de Paléobiologie, Genève 27 (1), 265-329.

Douvillé, H. 1885. Sur quelques fossiles de la zone à Ammonites sowerbyi des environs de Toulon. Bulletin de la Société Géologique de France 13, 12-44.

Douvillé, H. 1890. Sur la classification des Cératites de la Craie. Bulletin de la Societé Geologique de France (Serie 3) $18 ; 275-292$.

Elmi, S. 1967. Le Lias Supérieur et le Jurassique Moyen de l'Ardèche. Documents des Laboratoires de Géologie de Lyon 19 (1), 846 pp., 206 texte-figs., 17 pls.

Elmi, S., Gauthier, H. 1994. Hemigarantia julii (d’Orbigny, 1846). In: Fischer, J.-C. (Ed.), Révision critique de la Paléontologie Française d'Alcide d'Orbigny incluant la réédition de l'original. Volume I. Céphalopodes Jurassiques. Muséum national d'histoire naturelle Paris, Masson, Paris, Milan, Barcelone, 135, pl. 53, figs 5a-c.

Elmi, S., Mouterde, R. 1997. Les faunes de Czernyeiceras (Hammatoceratinae, Ammonitina) à la limite du Toarcien et de l'Aalénien. Cahiers de l'Université Catholique à Lyon 10, 103-116.

Fauré, P. 2002. Le Lias des Pyrénées. Thèse de Doctorat, Université Paul-Sabatier - Toulouse III. Strata 2 (39), 761 pp., 356 figs, 25 pls.

Galácz, A. 1980. Bajocian and Bathonian ammonites of Gyenespuszta Bakony Mts, Hungary. Geologica Hungarica 39, 5-227.

Géczy, B. 1966. Ammonoïdes Jurassiques de Csernye, Montagne Bakony, Hongrie - Part I. (Hammatoceratidae). Geologica Hungarica 34, 1-276.

Géczy, B., Meister, C. 2007. Les ammonites du Sinémurien et du Pliensbachien inférieur de la montagne du Bakony (Hongrie). Revue de Paléobiologie, Genève 26 (1), 137-305.

Guex, J., 1967. Contribution a l'étude des blessures chez les ammonites. Bulletin des Laboratoires de géologie, minéralogie, géophysique et du Musée géologique de l'Université de Lausanne 165, 1-16.

Hahn, A.V. 1971. Die Tulitidae S. Buckman, Sphaeroceratidae S. Buckman und Clydoniceratidae S. Buckman (Ammonoidea) des Bathoniums (Brauner Jura Epsilon) im südwestdeutschen Jura. Jahreshefte des Geologischen Landesamts Baden-Württemberg 13, 55-122.

Hengsbach, R. 1996. Ammonoid Pathology. In: Landman et al. (Eds), Ammonoid Paleobiology, Volume 13 of Topics in Geobiology. Plenum Press, New York, 581-605.
Henriques, M.H. 1995. Les faunes d’ammonites de l’Aalénien Portugais: composition et implications paléobiogéographiques. Géobios Mémoire Spécial 18, 229-235.

Howarth, M.K. 1958. A monograph of the ammonites of the Liassic family Amaltheidae in Britain. Part 1 (111), Part 2 (112). Monograph of the Palaeontological Society, London, 1-26; 27-53.

Howarth, M.K. 1992. The ammonite family Hildoceratidae in the Lower Jurassic of Britain. Part 2. Monograph of the Palaeontological Society, London 590 (146), 107-200.

Howarth, M.K. 2013. Treatise Online, Number 57. Part L, Revised, Volume 3B, Chapter 4: Psiloceratoidea, Eodoceratoidea, Hildoceratoidea. Kansas University Paleontological Institute, Lawrence, Kansas, USA, 139 pp. (http://paleo. ku.edu/treatise2/treatise.html).

Howarth, M.K., Stephanov, J. 1965. The genus Kosmoceras in Bulgaria. Travaux sur la géologie de Bulgarie, Série Paléontologie 7, 135-149.

Imlay, R. 1964. Middle Jurassic (Bajocian) ammonites from the Cook Inlet region, Alaska. United States Geological Survey Professional Paper 418-B, 1-61.

Imlay, R. 1984. Early and Middle Bajocian (Middle Jurassic) Ammonites from Southern Alaska. United States Geological Survey Professional Paper 564, 1-38.

Jordanov, M., Spasov, Ch. 1955. Beitrag zur Stratigraphie des Jura beim Dorfe Straža, Kreis Tărgovište. Bulletin of the Geological Institute 3, 115-138 (in Bulgarian, with Russian and German abstracts).

Kamenov, B. 1936. La géologie des environs d'Etropole. Review of the Bulgarian Geological Society 8 (2), 30-137 (in Bulgarian, with French abstract).

Kovács, Z. 2009. Toarcian-Aalenian Hammatoceratidae (Ammonitina) from the Gerecse Mts (NE Transdanubian Range, Hungary). Fragmenta Palaeontologica Hungarica 29, 1-72.

Lahusen, I. 1883. Die Fauna der jurassischen Bildungen des Rjasanschen Gouvernements. Mémoires du Comité géologique St.-Pétersbourg 1 (1), 1-94 (in Russian).

Leckenby, J. 1859. On the Kelloway Rock of the Yorkshire coast. Quarterly Journal of Geology, London 15, 4-15.

Lissajous, M. 1923. Étude sur la faune du Bathonien des environs du Mâcon. Travaux du Laboratoire de Géologie de la Faculté des Sciences de Lyon, Mémoire 3, 281 pp.

Mangold, C. 1970. Les Perisphinctidae (Ammonitina) du Jura Méridional au Bathonien et au Callovien. Documents des Laboratoires de Geologie de Faculté des Sciences de Lyon 41 (2), 246 pp.

Mangold, C., Rioult, M. 1997. Bathonien. In: Groupe français d'étude du Jurassique, Cariou, E., Hantzpergue, P. (Eds), Biostratigraphie ouest-européen et méditerranéen: zonations parallèles et distribution des invertébrés et microfossiles. Bulletin du Centre des recherches Elf Exploration Production 17, 55-62.

Mangold, C., Martin, A., Prieur, A. 2012. Les Périsphinctidés du Bathonien moyen et supérieur du Mâconnais (Saône-etLoire, France). Documents des Laboratoires de géologie de Lyon 169, 155 pp.

Meister, C. 1988. Ontogenèse et évolution des Amaltheidae (Ammonoidea). Eclogae Geologicae Helvetiae 81 (3), 763-841.

Meister, C., Blau, J. 2014. Pliensbachian ammonites from the Central Apennines, Italy (Acquasparta section) - a revision of Fischer's collection and new data. Neues Jahrbuch für Geologie und Paläontologie, Abhandlungen 273 (3), 253-275.

Meister, C., Böhm, F. 1993. Austroalpine Liassic Ammonites from the Adnet Formation (Northern Calcareous Alps). 
Jahrbuch der Geologischen Bundesanstalt 136 (1), 163 211.

Meister, C., Dommergues, J.-L., Dommergues, C., Lachkar, N., El Hariri, K. 2011. Les ammonites du Pliensbachien du jebel Bou Rharraf (Haut Atlas oriental, Maroc). Géobios 44, 1-60.

Meister, C., Friebe, G. 2003. Austroalpine Liassic ammonites from Voralberg (Austria, Northern Calcareous Alps). Beiträge zur Paläontologie 28, 9-99.

Metodiev, L. 2000. Étude de la limite Toarcien-Aalénien et stratigraphie de l'Aalénien dans quelques coupes du Mont Balkan occidental et central en Bulgarie. Strata 1 (10), 117-121.

Metodiev, L. 2008. The ammonite zones of the Toarcian in Bulgaria - new evidence, subzonation and correlation with the standard zones and subzones in North-western Europe. Comptes rendus de l'Académie bulgare des Sciences 61 (1), 87-132.

Metodiev, L. 2015a. New examples of the genus Wagnericeras from the Bathonian in Bulgaria. Bulgarian Geological Society, National Conference with International Participation “Geosciences 2015”, Abstracts, 113-114.

Metodiev, L. 2015b. The Callovian Pseudoperisphinctinae from North-west Bulgaria. William Smith Meeting in honor of J.H. Callomon, Abstract booklet for delegates, Sherborne Castle (England), 9-11.

Metodiev, L. 2016. Phylloceratina ammonites from the Callovian in Western Bulgaria. Bulgarian Geological Society, National Conference with International Participation "Geosciences 2016", Abstracts, 121-122.

Metodiev, L. 2017. Ammonites of the family Sphaeroceratidae from the Bajocian in Bulgaria. Bulgarian Geological Society, National Conference with International Participation "Geosciences 2017", Abstracts, 93-94.

Metodiev, L., Sapunov, I. 2001. Aalenian and Lowermost Bajocian ammonites (Hammatoceratinae and Otoitidae) from the Western and Central Balkan Mountains (Bulgaria). Geologica Balcanica 31 (3-4), 59-70.

Metodiev, L., Sapunov, I. 2006. Revision of some CallovianUpper Jurassic lithostratigraphic units in a part of Northwest Bulgaria. Comptes rendus de l'Académie bulgare des Sciences 59 (5), 539-542.

Metodiev, L., Sapunov. I. 2017. The ammonite zones of the Bathonian in Bulgaria. Geologica Balcanica 46 (2), 5763.

Metodiev, L., Koleva-Rekalova, E., Dochev, D., Sirakov, V. 2013. New data on the age of the Polaten Formation in Central Balkan Mountains. Bulgarian Geological Society, National Conference with international participation "Geosciences 2013", Abstracts, 73-74.

Metodiev, L., Koleva-Rekalova, E., Ivanova, D., Dochev, D., Velev, S., Dimitrov, I. 2014. Middle Jurassic fossil and depositional record from the area of the Zimevitsa Plateau (West Bulgaria). Bulgarian Geological Society, National Conference with International Participation "Geosciences 2014”, Abstracts, 65-66.

Metodiev, L., Tsvetkova, N. 2014. Lower Bajocian ammonites from the stratotype section of the Etropole Formation kept in the Historical Museum in Etropole (Bulgaria). Geologica Balcanica 43 (1-3), 27-49.

Morton, N. 1972. The Bajocian ammonite Dorsetensia in Skye, Scotland. Palaeontology 15 (3), 504-518.

Morton, N. 1975. Bajocian Sonnoniidae and other ammonites from western Scotland. Palaeontology 18 (1), 41-91.

Nachev, I., Sapunov, I., Stephanov, J. 1963. Stratigraphy and lithology of the Jurassic System between Gorno Ozirovo and Prevala villages (North-west Bulgaria). Travaux sur la géologie de Bulgarie, Série Stratigraphie et Tectonique 5, 99-146 (in Bulgarian, with Russian and English abstracts).

Neumayr, M. 1868. Die Cephalopodenfauna der Oolithe von Balin bei Krakau. Abhandlungen der Kaiserlich-Königlichen Geologischen Reichsanstalt 28, 1-36.

Olivero, D., Pavia, G., Fernández-López, S.R., Mangold, C., Guiomar, M. 2010. Le GSSP du Bathonien à Bas Auran (réserve naturelle géologique de Haute-Provence, France). Géologie de la France 1, 65-77.

Özdikmen, H. 2013. A replacement name, Alcidia Rollier, 1913, for preoccupied genus Paralcidia Spath, 1928 (Ammonoidea: Haploceratina: Oppeliidae). Munis Entomology and Zoology 8 (1), 239-242.

d’Orbigny, A. 1842-1852. Paléontologie Française. Description zoologique et géologique de tous les animaux mollusques et rayonnés fossiles de France, comprenant leur application a la reconnaissance des couches. Terrains oolitiques ou Jurassiques. I. Céphalopodes. Paris, pp. 1-642, pls. 1-234.

Pavia, G. 1983. Ammoniti e biostratigrafia del Baiociano inferiore di Digne (Francia SE, Dip. Alpes-Haute-Provence). Monografie del Museo Regionale di Scienze Naturali, Torino, II, 258 pp.

Petitclerc, P. 1915. Essai sur la faune du Callovien dans le département des Deux-Sèvres et plus spécialement de celle des environs de Niort. Libraire et imprimerie Louis Bon, Vesoul (Haute-Saône), 144 pp., 14 pls.

Petrov, P. 2005. Facial analysis of the Lower-Middle Jurassic sediments from a part of the Western Balkanides, with attempt for interpretation of the synrift stage of development of the Jurassic-Lower Cretaceous Basin. Master's Thesis, Sofia University “St Kliment Ohridski”, 43 pp. (in Bulgarian, unpublished).

Quenstedt, F.A. 1886-1887. Die Ammoniten des Schwabischen Jura. II. Band. Der Braune Jura. Schweizerbart, Stuttgart, 441-815.

Rioult, M., Contini, D., Elmi, S., Gabilly, J., Mouterde, R. 1997. Bajocien. In: Cariou, E., Hantzpergue, P. (Eds), Groupe français d'étude du Jurassique. Biostratigraphie ouest-européen et méditerranéen: zonations parallèles et distribution des invertébrés et microfossiles. Bulletin du Centre de Recherche Elf Exploration Production, Mémoire $17,41-53$

Rogov, M.A. 2004. Essay on the stratigraphy of the Middle-Upper Jurassic of Sudak segment of the Mountainous Crimea (appendix to the article: Mileev, S.V., Baraboshkin, E.Yu., Rozanov, S.B., Rogov, M.A. 2004. Position of paleovolcano Karadag in the structure of the Mountainous Crimea). In: Morozova, A.L., Gnubkin, V.F. (Eds), Karadag. History, geology, botany, zoology (Collection of scientific works, dedicated to the $90^{\text {th }}$ anniversary of the Karadag scientific station T.I. Vyazemsky and the $25^{\text {th }}$ anniversary of the Karadag natural reserve). Sonata, Simferopol, 84-93, figs $1,2$.

Roman, F., Boyer, P. 1923. Sur quelques ammonites de la zone à Ludwigia murchisonae du Lyonnais. Travaux du Laboratoire de Géologie de la Faculté des Sciences de Lyon, Mémoire 4, 47 pp., 9 pls.

Rulleau, L. 1993. L'évolution des Grammoceratinae (Hildocerataceae, Ammonitina) au Toarcien supérieur, dans la region Lyonnaise. Géobios, Mémoire Spécial 15, 331-339.

Rulleau, L. 2011. Les ammonites du Bajocien en France et dans le Monde. Inventaire des genres et des espèces. Rulleau, L. (Ed.). 300 pp., 78 pls. Section Géo-paléo du Comité d'Établissement des carrières Lafarge à Lozanne.

Rulleau, L., Elmi, S., Thévenard, B. 2001. Géologie et paléontologie des dépôts ferrugineux du Toarcian et de l’Aalénien 
aux environs de Lyon. Documents des Laboratoires de géologie de Lyon 154, 153 pp., 24 figs, 31 pls.

Sacharieva-Kowatcheva, K. 1956. Faunistische und stratigraphische Untersuchung des Doggers im Westlichen Balkan. Annuaire de l'Université de Sofia, Faculté de biologie, géologie et géographie 49 (2), 217-346 (in Bulgarian, with German summary).

Sandoval, J., Chandler, R.B. 2000. The Sonniniid ammonite Euhoploceras from the Middle Jurassic of South-west England and southern Spain. Palaeontology 43 (3), 495-532.

Sandoval, J., O’Dogherty, Guex, J. 2001. Evolutionary rates of Jurassic ammonites in relation to sea-level fluctuations. Palaios 16, 311-335.

Sandoval, J., Henriques, M.H., Chandler, R.B., Ureta, S. 2012. Latest Toarcian-earliest Bajocian (Jurassic) Grammoceratinae (Hildoceratidae, Ammonitina) of the western Tethys: Their palaeobiogeographic and phyllogenetic significance. Géobios 45, 109-119.

Sapunov, I.G. 1961. Stratigraphy of the Jurassic in the Etropole and Teteven areas (Central Balkan Range). Travaux sur la géologie de Bulgarie, Série Stratigraphie et Tectonique 3, 93-137 (in Bulgarian, with Russian and English abstracts).

Sapunov, I. 1963. The ammonites of the Bajocian genus Protoecotraustes Spath (Haploceratidae). Travaux sur la géologie de Bulgarie, Série Paléontologie 5, 149-165, pl. 1 (in Bulgarian, with Russian and English abstracts).

Sapunov, I. 1968. New data about the ammonite zonal succession of the Aalenian in Bulgaria. Comptes rendus de l'Académie bulgare des Sciences 21 (6), 537-539.

Sapunov, I.G. 1969a. On the age of the iron ores of the PonorGradets Jurassic Strip (Western Balkan Range). Comptes rendus de l'Académie bulgare des Sciences 22 (7), 807810.

Sapunov, I.G. 1969b. On certain recent stratigraphical problems of the Jurassic System in Bulgaria. Bulletin of the Geological Institute, Series Stratigraphy and Lithology 18, 5-20 (in Bulgarian, with Russian and English abstracts).

Sapunov, I. 1971. The Bajocian ammonite genus Bradfordia S. Buckman, 1910 (Oppeliidae) in Bulgaria. Bulletin of the Geological Institute, Series Palaeontology 20, 73-90, pls 1-3 (in Bulgarian, with Russian and English abstracts).

Sapunov, 1976a. Ammonite stratigraphy of the Upper Jurassic in Bulgaria. I. Rocks and ammonite successions. Geologica Balcanica 6 (3), 17-40.

Sapunov, 1976b. Ammonite stratigraphy of the Upper Jurassic in Bulgaria. II. Oxfordian: Substages, zones and subzones. Geologica Balcanica 6 (4), 19-36.

Sapunov, I., Metodiev, L. 2007a. Main features of the Jurassic in Bulgaria. Comptes rendus de l'Académie bulgare des Sciences 60 (2), 169-178.

Sapunov, I., Metodiev, L. 2007b. The Hettangian-Pliensbachian ammonite zones and subzones in Bulgaria - a retrospection and correlation with the standard zones and subzones in North-western Europe. Comptes rendus de l'Académie bulgare des Sciences 60 (9), 991-1000.

Sapunov, I., Stephanov, J. 1964. The stages, substages, ammonite zones and subzones of the Lower and Middle Jurassic in the Western and Central Balkan Range (Bulgaria). In: Maubeuge, P.L. (Ed.), Colloque du Jurassique, Luxembourg 1962, Volume Comptes Rendus et Mémoires, 705718.

Sapunov, I., Tchoumatchenco, P., Shopov, V. 1971. Concerning certain features of the palaeogeography of the Teteven Area in the Early Jurassic. Bulletin of the Geological Institute, Series Stratigraphy and Lithology 20, 33-62 (in Bulgarian, with Russian and English abstracts).
Sapunov, I.G., Tchoumatchenco, P.V., Shopov, V.L. 1976. Stratigraphie et paléoécologie du Jurassique inferieur dans une partie de Bulgarie occidentale. Annuaire de l'Université de Sofia, Faculté de géologie et géographie 67 (1), 101-149.

Sapunov, I., Tchoumatchenco, P., Shopov, V. 1996. The Lower Jurassic in the Troyan Region and the south-eastern part of the Teteven Region, Central Balkanids (brachiopod-, bivalve- and ammonite stratigraphy and palaeotectonics). Geologica Balcanica 26 (3), 3-19.

Schlögl, J., Elmi, S., Rakús, M., Mangold, C., Ouahhabi, M. 2006. Specialization and iterative evolution of some Western Tethyan Bathonian ammonites [Benatinites (B.) nov., B. (Lugariceras) nov. and Hemigarantia]. Géobios 39, 113-124.

Schweigert, G., Atrops, F., Benetti, A., Veronese, V., Zeiss, A. 1999. The ammonite genera Oxydiscites Dacqué 1934 and Sphaerodomites Rollier 1909 (Strigoceratidae, MiddleLate Jurassic). Profil 16, 57-71.

Schweigert, G., Dietze, V., Balle, T. 2000. Dimorphismus und Phylogenie der Ammonitengattung Csernyeiceras Géczy (Früher Mitteljura, Phlycticeratinae). Stuttgarter Beiträge zur Naturkunde, Serie B 294, 1-13.

Schweigert, G., Dietl., G, Dietze, V. 2003. Neue Nachweise Phlycticeras und Qeoptychius (Ammonitina: Strigoceratinae: Phlycticeratinae). Stuttgarter Beiträge zur Naturkunde, Serie B 335, 1-21.

Siemiradzki, J. 1898-1899. Monographische Beschreibung der Ammonitengattung Perisphinctes. Palaeontographica 45, 69-352.

Sowerby, J. de C. 1823-25. The Mineral Conchology of Great Britain 5. Taylor Edition, London, pls 444-485 (1824).

Spath, L.F. 1938. Revision of the Jurassic cephalopod fauna of Kachh. Part II. Palaeontologia Indica, New Series, Volume 9, Memoire No. 2, 73-161, pls 8-19.

Stephanov, J. 1960. Representatives of the family Amaltheidae in Bulgaria. Travaux sur la géologie de Bulgarie, Série Paléontologie 2, 265-294 (in Bulgarian, with Russian and English abstracts).

Stephanov, J. 1961. The Bathonian in the section of the Belogradchik-Gara Oreshets road (North-west Bulgaria). Bulletin of the Geological Institute 9, 337-355, pls 1-7 (in Bulgarian, with Russian and English abstracts).

Stephanov, J.1963. Bathonian ammonites of the superfamily Stephanocerataceae in Bulgaria. Travaux sur la géologie de Bulgarie, Série Paléontologie 5, 167-197 (in Bulgarian, with Russian and English abstracts).

Stephanov, J. 1966. The Middle Jurassic ammonite genus Oecotraustes Waagen. Travaux sur la géologie de Bulgarie, Série Paléontologie 8, 29-69.

Stephanov, J. 1972. Monograph on the Bathonian ammonite genus Siemiradzkia Hyatt, 1900 (nomenclature, taxonomy and phylogeny). Bulletin of the Geological Institute, Series Palaeontology 21, 5-82.

Tchoumatchenco, P.V. 1977. Sur la stratigraphie de brachiopodes du Jurassique moyen dans la région de Belogradchik. Review of the Bulgarian Geological Society 38 (3), 314-319.

Teisseyre, L. 1883. Ein Beitrag zur Kenntnis der Cephalopodenfauna der Ornatenthone in Gouvernement Rjäsan (Russland). Abhandlungen der Kaiserlichen Akademie in Wien, Mathematisch-Naturwissenschaftliche Klasse 88 (1), 538-628.

Thierry, J., Mangold, C., Cariou, E. 1994. Bullatimorphites bullatus forme microconque microstoma (d'Orbigny, 1846). In: Fischer, J.-C. (Ed.), Révision critique de la Paléontologie Française d'Alcide d'Orbigny incluant la réédition de 
l'original. Volume I. Céphalopodes Jurassiques. Muséum national d'histoire naturelle Paris, Masson, Paris, Milan, Barcelone, p. 132, pl. 56, figs 2a-c, 3a, b.

Thierry, J., Cariou, E., Elmi, S., Mangold, C., Marchand, D., Rioult, M. 1997. Callovien. In: Cariou, E., Hantzpergue, P. (Eds), Groupe français d'étude du Jurassique. Biostratigraphie ouest-européen et méditerranéen: zonations parallèles et distribution des invertébrés et microfossiles. Bulletin du Centre de Recherche Elf Exploration Production, Mémoire 17, 63-78.

Tzankov, V., Bončev, E. 1934. Quelques céphalopodes fossiles du Bajocien des environs du village Stratidja, arrondissement d'Eski-Djumaia (Bulgarie du nord). Annuaire de l'Université de Sofia, Faculté de physique et de mathématiques 39 (3), 235-248, pls. 1, 2 (in Bulgarian, with French summary).
Vrăbljanski, B., Minčev, D., Enčeva, M., Stefanov, J., Georgieva, M. 1960. La géologie de la région de Zabărde. Travaux sur la géologie de Bulgarie, Série Stratigraphie et Tectonique 3, 133-160 (in Bulgarian, with Russian and French abstracts).

Waagen, W. 1869. Die Formenreihe des Ammonites subradiatus. Versuch einer paläontologischen Monographie. Geognostisch Paläontologische Beiträge von Doktor Benecke 2 (2), 181-256.

Westermann, G.E.G. 1954. Monographie der Otoitidae (Ammonoidea) Otoites, Trilobiticeras, Itinsaites, Epalxites, Germanites, Masckeites (Pseudotoites, Polyplectites), Normannites. Beihefte zum Geologischen Jahrbuch Hannover 15, 364 pp.

Westermann, G.E.G. (Ed.). 1992. The Jurassic of the CircumPacific. Cambridge University Press, Cambridge, 676 pp. 